\title{
Archaeologia
}

http://journals.cambridge.org/ACH

Additional services for Archaeologia:

Additional services for Archaeologia:

\section{Extracts from the Liberate Rolls, relative to Loans supplied by Italian Merchants to the Kings of England, in the 13th and 14th Centuries; with an introductory Memoir: by Edward A. Bond, Esq. Communicated by Charles George Young, Esq. York Herald, F.S.A.}

\section{Edward A. Bond}

Archaeologia / Volume 28 / Issue 02 / January 1840, pp 207 - 326

DOI: 10.1017/S0261340900000436, Published online: 12 June 2012

Link to this article: http://journals.cambridge.org/abstract S0261340900000436

How to cite this article:

Edward A. Bond (1840). XI. Extracts from the Liberate Rolls, relative to Loans supplied by Italian Merchants to the Kings of England, in the 13th and 14th Centuries; with an introductory Memoir: by Edward A. Bond, Esq. Communicated by Charles George Young, Esq. York Herald, F.S.A.. Archaeologia, 28, pp 207-326 doi:10.1017/S0261340900000436

Request Permissions : $\underline{\text { Click here }}$ 


\section{Extracts from the Liberate Rolls, relative to Loans supplied by Italian Merchants to the Kings of England, in the 13th and 14th Centuries; with an introductory Memoir : by EDWARD A. Bond, Esq. Communicated by Charles George Young, Esq. York Herald, F.S.A.}

Read 11th April, 1839.

Dear Sir, British Museum, March 7, 1839.

THE object of the accompanying Paper is to draw attention to a series of financial transactions which, although intimately connected with our early history, and essential to its faithful development, have hitherto found no place in its pages. Political economy was the science most remote from the speculations of our chroniclers; nor had they, commonly, such an acquaintance with the affairs of the Exchequer as qualified them to transmit to us a correct exposition of the wealth and resources of the country. We are not surprised therefore to find their statements with regard to the revenue inaccurate and meagre; but we are at a loss to account for their silence respecting the Italian money-lenders who, as it will appear, were the main supporters of the King in periods of financial embarrassment, and who, everywhere dispersed throughout the kingdom, must have very beneficially influenced the commercial and even the political condition of the country, by an example of superior enterprise and intelligence, by their connexions with foreign governments, and by the immense capital which they introduced and circulated. This deficiency is supplied by the Public Records; and consequently the evidence which they yield becomes of interest and value. We find in them a vein of history, as it were, hitherto unexplored; and all that I have now attempted, is to present a sample of its produce.

The extracts which I have taken from the Liberate Rolls, consisting of vol. XXVIII. $2 \mathrm{E}$ 
orders upon the Exchequer for repayment of sums which the Italians had advanced to the King on loan, afford a not inaccurate view of the dealings of the government with these foreigners. To make complete collections for the subject it would be necessary to search the Patent Rolls, where the King's letters of obligation are entered for the sums borrowed, and also the accounts of the Keeper of the Wardrobe, by whom the loans were sometimes both negotiated and discharged. I regret that I have not had leisure for the very tedious operation of extracting materials from the former of these classes of records. The Wardrobe books, together with accounts in the Queen's Remembrancer's Office, exclusively relating to the present subject, and of the greatest value in illustrating it, are as yet, unhappily, in that state of unfinished arrangement which renders the use of them inconvenient.

Among the many obligations I owe you, I shall always remember with real gratitude your kind encouragement and advice in an undertaking for which, with too much cause, I feared my incompetency, and the imperfect execution of which, I am well aware, demands the humblest apologies.

Believe me, dear Sir,

Yours, with the greatest sincerity,

EDWARD A. BOND.

Charles George Young, Esq.

York Herald, F.S.A. 


\section{INTRODUCTORY MEMOIR.}

I. The Republics of Italy, during the middle ages, were far advanced Rise of the before the other states of Europe in wealth and civilization. They seem Italian Reto have preserved, through a long period of barbarism, anarchy, and intellectual prostration, the precious germs of political courage and wisdom transmitted to them from the noble republic of which they were the offsets. Rome, no longer a republic, had lost its institutions, its freedom, and its virtue; but its original vigour was inherited by the cities it had propagated. It may be said that, before the irruption of the barbarians, the fields of Italy presented a scene of growing prosperity; for, although at Rome itself all was corruption and decay, around it were springing up in youthful strength and beauty cities which promised to rival its early grandeur. Successive invasions checked their growth, and reduced them to poverty and weakness. Still they preserved vitality, and centuries of warfare and affliction restored them the courage and manly virtues which long previous inactivity had enervated. In the year 951, when Otho I. entered Italy and reduced Berenger II. to vassalage, he found a country covered with cities already surrounding themselves with walls to resist the attacks of the great feudal lords who preyed upon them. Their power and con. sequence rapidly increased. Repeated experience convinced the poor and industrious that they could only be safe by combination; and they sought refuge in those societies where all were equally interested in resisting oppression, and in framing just laws for the welfare of the community. Armed and fortified, they reinforced their population by the multitudes who came to ask the shelter of their walls. Neighbouring towns hastened to place themselves under their protection; and contributed to the territorial property they were fast acquiring. Powerful states were at length established, which secured and constantly added to their strength and riches by the equality of their government, and their mutual league and correspondence. They first emerged from the barbarism which had overspread Europe-they threw enlightenment around them, and with their growth civilization revived throughout the world. 
The city of Venice.

Genoa and Pisa.

But the circumstance which most deserves attention from its commercial consequences was the rise of the city of Venice, to which the misfortunes of Italy gave birth. Early in the fifth century, the most wealthy of the inhabitants took refuge from the persecution of barbarian hordes in the marshes at the extremity of the Adriatic; where the nature of the situation afforded them shelter. The city which sprung up there became an asylum for the wealthy and intelligent, who, long prevented from acquiring property in land by the predatory bands which infested the country, were constrained to employ their energies in commerce and navigation. Their geographical position, as well as political circumstances, drew them to the Levant. The connexion between Italy and the Greek empire had never been entirely broken, and now it was destined to be renewed and confirmed. Its commerce We find traces of the Venetians in Constantinople and in Syria throughout
with Asia. the ninth and tenth centuries, and in the eleventh a new stimulus was to be given to their activity, and a wider scope to its exertion, by the Crusades. The pilgrims, who in large numbers visited Jerusalem, had already contributed to give an eastern direction to their commerce : but now armies were to be transported and supplied with equipments and provisions. At the same time the increasing dangers to which the Greek Empire was exposed by the fermentation excited by these religious expeditions, and their own conscious weakness, urged the Emperors of Constantinople to draw closer the alliance with so powerful a people. Grants of privileges followed each other in quick succession, and every sacrifice was made to attach them to the Emperor's interest ; whilst the Venetians were sufficiently clearsighted to appreciate and profit by the advantages of their position. At the commencement of the twelfth century they were enjoying a lucrative commerce throughout the Grecian Empire, were protected to a degree beyond the native merchants by privileges almost unlimited, and were in possession of extensive factories in Constantinople, in Syria, and in Palestine. Quickly following in the steps of the Venetians, the Genoese and Pisans shared these advantages. They were hardly less favoured at Constantinople, and in Palestine they obtained equal liberties. It may be attributed to the Crusades that, in the course of one century, merchants, who before had trembled to leave the coasts of their own country, and who abroad were oppressed with arbitrary imposts and extortion, and harassed with every variety 
of danger, now found on foreign shores splendid establishments of their fellow-citizens, enjoying undisturbed their own manners, laws, and customs.a

The progress of the inland cities of Italy was less rapid. They were more The inland exposed to oppression and pillage from the hordes of Goths, Lombards, and cities. Franks, who successively laid waste the country. In the tenth century, when the Venetians were engaged in active trade in the Levant, Milan, Pavia, and the cities of Tuscany were but beginning to defend themselves with walls and to establish governments. But, from the time when the industry of the inhabitants was thus protected, they advanced quickly and with certainty. The superior power and the jealousy of the Venetians deterred them from entering early into the trade with the East. Confined, as they at first were, to their own plains, they possessed themselves of large territorial property, which they cultivated with care and skill; and their activity was employed in forming canals and facilitating communication throughout their country. As their capital increased, they used it in freighting the ships of the Venetians, who naturally became carriers in the trade with a country where they enjoyed such exclusive privileges, and in dispersing through their own country the merchandize imported in ships of Venice, Genoa, and Pisa. Gradually extending the field of their commerce and enterprise, they found encouragement in the northern states of Europe, which had not yet reached an equal height of civilization and prosperity. With a superiority of wealth, and the advantages afforded by a government and laws especially founded on mercantile interests, the Italians were not slow in obtaining a principal share in the commerce of the continent. Bruges was the market to which they brought the rich produce of the East; thence to be spread over Germany, the Netherlands, France, and England; and they received in exchange, and at an enormous profit, the gold and silver, the wine, wool, and manufactures of those countries. At a later period, in the eighteenth year of Edward III. we find the Commons of England representing to the King that, whereas the staple of wool had been fixed at Bruges, the merchants of that town and of Gaunt and Ypres had ordered that no wools should be sold to strangers, or carried out of Flanders; thus preventing the Italians from dispersing that article through

a Heeren, Essai sur l'influence des Croisades, p. 347. 
Europe, as they had been wont to do, and causing a depreciation in the value of wool.a

Origin of the occupation of the Italians as money. lenders in Europe.

The Pope's bankers and collectors.

The Crusades.
II. But, while thus trafficking in all parts of the world, the merchants of Italy early assumed the character of bankers and money-lenders by which they subsequently became distinguished. The origin of their dealings in this capacity is distinctly to be traced to their connexion with the court of Rome, as its agents and merchants in every part of Christian Europe. The authority which the Pope exercised in ecclesiastical affairs was not confined to regulating creeds, or preserving church discipline, or even to an interference in the patronage of benefices. As time and superstition, and an unchanging policy perseveringly pursued, steadily and surely augmented his power, he advanced his claims to such a portion of the revenues of the clergy as temporal princes were wont to take from their subjects. Frequent crusades against heretics, and the costs of defending the Church, as well against its own rebellious children as those its avowed enemies, afforded plausible pretexts for these encroachments. Moderate contributions were at first yielded with enthusiastic devotion in a holy cause; but the exactions were repeated till they grew to be sanctioned by custom. Italian merchants were the agents employed to collect the revenues thus arising from every part of the continent. The practice of remitting sums of considerable magnitude to distant places taught them gradually to improve their system of exchange, and they soon rendered it superior to that in use among the less experienced merchants of other countries. At the same time they found innumerable opportunities of accommodating individuals with loans, for the payment of such debts as, in their capacity of farmers and collectors of the Pope's revenues, they required of them: and thus they were led to that system of money-lending which became the chief feature of their commerce. But, to explain the rapidity with which it attained maturity, we must again refer to those religious expeditions which drew Europe from its home, and gave birth to a new series of political and commercial events.

The necessities of the Crusaders, in the eleventh and twelfth centuries, manifestly gave the greatest encouragement to the practice of usury. The 
drain of money, occasioned by the anxiety of military leaders and their followers to convert their property into a form convenient for the exigencies of their expedition, so much enhanced the value of specie as to render such traffic irresistibly lucrative. The Venetians, Pisans, and Genoese were sufficiently occupied in supplying the adventurers with ships provisioned for their use. But the commercial position of the Lombards and Tuscans enabled them to undertake with the highest advantage the department of facilitating exchanges of property, providing personal equipments, and supplying the ready money indispensable in the circumstances of the Crusaders. The persecution of the Jews, and their inferiority in commercial privilege, rendered them unequal competitors in the trade. Every year an increasing scarcity of coin must have advanced the rate of interest; and, considering how universal at the same moment was the demand for money, and how long it continued, and, moreover, that the sums so drafted were squandered in transactions from which no gainful return was sought or expected, we shall easily comprehend the zeal with which the Italians engaged in the business of money-lenders. But, by their eagerness in pressing these advantages, they brought themselves into ill-odour with all classes of people. Numerous were the censures passed against them by ecclesiastical councils, and the laws of all nations condemned their occupation as heretical.

III. The restrictions under which commerce was placed in England, and Introduction the national jealousy of foreigners, seem for some time to have acted as of Italian effectual obstacles to the introduction of the Italians into this country; into England. and, in the meantime, the Jews monopolised the capital of the kingdom, and were frequently the King's agents in pecuniary transactions. But, as in the Employed as case of other nations, the dependence of the church upon the see of Rome the Pope's was the means of procuring them a footing in our island.

The Pope's authority was almost paramount in this kingdom during the reigns of John and Henry III. And to this period, (when, under the name of Caursini, ${ }^{\mathrm{b}}$ we find them very harshly spoken of by Matthew

b I cannot offer any conjectures as to the etymology of this word, but must beg leave to refer to Muratori, Antiq. Ital. Med. Æv. Dissert. xvi. and to Ducange, sub voce; where the origin of the 
Paris, as usurers and instruments of the Pope's extortion,) may be attributed the commencement of that system of money-transactions which the Italians exercised in England with enormous profit, but which at length brought ruin upon them in the middle of the reign of Edward III.

The merchants whom his Holiness thus employed as his agents in England, were citizens of Sienna, Lucca, and Florence, and principally of Sienna. They generally were members of established companies, trading in common. But, in the instances where I have found them mentioned, the names of the principals of the firms are not always very clearly distinguished. In a letter in the Register of Reading Abbey, preserved in the British Museum, dated in an early year of Edward I. there is notice of four companies of merchants of Sienna, at that time acting here under the title of "Campsores Papæ;" but the names of the companies are not expressed. Other companies probably were at the same time employed by the Pope in this country, in a similar capacity. And we shall hardly wonder that his agents were so numerous, when we consider the largeness of the revenues that were to be collected. In addition to the annual census and the first fruits, the profits of a tenth or the moiety of a tenth of ecclesiastical property were to be remitted almost yearly. From the reign of John down to about the eighth

term (attributed by one to the town of Cahors, and by the other to the name of an Italian family) is fully discussed, I have met with only two unpublished instances of its use. The first, in the title to an instrument inserted in the Register of Reading Abbey, MS. Harl. 1708, p. 39. It is as follows :

"Littera acquietantiæ contra Cauercinos de omnibus litteris obligatoriis aliquod debitum continentibus."

Then follows the instrument :-“ Anno Domini M $^{\circ} \mathrm{Cc}$. octogesimo sexto, die Jovis proximo post festum S. Eduuardi Regis, frater Willielmus de Suttone, camerarius Rading', et Salymb'n Alex', civis et mercator Senensis, invicem computarunt de omnimodis debitis in quibus Abbas et conventus Radyng' eidem Salymb'n et sociis suis quibuscumque, de societate sua Sen', aliqualiter tenebantur, usque ad diem prædictum," \&c.

The second instance occurs in an account of the burser of the abbey of Dore, for the year 1274 (in the Queen's Remembrancer's Office); where it is used in the title to a small division of the account, which relates to repayment of money borrowed of apparently Italian merchants. The title and entries are as follow:

“Debitum Cauersor'-Hugoni Bonaventure occclxxiiji. vjs. viijd. Claro Sagin ...clx......ijd. excepto stagiamento anni præsentis. 
year of Edward III. the clergy were perpetually subject to these impositions. It was not unusual for the Pope to purchase the King's connivance, by allowing him to participate in the proceeds. He would impose a tax of a tenth upon the clergy for four, five, or six consecutive years, and, by offering the King a moiety, he obtained the authority of his countenance in enforcing the payment. There was continual occupation therefore for the bankers who were sent to gather in the Papal revenue; and as Ireland and, in a less degree, Scotland, were also contributors to these holy funds, a numerous body of agents was required. They could hardly have been introduced into the kingdom under better auspices. The business they were charged with brought them into continual communication with the Religious Houses, who engrossed a large share of the national wealth-a connexion Their dealof which they were not slow to avail themselves, in their character of mer- $\mathrm{ings}$ with chants and money-lenders. Often, when persecuted by the Pope for sums Houses. which he exacted from them, convents were obliged to have recourse to the very merchants who were the instruments of his extortion, in order to satisfy the demands he pressed upon them. Opportunities of affording such accommodation necessarily multiplied in times when the revenues of the clergy were frequently drawn upon by both their temporal and spiritual superiors; and the operations of the Italian moneylenders became more and more extended. The influence of the example of these religious communities, and the name of the Pope, whose merchants the Italians professed to be, reconciled the minds of men to usurious practices, obnoxious to the prejudices of the times, and saved them from a persecution they would otherwise hardly have avoided: and subsequently, in their dealings with the King, whenever they were in apprehension from his displeasure or his avarice, they sought in the Pope a mediator and protector, who exerted his interest in their favour. Instances occur in the Fœdera. Two letters may be cited of Pope Boniface, dated in the twenty-seventh and twenty-ninth years of Edward I. In the first of these he intercedes with the King in behalf of the Spini, who had complained of being harassed by the King's officers, employed in obtaining a loan of large amount from the companies of Italian merchants then in England. The Pope urges in their behalf that their funds are exhausted by considerable sums which they have lent in VOL. XXVIII. 


\section{6}

\section{Extracts relative to Loans supplied by Italian Merchants}

divers quarters, both in and out of Italy ; moreover, that the King is already engaged to them for large amounts, which they have at other times advanced to him, and for which they have assignments on his revenue. ${ }^{c}$ In the second letter his Holiness again intercedes in behalf of the same company, who, in consequence of an act of homicide committed by one of their number in a broil in London, had all been apprehended and imprisoned, and their goods arrested. ${ }^{d}$

Pulitical con- Our connexion with the court of Rome acted in another way in introducnexion of

England with

the court of

Rome. ing the Italian merchants to the notice of the King and his subjects. The Pope's interference in the affairs of the country caused his court to be thronged with royal ambassadors and messengers. It would have been hazardous and almost impracticable to carry with them the money which it was generally found expedient to expend there in large amounts; for the coin

Letters of credit. was bulky, the journey a long one, and risks plentiful. In such circumstances, the wealthy merchants abounding in those parts were commonly resorted to and they advanced the required sums upon letters of credit from the King, with which the ambassador was provided. Documents of this description are of frequent occurrence in the Charter and Patent Rolls of the earliest date; and they deserve attention both as illustrating this point of our subject, and as approaching so nearly in their character to Bills of Exchange, the history of the origin of which is still obscure. They are referred"to in letters of obligation entered on the Charter Roll of the first of John, by which the King promises to pay to merchants of Piacenza a sum of money which they had advanced to ambassadors at the court of Rome, by command of King Richard I. It is in the following form :

" Johannes, Dei gratia, Rex, etc. dilectis amicis suis Speren', Barageton' et eorum sociis, mercatoribus Placentinis, salutem. Sciatis quod vobis solvere volumus duo milia marcarum et cxxv marcas, quas, pro amore bonæ memoriæ Regis Ricardi fratris nostri, et ex mandato ipsius, mutuo concessistis Willielmo Andegavensi et R. Bangorensi episcopis, et Stephano Ridel, ad negotium karissimi nepotis nostri illustris Regis Othonis in curia Romana faciendum.' Ideoque vobis præsentibus litteris in tantam pecuniam nos obligamus ; promittentes quod, ad proximum festum S. Michaelis post corona- 
tionem nostram, vobis vel certo nuntio vestro præsentes litteras afferenti et exhibenti, sexcentas et viginti quinque marcas apud scaccarium nostrum in Anglia solvi faciemus, et ad proximum sequens Pascha quingentas marcas ibidem, et postmodum in sequenti festo $\mathrm{S}$. Michaelis quingentas marcas ibidem, et ad proximum sequens Pascha quingentas marcas similiter ad scaccarium nostrum in Anglia solvi faciemus vobis vel certo nuntio vestro, litteras obligationis nostræ exhibenti. Et, nibilominus, ita vobis in gratiarum actione pro benigna expectatione vestra, favente Domino, respondebimus, quod expectatio vestra vobis non videbitur onerosa. Teste me ipso, apud Rothomagum, xxv. die Augusti." e

The letters of credit are usually in the form of the following example; the date of which is the second of John :

" Johannes, Dei gratia, etc. universis mercatoribus, etc. Noverit universitas vestra quod nos latores præsentium, Hugonem de Feritate et Robertum de Sablenc', pro negotiis nostris promovendis ad Romanam curiam destinamus, et mercatoribus a quibus pecuniam usque ad $\mathrm{D}$. marcas argenti pro ipsis negotiis promovendis mutuo acceperint, ipsam pecuniam persolvere tenebimur : et nos per præsentes litteras principales super hoc constituimus debitores, et, termino statuto, secundum conventionem inter prædictos clericos nostros et mercatores factam, illis qui præsentes litteras nobis vel mandato nostro reddent, una cum litteris prædictorum clericorum patentibus summam pecuniæ mutuo acceptæ protestantibus, pecuniam ex integro faciemus persolvi. Teste me ipso, apud Fissam, vi die Januarii." $f$

It is unnecessary to present the long series of similar instruments which might be collected from the pages of the printed Patent and Charter Rolls of the reign of John: it is sufficient to refer to them. $\mathrm{s}$ From the frequency of their occurrence, however, at this period, we can have no difficulty in believing that their utility had for some time previously been experienced. We have quoted from the earliest of the Chancery Rolls, and, had those records commenced at a more remote date, they would doubtless have yielded earlier instances. It appears that these letters of credit were sometimes issued in the King's name, for the benefit of his subjects ;

e Rot. Chart. p. 31.

f Rot. Pat. p. 4.

g Rot. Chart. pp. 97, 98, 99. Rot. Pat. pp. 5, 6, 9, 10, 39, 65, 67, 107, 182. 
who thus were enabled to raise loans upon his security. The letters quoted above were issued for such a purpose, as appears by the following:

"Universis ad quos præsens scriptum pervenerit Radulphus vicecomes Sanctæ Susannæ, etc. Noveritis dominum meum J. Regem Angliæ mihi et Willielmo fratri meo suas litteras concessisse, de pecunia mutuo accipienda sub nomine ipsius a nuntiis meis et fratris mei, quos idem Rex suos vocat, ad Romanam curiam destinatis, usque ad $D$. marcas argenti, si eis opus fuerit. Inde est quod, si forte præfati nuntii per prædictas litteras domini Regis aliquam mutuo pecuniam a quibuscumque mercatoribus acceperint, ego pro eadem pecunia me et totam terram meam domino Regi obligo; promittens me eam, secundum conventionem quæ inde facta fuerit, sine omni molestatione domini Regis, statutis terminis soluturum : et dominum Regem indempnem conservabo." $\mathrm{h}$

" Universis, etc. Willielmus de Rupibus, etc. Noveritis quod dilectus meus R. vicecomes S. Susannæ a venerabili domino meo J. Rege Angliæ litteras impetravit, pro pecunia mutuo accipienda usque ad $\mathrm{D}$. marcas argenti a nuntiis ipsius et fratris sui, viz. H. de Feritate et R. de Sablenc', ad Romanam curiam destinatis. Inde est quod ego, pro quantacumque pecunia ab eisdem nuntiis usque ad dictam quantitatem, nomine domini Regis, a quibuscumque mercatoribus recepta, me domino Regi fidejussorem constituo, obligo, et principalem constituo debitorem. Ita quod, si prædictus vicecomes domino Regi non satisfecerit, ego satisfaciam, et dominum Regem indempnem conservabo." $i$

Instances of this mode of making the royal credit available are not sufficiently numerous to mark it as a custom, although the accommodation which it secured to individuals encourages the conjecture that the practice was not infrequent.

Loans to attorneys of parties in suits, in the court of Rome.
It was not solely to supply the necessities of the King's messengers at Rome that the funds of Italian bankers were in requisition. The dependence of the English Church upon the see of Rome brought ecclesiastical causes from this country perpetually before the Pope; and his court was ever filled with the attornies of parties in suits, each struggling to win an i Ibid. 
advantage over his adversary by finesse and bribery. The money thus expended was advanced by merchants there; and we have evidence to this effect in the Patent Roll of the seventh of John :

"Rex omnibus mercatoribus ad quos, etc. Sciatis quod concessimus et volumus quod pecunia quam Walterus et Adam et magister Martinus, nuntii Glastoniensis ecclesiæ, vel duo eorum, mutuo ceperint de mercatoribus, usque ad summam septingentarum marcarum, pro negotiis ecclesiæ pro quibus ad Sedem Apostolicam missi sunt, persolvatur de rebus et possessionibus prioris et conventus Glastoniæ. Et concedimus quod mercatores qui prædictis nuntiis prædictum mutuum fecerint, vel eorumdem mercatorum nuntii, qui cum præsentibus litteris et litteris prædictorum nuntiorum Glastoniensium mutuum illud testantibus in Angliam venerint pro pecunia sua recipienda, salvum et securum conductum in veniendo et redeundo habeant. Et in hujus rei, etc. Teste me ipso, apud Westm. vii. die Dec. anno, etc. vii." $\mathrm{k}$

A letter entered in the Patent Roll of the third of John shews that this method of obtaining money was resorted to for purposes of a political character :

"Rex, etc. dilectis suis Romæ, Tusciæ, Italiæ mercatoribus, etc. Denuntiamus vobis ne Priori de Sagien' et sociis suis aliquam pecuniam credatis super litteras capituli sui. Ille enim et quidam complices sui contra nos et dignitatem nostram laborant. Sciatis enim quod, si quam pecuniam illis crederetis, de pecunia terræ nostræ non reddetur. Teste me ipso, apud Rothomagum, xxx. die Martii." 1

IV. Before the close of the reign of Henry III. the Italians had gained a Operations firm footing in England, not merely as the Pope's servants but as merchants of the ltalians and money-lenders. The commercial state of the country at that period in England, offered many advantages to traders who, like the Italians, were in communi- and moneycation with agents and partners in all parts of the world, and had large among the capital at command. Specie was then scarce, a paper currency a thing un- jects. heard of, and the convenience of exchange by bills was probably as yet only practised by the Italians themselves. The restrictions and arbitrary regulations with which trade was shackled, and perhaps the general manner and 
habits of life, had hitherto much impeded commercial prosperity. The wealth of the country was in the hands of the large proprietors of land, and the revenues of the crown were principally derived from feudal charges to which territorial possessions were subject. Rolls of the collection of subsidies, remaining in the Exchequer, shew how insignificant a portion of the public taxes was paid by the class of merchants and burgesses. We were almost destitute of manufactures. Wool, the staple commodity of the country, was ex changed in the ports of France and the Low Countries for bullion, wine, and merchandise of other description. The state of the inland trade of the country was deplorable. The several provinces of the kingdom, by the effect of feudal government and the backwardness of civilization, were almost as effectually separated as if divided by mountains. The produce of each district was exchanged by actual barter among the inhabitants, at the periodical fairs in the neighbourhood. What foreign commodities were in use, were bought at the large fairs of Boston, Winchester, and Bristol; and only partially dispersed through the kingdom by travelling merchants little above the rank of modern pedlars. The commercial wealth of the country was collected in a few towns and cities, such as London, Bristol, Winchester, Lincoln, Boston, York, and Hull ; and the difficulties and dangers of carriage confined the advantages of their prosperity to the immediate vicinity. The arrival of the Italians at such a time was extremely opportune. The natural produce of the country was rich and abundant; but it required to be circulated, and, in doing this, the activity and means of the foreigners were most beneficially exercised. They spread themselves over the country ; they filled the fair of Boston and others with foreign goods of their own importation; and their superior opportunities of disposing of wool, enabled them to bid high for that commodity of which a large proportion passed through their hands. Some estimate of the extent to which they carried this branch of their traffic may be formed from the contents of a bundle of documents which I have seen amongst the Queen's Remembrancer's Records, consisting of returns, from ten different companies of Italian merchants in England, of the quantity of wool in their possession on a certain day in the twenty-second year of Edward the First. The King was then at war with 
France; and he had issued commands for the arrest of all wool, wool-fells, and hides, in whosesoever hands they might be found. They were to be retained in the custody of the King's officers, in order to prevent the possibility of their being exported into the dominions of the French King. The returns alluded to are made by the Italians themselves. The companies are distinguished by the following names: "La compaignie de sire Barde Frescobald de Florenze, Neire." m "La compaignie del Cercle Blanc." " La compaignie du Cercle Neyr de Florenze." "La compaignie de Barde de Florenze." "Societas Ricardorum de Lucca." " La compaignie de Pouche de Florenze." "La compaignie de sire Jon de Friscobald de Florence, Blaunk." "La compaignie de Mozze de Florenze." "La compaignie de Spine de Florenze." "La compaignie de Bestre de Louck [Lucca]." The total number of sacks of wool which they acknowledge to have in their possession, is two thousand three hundred and eighty. By far the greater part is stated to have been bought of religious houses : indeed many of the companies return as having received only from them. The original documents contain statements of the conditions and circumstances of the purchases; by which it appears that many of the religious houses were under engagements to deliver all their wool, of one or more year's growth, to some one of the companies, at a price previously stipulated. The Abbey of Waverley, for instance, was bound to deliver all its wool to the Frescobaldi Neri of Florence, at Kingston-upon-Thames, on the feast of St. John, and they were to receive twenty marks for every sack of good wool, and fifteen marks for each sack of middle value. ${ }^{n}$ Allowing the smaller sum to

m The terms "black" and "white" have reference to the two parties, distinguished as "Bianchi" and "Neri," which at this period filled the cities of Pistoia, Florence, and Lucca, with tumult and bloodshed.

n The following is a copy of the entry alluded to. It is the first in the return headed thrus: "Cestes sunt totes les manieres de leines ke la compaignie sire Barde Frescobald de Florenze, Neire, avera en le reaume Dengleterre, lan de grace $m$ cc iiijxx. et quatorze." The entry is in these words : "Sussex-Del abbe et covent de Waverle del ordre de Cisteus, tote lor leine, a liverer a Kyngeston' sor Tamise a la Sejnt Johan : mes quans de sacs nus ne savom. Autan aveient il de bone laine xij sacs de leyne et viij peres, et de mesne leine et de lokes tries iij sacs. Si nus coste 
have been the price at which the whole number of 2,380 sacks was purchased, that alone would prove them to have had capital thus employed in England only to the amount of $23,800 l$, a large sum according to its then value. But it appears that the returns were incomplete. They were made by members resident in London, and to each a note is added to this effect : "We have other wools collected in divers parts of the country, which, we believe, have been arrested ; but we cannot ascertain the number of sacks, until our partners, who have the business in charge, have returned to London." It is probable therefore that their capital, in this single branch of traffic in England, was not less than 30,000l. And, when we consider that they were at the same time advancing loans of large amount both to the King and private individuals, and, also, were exercising other branches of general commerce, we cannot but think highly of their wealth and resources.

It is sufficient to have spoken thus generally of the commerce of the Italians, which is distinct from the present subject. Nor do I dwell upon their dealings in the capacity of money-lenders to the King's subjects ; for information with respect to which I refer to the Memoranda Rolls, where, under the title "Recognitiones," are numerous entries to shew how actively they pursued this branch of trade. Of these Rolls the only numbers which I have had the opportunity of examining are those of the eighth, sixteenth, and seventeenth years of Edward the First : in each of which the memoranda of acknowledgements of debt from religious houses and private persons to Italian merchants are frequent. The debtor usually pledges all his lands and property to the observance of the appointed term of payment, and security is given to the creditor by the recognition of debt thus solemnly recorded in the Exchequer. ${ }^{\circ}$

chescun sac de la bone leine $\mathrm{xx}$ mars, et chescun sac de moiene leine et de lokes tries $\mathrm{xv}$ mars. Et si nus doivent il rebatre des arres c. s. et nos lor avoms onquore paie sor. la leine de cest an lxiij]i. et iijjs. Si kil amonte ceo kil unt eu sor lor leine de cest an, c et ij. m. iiij s.

Et le apariller de ceste leine nos couste a cest an $x l^{s}$."

- I subjoin the following as a specimen of these instruments. It is extracted from a Memoranda Roll of the year 16 Edw. I. preserved in the Queen's Remembrancer's Office : 
V. The Italians had not been long in England before the political import- They attract ance of their riches and enterprise was evinced. They could not exercise the attention any commercial dealings unobserved by the King, who had an arbitrary ment. authority in the regulation of trade. The nature of the government, too, speedily brought them under his notice. Upon entering the kingdom they were obliged to obtain the royal protection, and permission to carry on their traffic; and, while so engaged in the various provinces of the empire, they were always under the eye of government, by means of the Sheriffs and other officers, who were brought periodically to the Exchequer to discharge their accounts, and there came into immediate communication with the chief ministers of state. The wealth of the Italians and their skill in money business were not long unnoticed, and the wants of government very soon introduced them to the officers of the Exchequer.

A great defect in financial management in England, at the period No regulated under consideration, was the absence of an established system of system of raising money upon credit for public purposes. This evil had been in some practised by degree obviated by the first Kings of the Norman line, who hoarded the Exchelarge sums in their treasury to meet unlooked for exigencies. But such a system of economy was far easier to practise at a time when the foreign dominions of our kings were extensive, and as yet in their secure possession, than at a subsequent period. The first five sovereigns after the conquest passed the greater portion of their reigns upon the con-

" Recognitio fratris Thoma Abbatis deRivall, facta xviij die Octolris, anno regni Regis Edwardi wrj".

"Idem venit coram Baronibus et recognovit pro se, conventı suo et ecclesiæ sua, et pro abbatibus successoribus domus suæ, se teneri Guidoni Dananc', Jacobo de Fronte, Renerio Jacobi, de societate domini Guidonis de Friscobald', et aliis sociis suis, civibus et mercatoribus Florentinis, in ducentis et quinquaginta marcis sterlingorum. De quibus solvet eisdem quinquaginta marcas ad quindenam Nativitatis S. Johannis Baptistæ proximo futuram, apud S. Botulphum; et sic de anno in annum quinquaginta marcas ad eosdem terminum et locum, quousque de prædictis ducentis et quinquaginta marcis plenarie fuerit satisfactum. Et, nisi fecerit, concessit pro se et conventu suo, et pro abbatibus successoribus domus suæ, quod Barones de Scaccario de terris, tenementis, bonis et catallis suis, ad quorumcumque manus devenerint, prædictos denarios fieri faciant."

VOL. XXVIII. 
tinent; and a large proportion of their expenses must have been defrayed out of the revenues of their provinces there. But from the reign of Richard the First that prosperous state of things underwent a change. Their foreign possessions were wrested from the hands of our Kings, or what little they retained became a source of loss instead of profit. In the reign of Henry the Third, the royal revenues were inadequate to the usual charges of the household and of government; and the incessant wars in which Edward the First was engaged drove him to numberless expedients for supplying his immediate necessities. The ordinary revenue of the Crown was about thirty thousand pounds. When political circumstances required an extraordinary expenditure, the King demanded a subsidy of his Parliament, which he assembled for the purpose; and if, as was not invariably the case, he was so fortunate as to obtain it, the addition to his income for the year was about twenty thousand pounds. But the collection of the tax was slow, and, when circumstances made immediate outlays necessary, the means resorted to for obtaining a present supply was to call upon sheriffs to pay into the Exchequer whatever sums might be in their hands, before the proper day of account, or to beg of individual nobles, but more especially of the religious houses, small loans, which they advanced with reluctance. The native merchants were not yet wealthy enough to afford assistance by advancing the funds required. Perhaps too they would be cautious of trusting their riches with one from whom they had no certain means of recovering them; and experience had not yet familiarised them with such transactions. Moreover they were little tempted to undertake such engagements by any prospect of gain; for the practice of taking interest on money was considered heretical, and the negotiation of a loan would have been upon the principle of restoring the mere amount received at a stipulated term of payment. The Jews alone followed the occupation

The Jews. of money-lenders. But their dealings were among private persons; and the mode by which they contributed to the King's revenue was by the extortion which was practised on them. Habitual oppression and persecution must have prevented their acquiring very considerable property, and their wealth seems to have been over-estimated. They were wholly at the mercy of the 
King, to whom they stood in the relation of slaves or cattle rather than of subjects; and the minute surveillance under which they were placed renders the popular stories of their concealed treasure somewhat improbable. Error has arisen from paying too much regard to instances of enormous talliages upon the community, or of heavy fines sometimes imposed upon or offered by individual Jews. But it should be recollected that of such talliages and fines in the generality of cases a portion only, and sometimes a very small portion, was actually paid. A large amercement might be charged upon a Jew, not in expectation of his ability to pay it, but to obtain a pretext, from his failure, for seizing whatever property he possessed. A loose estimate of the extent of their wealth may be calculated from a record which I have seen in the Pell Office; by which it appears that the receipts from a talliage upon Jews of the third of their property, between Michaelmas and the tenth of March in the year 2 Edward I, amounted to 1,232l. 15s. 8d., and the entire collection did not probably exceed $2,000 \mathrm{l}$. It was not, then, to any class of his native subjects that a prince like Edward the First, who was perpetually engaged in political transactions which rendered a command of ready money indispensable, could have had recourse with the certainty of assistance. But in the Italian merchants, who were now spread in numbers over the kingdom, he found men qualified by their intelligence and enterprise, and by their inexhaustible resources, to furnish him with the immediate supplies he needed, and to devise methods for enlarging the royal revenues : and the annexed extracts shew, partially, to what extent both he and his predecessor Henry the Third, and also his successors Edward the Second and Third, availed themselves of the assistance of these foreigners.

VI. It is an indication of the utter ignorance of the principles of System of commerce, prevalent at the period to which the present memoir has re- negotiating ference, that the receipt of interest for money lent was prohibited as with the usurious, and those who followed such practices were liable to be treated as heretics. Jews alone were licensed usurers, or, at least, were able to pro- General laws cure the privilege; and the King participated in their gains, however much rest, and he condemned the traffic among his Christian subjects. $p$ But a prohibition modes of

- See Tovey's Anglia Judaica, p. 121. In addition to the evidence le quotes to prove that the private parties. 
so impolitic and inconvenient was necessarily evaded. There was nothing to prevent money-lenders from discounting upon the sum advanced, and thus securing a premium. Among the petitions to Parliament in the sixth year of Edward the First, we find an instance of a transaction of this nature. A convent brings a charge of usury against merchants of Florence upon the following case. They had advanced the abbot of the house a sum of three hundred marks upon his bond for that amount, and they had afterwards received from him a bill for forty-two sacks of wool "de avantagio," which, in the words of the original petition, "videtur esse usum per usum pro mutuo scripto dictarum trescentarum marcarum; in qua littera signata dictus abbas confitetur se pro eisdem quadraginta duobus saccis lanæ plenariam pacationem recepisse, cum tamen nullum denarium pro prædictis quadraginta duobus saccis lanæ recepisset ab eisdem." q Another mode of making profit by loans was by stipulating for repayment in goods. The records from the Queen's Remembrancer's Office, before quoted, shew to what an extent this practice prevailed. Again, in lending to private parties, moneylenders aroided the charge of usury by making the loan gratuitous for a certain period; but upon the expiration of the specified term, if the debt remained

Jews were licensed usurers, I may refer to the printed Fine and Oblata Rolls, where instances are met with of the King's having taken a portion of their gains according to an obviously regulated system. However, it is not absolutely proved that all Jews might legally practise usury. Tovey cites an instrument from the Close Roll of the thirty-second of Henry III. to shew that forty-five per cent. or, as the record expresses it, twopence every week for twenty shillings, was allowed to be taken for interest by Jews at that time. I shall perhaps be excused for giving the copy of a bond, existing among the miscellaneous charters in the British Museum, where precisely the same rate of interest is secured to a Jew usurer: "Sciant præsentes et futuri quod ego Hugo de Nevile, miles, dominus de Cadeneye de comitatu Lincolniæ, debeo Bonami generi Jocei, Judæo Eboracensi, novies viginti libras sterlingorum; solvendum sexaginta libras ad quindenam Pentecostes anno regni Regis Henrici filii Regis Johannis quinquagesimo sexto; sexaginta libras ad quindenam S. Martini in hieme proximo sequentem; et ad Pentecosten, scilicet, ad quindenam Pentecostes proximo sequentem, sexaginta libras. Et, nisi tunc reddidero, dabo ei pro qualibet libra qualibet septimana post terminum elapsum duos denarios de lucro, quamdiu istud debitum per gratum ejus tenuero. Et ideo invadiavi ei omnes terras meas, redditus et catalla mea, ubicumque fuerint, donec dicta debitum et lucrum reddidero. Et hoc affidavi et sigillo meo confirmavi. Actum die Dominica proxima post festum S. Martini in hyeme, anmo regni Regis prædicti quinquagesimo sexto."

q Rot. Parl. vol. i. p. 1. 
unpaid, they were to receive compensation for the losses accruing to them from the breach of agreement. This compensation was either a fixed sum, of large amount, previously determined; or receipt of interest at a rate agreed upon in the bond; or it consisted in both damages and interest, adjusted by an estimate of the merchants themselves, to be received without question. Finally, the debtor pledged his land and property to the faithful observance of the conditions of the obligation. Safe under the title of the Pope's servants, they were enabled to urge the fulfilment of these contracts; which, if necessary, the Pope would enforce by threats of excommunication : and subsequently their services to the King secured them his countenance and assistance. As an example of the precautions which were taken to fortify these engagements against the possibility of evasion, I subjoin a copy of a bond taken from a register of Glastonbury Abbey; in which that convent acknowledges the receipt of a loan of $1,750 l$. sterling, from merchants of Lucca..$^{\mathbf{r}}$ Payment by instalments at five specified terms is promised, under penalty of refunding all losses, costs, and interest, according to the assessment of their creditors. They renounce all subterfuges, and for the performance of the conditions they submit themselves to ecclesiastical censure and coercion, and grant the merchants power to distrain their goods.

r "Universis præsentes litteras inspecturis frater Johannes, permissione divina, Abbas monasterii de Glastonia, et ejusdem loci totus conventus, ordinis S. Benedicti, Bathonensis et Wellensis diocesis, salutem in Domino sempiternam. Noverit universitas vestra quod nos recognoscimus et in verita'e confitemur nos, monasterium nostrum et successores nostros, ex causa veri et puri mutui quod, pro nostris et monasterii nostri utilibus et necessariis negotiis promovendis et expediendis, recepimus, teneri et obligatos esse domino Baruncino Walteri et Brunetto filio ejus, civibus et mercatoribus Lucanensibus, et utrique eorum insolidum, in mille septingentis et quinquaginta libris bonorum novorum et legalium sterlingorum. Quas quidem mille septingentas et quinquaginta libras solempni stipulatione et bona fide, et in verbo veritatis, promittimus eisdem mercatoribus vel uni eorum, aut utriusque eorum vel alterius eorum hæredibus sive attornatis seu procuratoribus, reddere, solvere et restituere, Londoniæ, in quinque solutionibus, terminis subscriptis ; videlicit, quinquaginta libras sterlingorum in festo Pentecostes, currente anno Domini millesimo ducentesimo nonagesimo quarto; et quingentas libras in festo S. Martini de mense Novembris, anno eodem; et ducentas quinquaginta libras in festo Pentecostes, currente anno Domini millesimo ducentesimo nonagesimo quinto; et ducentas quinquaginta libras in dicto festo S. Martini ejusdem anni; 

Profits upon - Interest was very rarely promised for loans which the King received of
loans. Premiums. the Italians. An exact equivalent seems to have been returned for the Interest. amount borrowed, and the usual remuneration was a premium, sometimes conditioned for at the time, but, apparently, more often voluntarily con-

et ducentas quinquaginta libras in festo Pentecostes, currente anno Domini millesimo ducentesimo uonagesimo sexto. Quod si, quod absit! contingat nos deficere in solutionibus supradictis vel eorum aliqua, in parte vel in toto, loco et terminis supradictis, promittimus eisdem mercatoribus et utrique eorum insolidum per stipulationem solempnem refundere, reddere et restaurare, omnia dampna, expensas et interesse, quæ et quas dicti mercatores vel eornm alter, seu ipsorum vel alterius ipsorum procuratores, ratione dictæ pecuniæ sive partis ipsius non solutæ debitis loco et termino, dixerint seu dixerit suo verbo simplici se fecisse, sustinuisse vel incurrisse, in judicio vel extra judicium, super quibus ex nunc ut ex tunc nullam aliam fieri volumus taxationem aut probationem, vel sacramentum, exigi seu requiri ; set eorum vel alterius eorum, seu ipsorum vel alterius ipsorum procuratorum, simplici verbo credi.

Et, nichilominus, pœnæ nomine et pro pœna, promittimus et nos obligamus ad solvendas ducentas marcas in subsidium Terræ Sanctæ illis qui pecuniam Terræ Sanctæ de mandato Papæ colligent, quotiens nos defecerimus in solutionibus supradictis et terminis, ut superius est expressum.

Et, pro præmissis omnibus et singulis firmiter observandis et plenarie adimplendis, obligamus nos, monasterium nostrum et successores nostros, et omnia bona nostra mobilia et inmobilia, spiritualia et temporalia, præsentia et futura, ubicurnque fuerint inventa, dictis mercatoribus et utrique insolidum et ipsorum hæredibus et-assignatis ; quæ bona ab ipsis, eorum hæredibus et utroque ipsorum, nos recognoscimus usque ad plenam satisfactionem omnium præmissorum precario possidere.

Volumus etiam et voluntarie consentimus super præmissis omnibus et singulis, scilicet tam debito principali quam ponis, dampnis et interesse et expensis, a dictis mercatoribus et utroque eorum, ipsorum vel alterius ipsorum hærede vel hæredibus, nuntio vel procuratore, coram quocumque judice et in quocumque loco et foro libere conveniri et ad judicium trahi, ultra vel citra mare Anglicanum, prout eis placuerit, ad solam requisitionem dictorum mercatorum vel alterins eorum, seu nuntii vel procuratoris eorum, et ad satisfactionem omnium præmissorum per censuram ecclesiasticam, vel quamcumque aliam censuram aut cohercionem, compelli.

Renuntiantes expresse in præmissis omnibus et singulis exceptioni doli, mali, vis, metus et fraudis ; conditioni sine causa seu ex injusta causa ; conditioni indebiti ; exceptioni non habitæ, non receptæ seu non numeratæ, dictæ pecuniæ; actioni in factum appellationis ; remedio omni tempore feriato; juri revocandi domum; conventioni judicum et locorum; contradictioni litterarum Apostolicarum ; beneficio restitutionis in integrum ; constitutioni de duabus diebus editis in concilio generali; juri dicendi creditores probare debere pecuniam seu debitum in utilitate ecclesiæ esse conversam seu conversum; privilegio crucesignatis et crucesignandis indulto seu indulgendo, et Anglicis ne ultra mare Anglicanum trahantur in causis; omnibus litteris et gratiis a sede Apostolica et curia regia inpetratis et inpetrandis; et omni juri et beneficio et exceptionibus quibus- 
ferred, in consideration of losses and expenses occasioned by a delay in repayment. Edward the First, in the thirty-fourth year of his reign, granted to the Frescobaldi ten thousand pounds, " de dono nostro, in recompensationem dampnorum et jacturarum quæ iidem mercatores sustinuerunt ratione retardationis solutionis debitorum prædictorum." s Among many other instances, we may notice that of two thousand pounds granted to the Bardi for the same purpose, in the year $6 \mathrm{Edw}$. II. ; ${ }^{\mathrm{t}}$ four thousand pounds to the same in $10 \mathrm{Edw}$. II.; ${ }^{u}$ and other large sums in that and the following reigns. ${ }^{x}$ Instances will occasionally be met with in the annexed extracts of presents being made by the King, not to the merchants themselves, but to their wives. ${ }^{y}$ As a precaution against imputations of scandal, we may observe that, by this expedient, the King's gift was secured to the individual merchant whom he might desire to reward for services: it would otherwise have been claimed and shared by the partners in the firm of which he - was a member. As the loans required of the Italians grew to be of larger amount, and the difficulty of supplying them increased, the necessity of offering interest seems to have been experienced. Edward the Third, in the thirteenth year of his reign, was so much encumbered with debts, and in such distress for money, that he was obliged to grant interest for a sum of one hundred and forty thousand florins borrowed of a Lucchese mer-

cumque, qua nobis in aliquo possent valere et dictis mercatoribus nocere; et specialiter juri dicendi generalem renuntionem non valere.

Et, pro prædictis omnibus et singulis tenendis, observandis et adimplendis, obligamus nos ipsos, monasterium et conventum prædictos, abbates et successores nostros futuros, et omnia nostra et dictorum monasterii et conventus, ac futurorum abbatum et successorum nostrorum, bona mobilia et inmobilia, præsentia et futura, eisdem mercatoribus et utrique eorum insolidum, distringenda, detinenda et capienda, etiam sine strepitu judicii, per senescallos et marescallos magaifici principis domini Edwardi Regis Angliæ illustris quoscumque, cum in aliqua solutione dicti debiti cessaverimus, vel non servaverimus omnia et singula supradicta.

- In quorum omnium testimonium sigilla nostra, abbatis et conventus, præsentibus sunt appensa. Dat. in pleno capitulo nostro Glastoniæ, pridie kal. Jun. A.D. 1293."-Arundel MS. no. II. f. 87 .

s See anvexed Extracts, cxil. $\quad$ t Ibid. cxxxvi. 'u Ibid. cxLviI.

x Ibid. xxix, xuIr, Lx, Lxxxvir, cxxxir, cxxxvi, cxlvin, clx, clxx, clxxvi, clxxxyI.

y Ibid, clxxx, chxxxir, cxcrin. 
chant, and to engage not to cross the sea into England until the sum advanced was repaid. ${ }^{z}$ The clause in his letters of obligation relating to the payment of interest is as follows : "Ad quam quidem solutionem dictis die et loco faciendam, necnon ad refusionem et solutionem dampnorum, expensarum et interesse, si quæ, ratione retardatæ vel non plene factæ solutionis prædictæ, præfatum Nicholaum, hæredes vel executores suos, incurrere contigerit (super quibus juramento dicti Nicholai, hæredum vel executorum suorum, absque alia probatione, fidem volumus adhibere) obligamus omnia bona nostra et hæredum nostrorum districtioni cujuscumque judicis competentis."

Security. Moreover the expediency of obtaining security for the sums advanced, although generally not insisted on, was not always overlooked. The involved circumstances of Henry the Third, at the end of his reign, rendered it necessary that his treasurer and officers of his household should become securities for the loans he required. a Edward the First, at the close of his reign, was similarly situated. And in the reign of Edward the Third, whose burdens were yet heavier, security for payment became a frequent condition of the loan. This security consisted sometimes in an assignment on a branch of the royal revenue for the amount received. In the year 4 Edw. III. all the customs of the kingdom were assigned to the Bardi of Florence, to hold for one year; they having undertaken to provide one thousand marks every month for the expenses of the King's household. ${ }^{b}$ Sometimes a religious house was made a party in the bond; ${ }^{c}$ and, in some instances, the Italian merchants themselves became the King's securities to other companies of their countrymen for sums advanced by them. Frequently in the reign of Edward the Third the names of peers and high officers of state are subscribed to the King's letters of obligation; and in the fourteenth year of his reign, the Earl of Derby was actually detained in confinement in France, for debts in which he had been the King's security, until he was released by the company of the Leopardi, who advanced the sum required. ${ }^{d}$

z Rym. Fæd. ii. p. 1082.

a Annexed Extracts, xxxin, xxxiv, xxxv, xxxvir, xLIv.

b Cal. Rot. Pat. p. 113.

c Annexed Extracts, xxxiI.

d Rym. Fœd, vol. ii. p. 1143. 
The modes of repayment were various. In general the creditor received Modes of a bill upon the Exchequer, from which payment was made to him direct or repayment. by assignment elsewhere. Such instruments were recorded on the Liberate Rolls, and a collection of them is now offered in the annexed extracts. Sometimes the keeper of the wardrobe both negotiated the loan and afterwards settled it. ${ }^{e}$ An assignment on a branch of the revenue was often granted where the debts were of large amount. ${ }^{f}$ In the twenty-seventh year of Edward the First, the whole revenues of Ireland were assigned to the Frescobaldi of Florence in payment of a loan of eleven thousand pounds, sterling. 5 Sometimes a portion of the proceeds of a lay or clerical subsidy was made over to them. ${ }^{\mathrm{h}}$ The collectors were ordered to pay certain sums into the hands of the creditor, and allowance was made in their account at the Exchequer. In the year $8 \mathrm{Edw}$. I. almost the entire proceeds of a subsidy of a fifteenth were thus paid away to different companies of Italian merchants. $^{i}$ The issues of the customs came more often into their chests than into the royal treasury, ${ }^{k}$ especially during the latter part of the reign of Edward the First, and the commencement of Edward the Second, when the whole receipts of the customs were made over to them.

VII. An indirect but valuable remuneration, which they received for the General adservices they rendered the King, consisted in the commercial liberties they vacruing to $_{\text {vantas }}^{\text {vang }}$ thereby secured, ${ }^{1}$ and in the offices with which he entrusted them. In those the Italians.

e Frequent instances may be met with in the Wardrobe books of the period, and in the Issue Rolls in the Pell Office.

$f$ The following are references to assignments upon branches of revenue, not specified in the text : Annexed Extracts, LIX, LXxI, LXxviI, LxxIx-LXxxIr. Abbreviatio Rot. Orig. 4 Edw. II. 5 Edw. III. rot. 42 . $6 \mathrm{Edw}$. III, rot. 19, bis. $16 \mathrm{Edw}$. III. rot. $35.18 \mathrm{Edw}$. III. rot. 29, 32.

g Annexed Extracts, cvir.

h Annexed Extracts, clvi, clx, clxi, clxx. Rym. Fœd. vol. ii. p. 296. Abbr. Rot. Original. $10 \mathrm{Edw}$. II. rot. 13. $4 \mathrm{Edw}$. III. rot. 33. 14 Edw. III. rot. 70. Cal. Rot. Pat. 15 Edw. III. p. 1. m. 7. i Annexed Extracts, Lxxxirr.

k Annexed Extracts, passim. Abbr. Rot. Orig. 2 Edw. II. rot. 17. 7 Edw. II. rot. 7. 9 Edw. II. rot. 16. 1 Edw. III. rot. 25. Cal. Rot. Pat. 16 Edw. I. 3 Edw. III. p. l. m. 1. 14 Edw. III. p. 2. m. 20.

1 See an inspeximus by Edward III. of a charter of privileges granted them by Edward I. in the thirty-first year of his reign. Rym. Fod. vol. ii. p. 747 .

voL. XXVIIL. 
Mercantile privileges. times of prejudice and misgovernment, foreigners would hardly have been suffered to pursue such extensive traffic in the kingdom, had it not been that they engaged the King's good-will by the immediate advantages he received from them. By an ancient custom, they were obliged to dispose of their cargo within forty days after landing, and hosts were awarded them, whose business it was to watch and report upon their dealings. Almost the only notice which occurs of the former of these restraints arises from the representations and petitions which were made to the King by the native merchants respecting its infringement. ${ }^{m}$ However, in the seventeenth year of Edward the Third, it became a subject for legislation, as appears from the following extract from the Parliament Rolls : ${ }^{n}$

"Item fait a remembrer que les susditz prelatz et grantz a per eux, et les dites communes a per eux, feurent puis chargez de eux aviser sur les pointz souyescritz : cest assaver ;

"Primerement, des Lumbards et autres marchandz aliens qi demurent assiduelement en la terre pur marchander et ne fyrent unques nul eyde au Roi, et se coevrent par une chartre grantee par le Roi l'aiel as marchandz aliens repeirantz en Engleterre. Par la quele chartre ils ne deveroient mye estre eidez mes pur lour demure de xl jours pour lour descharger et recharger. Et, quant notre seigneur le Roi feust en Bretaigne, feust accordez qils deveroient estre taillez et taxez pur le temps q'ils out demeurez; et sils ne voloient paier la dite taillage qils voidassent la terre deinz les xl jours. Sur queu chose les ditz prelatz, grantz et communes, deivent aviser si celle chose soit a faire ou ne mye.

"As queux prelatz, grantz et communes, feust avis qe les marchandz aliens qi sont demeurantz et conversantz en roialme, et prenent les profitz en roialme si avant ou plus come font les marchandz denzeyns, deivent eider et porter charge entre autres du roialme, pur le temps qils ont demurez, come desus est dit.

"Par qoi acordez est et assentuz qils soient taxez et taillez pur le temps qils ont demurez, ou qils voident la terre en la manere susdite."

With regard to the regulation respecting surveillance by means of hosts, m Rot. Parl. vol. ii. p. 9. Notices of such complaints often occur in the Fodera; but I have mislaid the references.

n Rot. Parl. vol. ii. p. 137. 
I cannot find that it was enforced with any strictness during the reigns of the three Edwards. It seems to have extended no further than merely assigning peculiar houses for their residence, in London, in the street which thus received the name of Lombard Street. I have seen, among the records of the Queen's Remembrancer's Office, minute returns made into the Exchequer by the hosts thus appointed by the Mayor of London, in the reign of Henry VI.; but I have met with none for the period to which the present paper relates. Indeed, having abundant evidence of the unrestrained trade in money which they were allowed to exercise in all parts of the country, we cannot hesitate to conclude that it had become only a nominal restriction upon their mercantile freedom.

The offices which they held by the King's appointment, and which were Offices enprobably bestowed on them in reward for their services, were a more direct them. source of profit and advantage. They were frequently collectors of subsidies and customs $:^{n}$ the mint too was generally in some degree under their charge, ${ }^{\circ}$ and the coiners there were principally natives of Italy. ${ }^{p}$ But there are instances of their having held offices of much greater trust and honour. Amerigo de' Friscobaldi, as will afterwards appear, was constable of Bourdeaux in the first years of Edward the Second; Alberto de' Medici was justice of the Jews in Agenois, at the same period q ; and Antonio Pessagno, a Genoese merchant, also held the office of constable of Bourdeaux by an appointment dated in the eleventh year of the same King. ${ }^{r}$

Again, there are traces of their acting as the King's emissaries and agents Employed as in foreign parts; and sometimes at a period when the success of an the King's

u Annexed Extracts, Lxxxır. Rot. Lib. 9 Edw. I. m. 4.17 Edw. I. m. 2. 19 Edw. I. m. 5. $20 \mathrm{Edw}$. I. m. 4. Abbreviatio Rot. Orig. $2 \mathrm{Edw}$. I. rot. 15, bis. $2 \mathrm{Edw}$. II. rot. $2.5 \mathrm{Edw}$. II. rot. 4. Pell. Recept. 1 Edw. I. mm. 2, 3.

- Rym. Fod. vol. iii. pp. 727, 915. Rot. Jib. 8 Edw. I. m. 9. 28 Edw. I. m. 3. Abbr. Rot. Orig. $7 \mathrm{Edw}$. I. rot. 1. $9 \mathrm{Edw}$. I. rot. 3. 1 Edw. II. rot. 1. $18 \mathrm{Edw}$. III. rot. $28.23 \mathrm{Edw}$. III. rot. 46. Cal. Rot. Pat. 17 Edw. III. p. 3. m. 4.

p On the Liberate Roll, $32 \mathrm{Edw}$. I. m. 4, is an order for payments to be made to between two and three hundred foreigners, principally Italians, coming from Paris and other places to work in the mint at London.

q Rym. Fæd. vol. ii. p. $75 . \quad$ r Ibid. p. 347. 
approaching war might depend upon the alliances with which he might be able to strengthen himself there. ${ }^{\mathbf{r}}$

In the fifth, sixth, and seventh years of Edward the First, large sums were placed in the hands of the merchants of Lucca " ad quædam negotia nostra quæ eis injunximus expedienda." s Throughout the reign of Edward the Second, and during the earlier part of that of Edward the Third, Antonio Pessagno and Antonio Bache, Genoese merchants, were frequently engaged abroad in the King's affairs; and from the largeness of the sums placed at their disposal, it may be inferred that the business they were intrusted with was of considerable importance. ${ }^{t}$

In such negotiations the Italians might practise with effect the diplomacy for which their country was already famous. Indeed their general qualifications must often have proved serviceable in distant and important missions. The King could employ them on affairs which, from the tediousness of travelling, and the general want of acquaintance with remote places, his own subjects were unfit to execute. He found in them a race of men far excelling those of his own dominions in the requisites for political agents or men of business. An universal commerce enlarged their minds, and gave them a knowledge of men and things unusual in those times, which their ambition and love of gain would dispose them to improve and apply with effect; by means of their partners and countrymen they had easy communication with every part of Europe and with Asia; they were always ready themselves to advance the sums necessary to forward the business in hand; and the favour they enjoyed in all countries of Europe, and in the East, added another facility to the happy prosecution of the affairs they undertook. It is recorded in a work which treats of the grandeur of the Florentine nation, printed at Florence in 1780, that in the year 1294 there were not less than twelve Florentines at the court of Rome holding the title of ambassadors from the principal states of Europe. The writer relates, that, upon being presented to Pope Boniface VIII. they congratulated

r Annexed Extracts, clxxxyr, clxxxix, cxc, cxcri, cxciv.

s Ibid. LXxII-Lxxvir.

t I draw this information from the Liberate Rolls of this reign, but I have inadvertently omitted to extract the writs relating to the subject. 
him upon his elevation to the tiara in such elegant language, that his Holiness turned to his courtiers and exclaimed that, truly, the Florentines were the fifth element of the world. ${ }^{\text {u }}$

There was yet another way by which the Italians derived benefit from ${ }_{\text {intercessions }}^{\text {The Kings }}$ their connexion with the King. In the multitude of their operations abroad, in their beit sometimes happened that they needed the recommendation of a powerful balf with patron, or an intercessor with an offended prince, or a protector from in-Princes. justice. When applied to for assistance, in such cases, the King, who had received so many obligations at their hands, could not refuse to exert his interest in their behalf. Documents may be quoted from the "Foedera" which prove that occurrences of this kind were not unusual. Edward the Second, in the fourth year of his reign, addressed the Pope, urging him to distinguish with his favour two brothers of Amerigo de' Friscobaldi, and to countenance them in a cause then pending in his court. $x$ The same prince, in the fifth year of his reign, wrote to the King of France, and prayed him to liberate certain Genoese merchants, relations of Antonio Pessagno, who had been arrested by the French King's commands. y In the eleventh year of his reign, he directed a letter of general recommendation to the King of France, in favour of the Bardi of Florence, in which he mentioned with gratitude the services they had rendered him, and the burdens and charges they had undertaken for his accommodation: it was backed with similar letters to Louis of Valois, Louis Comte d'Evreux, and the Sire de Soly. ${ }^{z}$ In his thirteenth year he wrote repeatedly and warmly to the Pope, the Cardinals, and the King of Sicily, soliciting their interest in behalf of Antonio Pessagno of Genoa, who was striving to obtain payment of a debt of large amount, due for a loan advanced to the Master and Brethren of the Hospital of St. John of Jerusalem. ${ }^{\text {a }}$ In his fifteenth and sixteenth years, he endeavoured to obtain from the King of France restitution of damages for a Genoese, on account of a ship laden with merchandize to the value of $5,716 l$. sterling, which had been seized by a French admiral, in the time of the late

u Delle eccelenze e grandezze della nazione Fiorentina, Dissertazione storico-filosofica. A Firenze, 1780. p. 18.

× Rym. Fod. vol. ii. pp. 123, $124 . \quad$ y Ibid.p. 159.

z Ibid. p. 347.

a Ibid. pp. $403,420,424$. 
Extent of their trans. actions as the ti King's money-lenders in England, during the reign of Henry III.

Influence of the alliance between the King and the Emperor Frederic.
King of France. ${ }^{b}$ About the same time, he sent a certificate to the King of Sicily, that Vanne Fortigair [Fortiguerra] a merchant of Aymer de Valence, Earl of Pembroke, had passed an honest life in England for fifteen years ; and solicited, in his behalf, restitution of some wool which had been taken from him at Nice in Province, on suspicion of his being attached to the Ghibeline faction : and he wrote to the Pope and Cardinals desiring them to second his request. ${ }^{c}$

VIII. The Italian merchants appear to have had very little communication with Henry III. in the early part of that monarch's reign: they acted as bankers to the royal ambassadors at the court of Rome, but they seem to have been employed in England only as collectors of the Pope's revenue, or as money-lenders to private parties. Perhaps this may be accounted for by the close alliance which existed between the King and the Emperor Frederic; to whom he gave his sister Isabella in marriage, in his twentieth year. He certainly advocated Frederic's cause with zeal against the Lombard cities, who so strenuously resisted the Imperial yoke. The large sum of thirty thousand marks, sterling, which he gave as his sister's portion, must have powerfully contributed to support the Emperor against his insurgent vassals. It was not a nominal donation, as such engagements frequently proved. The full amount was paid ; and the order for the last instalment of ten thousand marks, dated 10 June, 21 Hen. III. is recorded on the Patent Roll of that year. ${ }^{\mathrm{d}}$ The bond for the debt is dated in May in the twentieth year, so that the entire sum was paid in the short space of thirteen months; an instance of expedition, in such affairs, very unusual at that period, and attributable to the sincerity of the King's desire to afford his brother-in-law effectual assistance. Moreover, the expressions in his letters to the Emperor, when he mentions the transactions of Italy, correspond with this indication of his warmth of partizanship. Several of these documents are entered in the Close Roll of 20 Hen. III. In one the King says, "Litteras imperialis excellentiæ vestræ, nobis per Advocatum de Aquisgrano transmissas, cum qua decuit reverentia, læte recepimus : set, intellecta per easdem attemptatione Lumbardorum inopinata contra majestatem celsitudinis vestræ ita

b Rym. Fœd. vol. ii. pp. 456, 503.

c Ibid. p. 470 .

d Ibid. vol. i. p. 232. 
irreverenter machinata, eam æquo animo ferre non valuimus; ad quam vindicandam si sufficeremus, libenter nos accingeremus; vestra gravamina non reputantes, sicut nec debemus, a nostris alienata;"e and at the same time he sent messengers to the Pope, with letters of urgent supplication in the Emperor's favour. We may suppose that such an alliance had the effect of retarding the progress of the Italians in this country-especially as their introduction here was through the Pope, the Emperor's antagonist-that it rendered them obnoxious to the King, and disinclined him from employing them as his agents and servants.

But the ambition of the Pope was destined to entangle Henry the Third in Transactions connexions with the Italians, which, it may be asserted with confidence, were ${ }_{\text {the kingdom }}^{\text {relative to }}$ a principal cause of the troubles which harassed him during the remainder of of Sicily. his reign. Upon the death of Frederic II. in the year 1250, the kingdom of Sicily, left vacant by that event, engaged the Pope's attention, and he used the utmost exertions to bring it under the temporal power of the Holy See. But it was never a part of the Pope's system to undertake alone, what duplicity and an impious application of the authority attributed to him might enable him to accomplish by the instrumentality of others. Accordingly, having experienced a stronger opposition to his designs than he had expected, foreseeing the difficulty and uncertainty of his enterprise, and the heavy expenditure it demanded, he looked around for a temporal prince whom he might draw into his plans, and who could supply the funds necessary to complete the undertaking. Richard, Earl of Cornwall, Henry's bro. ther, was the first to whom the Pope ventured to offer the bait of the crown of Sicily. But Richard was too cautious to be entrapped, and declined his proposals. Innocent, thereupon, judging well the character of Henry the Third, and hoping from his weakness and vanity to find him pliable to his will, offered him, for his son Edmund, the prize which prudence would have rejected. It was accepted ; and Edmund received a grant of the kingdom of Sicily by letters under the seal of Albert, the Pope's notary and legate, dated $38 \mathrm{Hen}$. III. ${ }^{\mathrm{f}}$ It soon appeared for what purpose the King of England had been thus honourably distinguished. The expenses which the 
Pope had already incurred were considerable; and the money had been raised by loans received from the merchants of Italy. Hardly had the ink dried on the instrument which invested Edmund with the kingdom, when a bull was directed to the Archbishop of Canterbury and the Bishop of Chichester commissioning them to raise loans to any amount, for the purpose of the enterprise, and to bind religious houses and the King's lands as security for the repayment.s While they were thus employed in England, the Bishop of Hereford (the chief agent in the business) was similarly occupied at Rome. He was provided with a bull authorising him to draw bills to any amount upon the prelates and religious houses of England; and to bind them to the interest as well as principal of the loans which he contracted in their name. ${ }^{b}$ The revenues of the church and state were thus at the Pope's command: for in the Italian merchants he found men able and willing to advance the largest sums upon such securities, and his influence with the King procured the payment of at least a considerable portion of the debts. Jealous of every farthing expended by his dupe for any other purpose than that in which he had engaged him, he writes to persuade him to abstain from superfluous expenses, and to content himself with the bare necessaries of life, in the following extraordinary epistle:

"Innocentius," etc. " Regi Angliæ," etc.

"Cum ad negotium, quod in persona carissimi in Christo filii nostri [Edmundi] Regis Siciliæ illustris, nati tui, assumpsisse dinosceris, prosequendum potenter et viriliter, prout decet tantum principem, multa sit pecunia oportuna, celsitudinem tuam rogamus et hortamur attentè, in remissionem tibi peccaminum districtius imponentes, quatinus ab omnibus expensis, tam piis (cum ipsius prosecutio negotii superet omnia opera pietatis) quàm aliis (exceptis duntaxat necessariis, quæ quoquo modo vitari non possunt) cohibeas de cætero penitus manus tuas. Sciturus pro certo quod, nisi ab hiis refrænaveris te omnino, credere non possumus quod habeas animum prædictum negotium prosequendi.

" Dat. Asisii, undecimo kal. Junii, pontificatus nostri undecimo." $i$

g Rym. Fœd. vol. i. p. 301.

h Matt. Par. sub anno 1255.

i Rym. Fœd. vol. i. p. 302. 
Not satisfied with this, he writes in a similar manner to the Queen, urging her to use all her influence with her husband, and to be importunate in entreating him to observe a strict economy. The concluding sentence is, "Quocirca celsitudinem tuam rogamus, monemus et hortamur attentè, quatinus et tu ab hiis [expensis] teipsam coherceas, et prædictum Regem ad id sæpe sæpius solicitis exhortationibus ex parte nostra, quotiens expedire videris, moveas et inducas." A third epistle in nearly the same words is sent to Peter of Savoy, the King's favourite. ${ }^{k}$

Innocent IV. died in 1254, but the negotiation was resumed in the same spirit by his successor. In the thirty-ninth year of Henry III. Alexander IV. in a bull directed to Edmund, in which he styles him King of Sicily, lays down the conditions upon which his enjoyment of that title is to depend. Of course, every advantage is secured to the Holy See, in case of the success of the enterprise. In the meantime Henry the Third is required to defray the costs already incurred (for which Italian merchants were creditors) amounting to 130,541 marks, sterling. With regard to future expenses, the Pope is to hold considerable land in Sicily in pledge for the repayment of what portion he may have contributed; and the King also is to add his security. 1 From this time the unfortunate monarch was harassed by incessant demands for sums infinitely beyond his means to supply: agents were sent from Rome to intercept his revenue; deputies came from Italian knights employed in the enterprise, requiring payment of the wages due to them; the clergy were subjected to ceaseless taxation; and the indignant Barons, who saw the kingdom drained of its wealth to support an undertaking which the whole world ridiculed, rose to depose a King who had accumulated such miseries on his people. Finally, to fill the cup of bitterness and mortification, the Pope deprived the son of the title and claims which had proved so ruinous to his father.

These transactions were the means of introducing the Italians in greater numbers into England; and, although we find no instances of loans of large amount contracted with them by the King, it appears from Matthew Paris that they were actively practising their money-lending dealings among the

k Rym. Fœd, vol, i. p. 302.

vol. XXvir.
1 Jbid. p. 318. 
nobility and with religious houses. He tells us that the houses which they had built for themselves in London were so costly, that although, at one period, anxious to leave the kingdom to escape the persecutions they suffered, they were constrained to remain by the loss they feared to incur by deserting them. $m$

Extent of their transactions as the King's money-lenders in England, during the reign of Edward I.

Early connexion of that prince with the
IX. With the reign of Edward I. we open upon an era of greater interest and importance in the operations of the Italians. Hitherto they appear principally as trading merchants or agents of the Pope. They had probably suffered too much from the failure of the projects upon Sicily, to allow themselves to be involved again in money transactions with Henry the Third. The personal character of that prince, the weakness of his government, the dissensions in his kingdom, and the heaviness of his present debts, must have frightened them from ventures, the success of which would have depended upon his prosperity. But the character of Edward the First, so remarkable for a combination of prudence and spirit, was formed to engage confidence. His connexion with the Italians began before his succession to the throne. Merchants of Lucca were employed by him to remit from Eng-

$m$ The interest of the following extract will, I hope, excuse its insertion. It occurs under the year 1251 ;

"Temporibus sub eisdem, usurarii Transalpini, quos Caursinos appellamus, adeo multiplicati sunt et ditati quod, nobilissima palatia Londini sibi comparantes, stabilem sibi more civium indigenarum mansionem statuerunt. Nec sunt ausi prælati obmutire, quia se mercatores domini Papæ extitisse affirmarunt: nec audebant cives obloqui, quia magnatum quorumdam, quorum, ut dicebatur, pecuniam ad multiplicandum seminabant, exemplo Romanæ curiæ, favore defendebantur. Veruntamen tunc temporis graviter in civili foro, domino Rege sic volente et caute procurante, sunt accusati et in causam ante judicem tracti ; et, sedente Londini judice ex parte Regis accusantis, velut schismatici vel hæretici et regiæ læsæ rei majestatis vocati, tenebantur, tanquam incarcerandi et gravius puniendi ; pro eo nimirum quod, se Christianos profitentes, totum regnum Angliæ turpissimo quastu foenoris macularunt; unde dominus Rex Christianissimus, qui juravit sancta instituta ecclesiæ conserrare illæsa, se conqueritur in conscientia sua graviter sauciatum. Quod cum non posset inficiari, capti sunt eorum aliqui carcerali custodiæ mancipandi ; alii vero in locis abditis latuerunt. Quibus auditis,gavisi sunt Judæi suæ habere jam participes servitutis. Tandem, interveniente haud minimæ pecuniæ quantitate, æmuli Judæorum Caursini in pace ad tempus sunt demissi. Dixeratque unus eorum mihi hæc de ipsis scripturo, sub attestatione magni sacramenti, quod, nisi mansiones sumptuosas comparassent Londini, vix aliquis eorum in Anglia remansisset." Matt. Par. p. 822. 
land the sums necessary to support his expenses in the Holy Land. ${ }^{n}$ On Italian merthat distant shore he found himself surrounded by them; and he sought his subsefrom their traffic and frequent intercourse with Europe and England, the quent partiameans of corresponding with foreign princes upon the enterprise he was them. engaged in, and of obtaining from his own country early intelligence of circumstances which might nearly concern him, in times so troubled and eventful. In his subsequent journey homewards, wherever he passed, he found them firmly established, and contributing largely to the prosperity of the kingdoms where they exercised their commerce. In the plains of Italy, fertilized by a superior system of cultivation; in the cities which overspread them, already adorned with master-pieces of architecture, overflowing with wealth, and peopled with a race of men excelling all others in the arts and sciences no less than in commercial enterprise-he beheld with admiration the proofs and effects of a civilization elsewhere unknown. The contrast of this scene with his own rude island was not lost upon him. Throughout his reign he extended to them his protection and favour, encouraged them to

n An account of payments in the wardrobe in the year $1 \mathrm{Edw}$. I. preserved in the Queen's Remembrancer's Office, contains the following entries :

"Item, liberavit domino Edwardo pcclxxxijli. xis ad perficiendas м м marcas, quæ missæ fuerunt domino in Accon' per manum Peregrini de la Pounte et Willielmi de Blyburgh, pro societate Lucæ de Luka."

"Item, in expensis Pelerini de la Penne et Willielmi de Blyburgh adeuntium dominum in Terra Sancta cum prædictis м м marcis, missis per societatem Lucæ de Luka, in passagio maris, anno Ivto. xxijli. vis, viiiid."

"Item, liberavit Baud Aldebrand' mercatori Senensi xl marcas, pro cariagio м м marcarum de Londonia usque Parisias, pro paga ibidem facienda pro domino de denariis integris."

See also in the Chancellor's Roll 1 Edw. I. an account of the receivers of the twentieth granted to Henry III. at the end of his reign. Under the head of money sent to Prince Edward after he had left England are the following entries :

"Regi antequam esset Rex, per manus Lucæ de Luka et sociorum suorum, mercatorum de Luka, anno prædicti Regis Henrici lvo. v mille marcas; sicut continetur in quodam compoto cui appensum est sigillum Roberti Burnel.

" Et eidem, per manum Jacobi de Luka et sociorum suorum, mercatorum de Luka, anno pradicto, M м marcas ; sicut continetur ibidem.

" Et eidem, per manum prædicti Lucæ et sociorum suorum, mercatorum de Luka, et Peregrini de la Poynte, anno præedicto Regis H. lvjo. occexxxix marcas, ix solidos ; sicut continetur ibidem." 
trade with his people; by his bounty drew them over in large numbers; and enabled the wealthiest companies of Florence and Lucca to spread their agents over the whole kingdom. Such policy was its own reward. A better market was found for the produce of England; the activity of the native merchants was stimulated; and increased capital was circulated through the kingdom. In his greatest exigencies he was relieved by powerful and willing supporters; and he had at hand intelligent agents to prosecute his Large expen- political negotiations abroad and at home. The activity of his reign, and ditures during this the vast expenditure which incessant wars made necessary, gave them continual employment. The first of the annexed extracts in this reign is a mandate to the Treasurer to pay certain merchants of Lucca a sum which the King had borrowed of them in Palestine ${ }^{\circ}$ : and we have evidence that the merchants of Lucca and Sienna, but particularly his favourite agent, and probably counsellor, Lucas de Lucca, were frequently employcd in his service while he remained there. The war in Wales which began early in his reign, and revived after a short cessation ; his journey into France, in his fourteenth year; the wars in Gascony and Flanders, which were unsuccessfully carried on, at an enormous expense, chiefly by means of mercenary forces and dearly purchased alliances with continental powers ; finally, the repeated expeditions against Scotland, continued through a third part of his reign, compelled him to exert all his art and authority to recruit his exhausted exchequer. He imposed additional duties upon commerce; he took frequent subsidies from his lay subjects; the clergy were taxed for his benefit; he forfeited the property of the Jews, whom he drove from his kingdom; and he spoiled the churches of their plate and treasure. Still his revenue was insufficient to support his projects. The sudden demands, caused by the boldness of his political schemes, perpetually obliged him to anticipate his income. When at a loss for money, he could find none among his own subjects sufficiently wealthy to afford him the immediate assistance he required. But he obtained with apparent facility, from the Italian bankers, who now flocked around him, the ready supply which their inexhaustible resources could always yield.

- Annexed Extracts, xuriIr. 
In the eighth year of his reign, we find a writ of allowance to Reyner Notices of Magiar', merchant of Lucca, and Giles de Audenarde, receivers of the sub- loans considy of a fifteenth, for divers sums, amounting to fifteen thousand marks, delivered by them to thirteen companies of merchants of Florence, Lucca, Pistoia, and Sienna. ${ }^{p}$

In the ninth year, the keepers of the Exchange in London delivered ten thousand pounds to Lombard merchants (as they are styled in the record) in part payment of sums which they had lent the King.q

In the seventeenth year, there is an order for payment of five thousand marks to Ricardo Guidiccioni and his partners, merchants of Lucca, for an equal sum procured by them for the King on loan, from the following companies : the Mozzi of Florence, the company of Jacopo Brabazon of Sienna, the Bardi of Florence, the Ammanati of Pistoia, the Circuli Neri, the Circuli Bianchi of Florence, the company of the sons of Beccori of Lucca, the Frescobaldi of Florence, a second company of the Frescobaldi, and the Pulci of Florence. ${ }^{r}$

In the eighteenth year, the Ammanati of Pistoia received from the Exchequer three thousand marks, which, by the King's command, they had lent to Otho de Grandison in aid of his journey to Jerusalem. ${ }^{\mathrm{s}}$

In the nineteenth year, there is an order to deliver ten thousand pounds to the Ricardi of Lucca, in part payment only of the King's debts to them. ${ }^{t}$

In the twenty-sixth year, in a more systematic manner, a sum of ten thousand pounds sterling was raised on loan among eleven companies of Tuscan merchants : and the total amount of the King's debts to the same companies, it appears, was twenty-eight thousand pounds; a sum nearly equal to his full ordinary revenue for the year. ${ }^{u}$

In the twenty-seventh year, the treasurer of the Dublin Exchequer is commanded to pay eleven thousand pounds to the Frescobaldi of Florence,

p Annexed Extracts, Lxxxir.

q See an account in the Queen's Remembrancer's Office, intitled "Compotus custodum cambii Londoniæ a die dominica proxima ante festum beati Dunstani, anno regni Regis Edwardi [primi] octavo, usque," etc.

$r$ Annexed Extracts, Lxxxix. $\quad s$ Ibid. xcir. $\quad t$ Ibid. xcrir.

u Ibid. xcvi-crir. 
lent by them for the expenses of the King's household, and for which he had made over to them all the issues of Ireland, and the money then in the treasury there. ${ }^{x}$

By an account of the company of the Frescobaldi of Florence, sent into the Exchequer in the twenty-seventh year, it appears that the King was then indebted to them fifteen thousand eight hundred pounds, which he had at different times borrowed of them, since the commencement of the twentythird year. ${ }^{y}$

And in the thirty-fourth year, in a writ of allowance for collectors of customs at Newcastle-upon-Tyne, we learn that ten thousand pounds were granted to the Frescobaldi, of the King's gift, to compensate their losses occasioned by delay in payment of large sums borrowed from them. ${ }^{2}$

To liquidate his debts, the King had assigned them the old custom of wools, wool-fells and hides, within England and Ireland; to be received from the first of April in the thirty-second year of his reign, until the full payment of the same. From the writ immediately following, it appears that they had also received a grant of the new custom, issuing from wools, wool-fells, hides, and other merchandise belonging to foreign merchants, to hold from the twelfth of July in the thirty-second year until the complete payment of their demands. And from the collectors of customs in London they received ten thousand six hundred and eighty-three pounds, between the first of April, in the thirty-second year, and the twenty-fourth of June, in the thirty-fourth year.

Finally, we learn from an account of the Frescobaldi Bianchi of Florence that they had received of the King's money the following sums: from the collectors of customs at Hull, 17,482l. 13s. 2d.; at Boston, 21,469l.

$x$ Annexed Extracts, cviri.

y See an account preserved among the records in the Queen's Remembrancer's Records, headed thus: "Ces sont les deniers qui notre seigneur le Roy doit a Coppe Joseph et Talde Janiani et a leur compaignons, marchauntz de la compaignie de Friscobaudz de Florence; les queux ils ount liverez a ses tresorers et ailleurs, por ses busoignes, puis le xxv. jour de Novembre, lan xxiii. [Ed. I.] come est contenu par parceles desouz escrites."

The account extends to the sixth of June, in the year $27 \mathrm{Edw}$. I.

z Annexed Extracts, cxir. 
17s. $4 d$. ; at London, 27,590l. 16s. $4 \frac{1}{2} d$. ; at Newcastle, 3,491l. 15s. $2 \frac{1}{2} d$. ; at

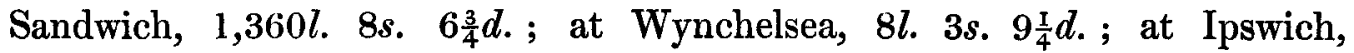

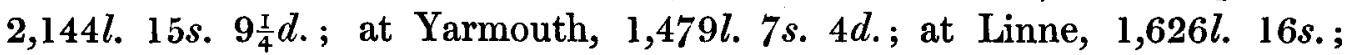
at Southampton, 6,408l. 7s. $1 d$. ; at Exeter, 126l. 7s. 8d.; from the Irish Fxchequer, 4,996l. 2s.; from the Justitiary of Ireland, in pollards, 463l. 6s. $4 d$.; from the profits of the custom on wool [in Ireland], whilst in their keeping, 1,280l.; from the mines of Devonshire, 2,510l.4s.; from the sheriff of Cornwall . . . . . ; from the collectors of the tenth levied on the clergy . . . . . ; amounting to nearly $100,000 l$. They had received these sums between the commencement of the year 23 Edward I. and the end of the year 2 Edward II. The account was sent into the Exchequer in consequence, apparently, of an inquiry instituted at the last mentioned period respecting the monies received by the Italian merchants from their assignments on the royal revenue, and there can be little doubt that these sums were received in payment of debts which Edward the First had contracted with them. ${ }^{\text {a }}$

Moreover, during this reign, the Italians were hardly less active in Ireland The Italian than in England. As early as the third year, merchants of Lucca were in ireland. acting as farmers of the new custom of wool and wool-fells, and they continued in the office to the end of the eighth year. From the tenth to the twelfth year the customs were farmed by merchants of Florence for $1,000 l$. per annum, and they were afterwards again entrusted to merchants of Lucca. $^{b}$ It appears from a document remaining among the Queen's Remembrancer's records, that it was represented by commissioners, who about this time had been despatched into Ireland to inquire into certain abuses of the government, that the King had suffered loss from the cheapness at which

a See an account among the records of the Queen's Remembrancer's Office, thus intitled :

" Compotus Bettini Berte, Almarici Berte, Petri Paunche, et Lapini Altaniane, mercatorum de societate Friscobaldorum Alborum de Florentia, pro se et sociis suis, mercatoribus societatis prædictæ, de diversis pecuniarum summis, de denariis tam Regis Edwardi fili Regis Henrici quam Regis Edwardi filii prædicti Regis Edwardi, in Anglia et Hibernia receptis, a festo S. Michaelis, anno regni prædicti Regis Edwardi filii Regis Henrici xxii. finiente, usque--" (sic)

The account extends to the fourteenth of April, $2 \mathrm{Edw}$. II.

b Views of accounts in the Queen's Remembrancer's Office. 
the new custom had been let to farm to the Florentines; for that in the eighth year, according to the account rendered by the Lucchese, $1,700 l$. had been received. They affirm that the new custom might be let out to farm for 2,000l.; and they add, "such depreciation of the revenue is not to be borne." Moreover, they make mention of a public report, that the Justitiary of Ireland participated with the merchants of Florence in their profits from the custom, and that he was a partner in their company, having a share in their ventures. We may easily conceive that enterprising merchants would find abundant opportunities of enriching themselves in a country where the government was lax, and the native traders unable to compete with them.

In the nineteenth and twentieth years, the new custom of wools in Ireland was still in the hands of the Lucchese merchants. And in the twentyseventh year the whole revenues of the country were made over to the Frescobaldi, as was before mentioned.

But, while they were thus engaged, they were frequently called upon, like their fellow-countrymen in England, to supply the King's necessities from their funds. In the rolls of the Dublin Exchequer, transmitted to the Exchequer at Westminster, I have seen frequent notices of sums delivered to Italian merchants in repayment of loans received from them, but am unable to give particular references.

Transactions of theItalians as the King's moneylenders in England, during the reign of Edward II.

The King's conduct upon his accession, with regard to Scotland, justified by his financial embarrassments.
$X$. The first actions of Edward the Second, upon his accession to the throne, have always been stigmatised by historians as impolitic in themselves, and indicative of a want of spirit in that prince. The apparent pusillanimity with which be withdrew from a struggle so long and intrepidly maintained by his father, and in direct opposition to his dying injunctions, has subjected him to the contempt of all ages. But circumstances connected with the present subject suggest arguments which may explain or palliate the seeming weakness of his conduct. The defects in the constitution of the armies of early times have often been pointed out. It is well known how weak were the ties by which they were kept together. Composed principally of the retinues of the nobility who were engaged to serve only for a limited term, by the tenure of their lands or by indentures of service, they were unsuited to a protracted campaign. Edward the First 
seems to have made efforts to remedy this evil by maintaining corps of mercenaries-Irish, Welsh, and native troops. But, in the condition of affairs at the moment of Edward's death, this precaution proved a source of disaster. A principle of honour and the prospect of meeting an enemy might have withbeld the Barons from deserting their new Sovereign; but such influences were, of necessity, less powerful with the remainder of his followers. A war so long protracted, and prosecuted with such energy, was at that period almost unexampled. It appeared endless. Resistance became more and more strenuous; the invaded country had been repeatedly ravaged; and the brightest success would bring them little or no recompence. Long arrears were due to the army; the emptiness of the Exchequer was no secret; and the effect of the death of the King, whom they feared. and loved, must have been to dishearten them and render them desperate of obtaining their dues. By what promises could the young King keep such troops united? or, if in this he had succeeded, what ultimate results could he have looked forward to? But the enormous weight of his father's debts pressed upon him : temporary success was insufficient; a battle won would not remove his difficulties, or satisfy the demands of his soldiers: and, although the resolution he formed in this dilemma wears to our eyes the character of weakness and timidity, it was apparently unavoidable. It certainly was followed by conduct which proved him possessed of much firmness and rectitude of principle, and to be not incapable of self-devotion. He discontinued a contest which he could only maintain, for a time, by the ruin of his followers, and retired to his capital, not, as has been charged against him, to yield himself to effeminate pleasures, but to submit to tedious restraints and self-denials in persevering efforts to satisfy the claims of his father's creditors. The Liberate Rolls of the first years of his reign abound His exertions with orders upon the Exchequer in their favour. Independent of other to pay his fapayments, no less a sum than one hundred and eighteen thousand pounds, sterling, was delivered to the keeper of the late King's wardrobe, to pay off the debts incurred in his office. ${ }^{c}$ At the same time, twenty-eight thousand

c Rot. Lib. 2 Edw. II. mm. 4, 2. 3 Edw. II. m. 2. 4 Edw. II. m. 3.

VOL. XXVIII.

$2 \mathrm{~K}$ 
pounds were applied to the discharge of debts contracted by himself, when Prince of Wales. ${ }^{d}$ The law officers and other higher servants of the Crown now received arrears of salary which had long been accumulating. There is on record a writ, dated in the second year, ordering payment of eight thousand five hundred pounds sterling, due to Gascons who had served Edward the First in the war in their own country. ${ }^{e}$ Deputies had, for some time, been in England pressing their demands; their daily expenses had been allowed them; and the circumstance affords an instance of the necessity there was at once to reduce the exorbitant rate of expenditure already too long continued. The exertions of the King were so warmly and steadily maintained, that the bulk of the debts was discharged within the first six years of his reign, although orders on the Exchequer for such payments are met with as late as the thirteenth year. The consideration of these circumstances may

The effect upon his popularity.

throw a new light upon the history of this period. It is not for me to trace their results ; but the inquiry suggests itself, whether the early unpopularity of Edward the Second may not be attributed to another cause, not less powerful than that of his courtiers' jealousy of an undeserving favourite, to which it is commonly ascribed. The necessary retrenchments in the expenses of the household, and the economy enforced in all departments of government, must have been distasteful to the officers of the Crown, whose interests were injured; the effect of a considerable diminution in the King's expenditure must have extended generally through the people; an unusual strictness must have been exercised in collecting the royal revenue; and can we wonder that anger and discontent were engendered in all classes ? The prevalent ignorance of political affairs rendered them blind to the true causes of their suffering: and Edward the Second incurred the obloquy which should have fallen on his father.

The Italians, It appears from a record remaining in the Queen's Remembrancer's Office and espe- that, of the one hundred and eighteen thousand pounds which were applied cially the Frescobaldi, persecuted by the revolted Barons. to the payment of Edward the First's debts, a considerable portion was red Rot. Lib. 1 Edw. II. m. e Rot, Lib. 2 Edw. II. m. 3.

2 Edw. II, mm. 6, 4, 3, 2, 3 Edw. II. m. 2. 
ceived by the Italians. ${ }^{f}$ The Frescobaldi alone obtained fifty-six thousand five hundred pounds within the three years immediately subsequent upon that King's death; the Bellardi eighteen hundred pounds, and the Bardi four thousand six hundred: and it is worthy of remark that they thereby incurred the odium and jealousy of the disaffected to Edward's government. The fourth article of the Statutes of the Barons, in the fifth year of Edward the Second, is directed against them. It orders that the customs of the kingdom shall not henceforward be entrusted to the keeping of aliens; and that all the profits therefrom, and the other revenues of the country, shall be paid into the Exchequer, and not into other hands. The fifth article orders that all merchants alien, who have received the profits of the customs or other of the King's monies, be arrested, together with their goods, and obliged to render account of their receipts. But the twenty-first article discovers their feelings more plainly. Amerigo de' Frescobald and his company are there singled out, and made the peculiar objects of persecution. It is ordered that their persons and goods be arrested, and that, in default of their appearing to render sufficient account of the monies they have received, they be banished from the kingdom and held as outlaws.g Already warrants had been dispatched to officers abroad for the apprehension of Amerigo de' Friscobaldi, who was then constable of Bourdeaux, and others of his company. They had been recalled by Edward the Second, by a writ to the seneschal of Gascony, dated the 27th of July, in the fifth year. They were now renewed, and Giovanni Guicardi and Alberto Medici, temporary keepers of the office of constable of Bourdeaux, and receivers of the revenues of the Duchy of Aquitaine, were appointed to make the arrest. They received their commission on the eleventh of November; and their return upon its execution is dated on the fourth of December following. Their letter is of historical interest ; and its tone, when speaking of the offenders, discovers the power and consequence which the Frescobaldi had attained to in the

f The record is entitled "Onus Scaccarii," and it contains an account of payments made by virtue of orders upon the Exchequer, assigned to the keeper of the wardrobe for the purpose of paying off the late King's debts.

g Rot. Parl. vol. i. sub anno. 


\section{time of their prosperity. ${ }^{\mathrm{b}}$ Messengers were afterwards sent to the court of Rome to procure the arrest of those of the company who had fled thither to}

h This letter is among the accounts and miscellaneous records preserved in the Queen's Remembrancer's Office ; which after centuries of neglect, and exposure to many risks and losses, have been narrowly saved from a decay which had already fastened on them, by the exertions of the late Record Commission, and of the present keeper of the Public Records, his Lordship the Master of the Rolls. The following partial copy is all that 1 am able to offer.

"Venerabili patri in Christo, domino suo karissimo, domino J. Dei gratia Norwycensi episcopo, sui humiles et devoti Johannes Guicardi et Albertus Medici, clerici, custodes constabulariæ Burdegalæ et receptores exituum dicti ducatus, debitam reverentiam cum honore.

“ Noverit vestra dominatio nos novem paria litterarum domini nostri Regis Angliæ, ducis Aquitaniæ, patentium, per manus Johannis Scuroli servientis regii, die Lunæ ante festum beati Martini in noctis crepusculo, recepisse, in summa, captionem Emerici de Friscobaldis nuper constabularii Burdegalæ, et Hugonis Hugolini tenentis locum suum, et aliorum mercatorum de societate eorum, et revocationem officiorum sibi per dominum Regem in terra ducatus commissorum, quæ nobis de novo commissa sunt, continentia. Quarum auctoritate noveritis nos sic in dicto negotio una cum locum tenente senescalli Vasconiæ processisse quod prædictus Hugo Hugolini, Guelfe de Friscobaldis frater naturalis prædicti Emerici, et duo alii, unus nomine Gracius de Castro Florentino et alius nomine Jaquettus Symoni, receptores nuper exituum prædicti ducatus pro prædicto Emerico, licet essent sparsi per diversas partes dicti ducatus, sunt capti in castro Burdegalensi ; et ibi tamdiu juxta mandatum regium detinebuntur donec de jpsis per dominum nostrum Regem aliud fuerit præceptum vel ordinatum. In quorum manibus seu potestate modica bona fuerunt inventa, de quibus inventaria fideliter sunt confecta. Tamen expensas aliquas et non multum magnas fecimus circa captionem prædictarum personarum ; ad quas capiendas nos oportuit per diversas partes laborare, et ducere nobiscum majorem Burdegalæ cum armis versus partes Agennenses, videlicet apud Marmandam, ubi prædictus Hugolinus erat, pro saniori consilio habendo et auxilio fortiori. Quia prædictus Hugo rebellis suo modo mandato Regis videbatur, asserens se habere litteras regias per quas litteræ nobis missæ anullarentur; et, ad ultimum, ostendit unam litteram regiam clausam sub magno sigillo, directam senescallo Vasconiæ vel ejus locum tenenti, per quam mandabatur ipsi senescallo quod, cum ipse dominus Rex nuper mandavisset atachiari Emericum de Friscobaldis et socios suos pro compoto suo reddendo, et ipse Emericus se aplegiasset ydonee de compoto suo reddendo, mandaret ipsum Emericum et socios suos, si arrestati fuissent, ab arresto hujusmodi liberari. Ad quod fuit ei responsum quod illa littera nihil operabatur pro eo in hac parte, set opportebat eum remanere juxta mandatum ultimo missum et opportatum per Johannem Scuroli. De qra littera mittimus vobis copiam presentibus interclusam. Verum, cum sumus simplices et modici sensus ad tantum officium, nobis commissum per dominum Regem, regendum, (quamquam usque nunc pro posse fecerimus et facere intendamus et affectemus omnia quæ cedere possint ad dicti domini Regis comodum et honorem, et bonam voluntatem habeamus serviendi fideliter ipsi domino Regi et suis in omnibus quibus sufficere possimus,) supplicamus dominationi vestræ, pro Deo et pietatis intuitu, quod 


\section{escape the persecution; and the Pope's permission was solicited to convey them, after apprehension, into England.}

laboretis erga dominum Regem et alios de consilio regio quod cito ordinetur de constabularia Burdegalæ et thesauraria Agenni, necnon et de senescalciis Vasconiæ, Agenni, Petragorici et Xanctoniæ, qui sint potentes et nobiles personæ de partibus illis, prout ad ipsa officia noveritis pertinere, et quod cito transmittantur. Quia sciatis [quod] periculum est in mora. Nam sciatis quod terra Vasconiæ et, specialiter, terra Agennensis sunt in malo statu, tum propter guerras baronum quas habent inter se tum propter latrones murtrarios et itinerum captores, qui in ipsa terra Agennensi, specialiter, per ipsos barones foventur et etiam sustinentur; propter quorum maleficia infinita via mercatoribus et aliis bonis hominibus est præclusa, et sic impedita quod nullus mercator, nisi congregata sibi bona comitiva, nec etiam burgensis aliquis villarum Agennensium vel aliunde, audet hiis diebus villas suas exire nec terras suas in propriis personis visitare, aut transire per terram Agennensem prædictam. Nec barones prædicti a guerris antedictis pro aliquibus inibitionibus seu mandatis eis factis per locum tenentem senescalli Vasconiæ et senescalli Agenni, seu per alios ipsorum nomine, factis, cessare volunt. Ymmo, mala malis accumulantes, quando sentiunt quod contra eos debet procedi ad ipsorum corpora et bona capienda, propter inobedientias et excessus per ipsos datos, incontinenti se supponunt protectioni domini Regis Franciæ, et appellant."

[I have here omitted twenty lines of the original, which relate to general matters coneerning the government of the Duchy.]

“Mittimus etiam vobis duo paria litterarum Emerici de Friscobaldis, missarum per ipsum prædictis Hugolino, Guelfo et Gracio ; quæ fuerunt captæ una cum latore earum ad hostium castri Burdegalensis, eodem die quo prædictus Guelfus fuit captus, videlicet, die Martis ante dictum festum beati Martini. Quæ continent in summa, videlicet, quod Emericus de Friscobaldis mandabat Guelfo fratri suo in Vasconia quod mora eorum in Anglia non erat pro eis utilis tempore isto; et, propter hoc, noluit transire ista vice in Angliam dictus Emericus de Friscobaldis ; et quod invenerat fratrem suum Betinum, qui venerat de Anglia, apud Bruges : unde mandabat dicto Guelfo quod ipse, cum tota pecunia, vinis et aliis denariatis, quæ habere posset et congregare, veniret ad eum, vel mitteret sibi cum tota qua posset celeritate; et quod præmissa non prætermitteret pro toto mundo. Et, si pecuniam non haberet, quod emeret vina et alia, non habendo respectum ad pretium, etiam si dupplum pretii deberet dare pro tonello vini, dum tamen illa posset habere; et quod solutiones hujusmodi præmanibus assignaret, si aliter expectare non posset creditoribus, super custumam vel super ballivas, prout sibi videretur faciendum. Insuper significabat ei quod comes Cornubiæ, volens hobedire ordinationi baronum Angliæ, veniebat citra mare; quare dubitabat quod ipsi Guelfo et sociis suis, et aliis qui erant in ducatu, fieret ad procurationem dictorum baronum aliqua novitas, et dubitabat multum quod arrestarentur; et quod ipse ipsis juvare non posset nunc sicut prius, quando comes et ipse Emericus tenebant statum suum et erant in dominio suo. Quapropter mandabat ei quod, si timeret arrestari tali modo quod ad voluntatem suam se deliberare non posset, non expectaret arrestum pradictum, set se properaret erga ipsum in quantum posset: tamen, si expectare posset sine periculo quousque misisset sibi mille tonellos vini, vel magis aut minus, quod, pro Deo et pro om- 


\section{These events seem to have acted as a temporary check upon the zeal of the Italian money-lenders, in their dealings with Edward the Second. For,}

nibus sanctis suis, hoc faceret et sine mora ; et quod per litteram Regis seu aiterius hominis viventis non solveret denarios alicui homini de mundo, nisi per litteras Betini vel per litteras dicti Emerici.

"Domine, certi sumus quod vos factum hujusmodi, quod magnum et honorabile est, licet inutile propter tædia expensas et labores magnos qui ex illo dependent, procurastis nobis; de quo vobis quantum possumus regratiamur. Miramur, tamen, quia in commissionibus nobis factis non fit mentio quod nos capiamus vadia quæ ad officium constabulariæ et thesaurariæ Agenni, et aliorum officiorum nobis commissorum, pertinent, sicut alii constabularii et thesaurarii, et alii tenentes officia nobis commissa, percipere et habere consueverunt. Circa quæ officia oportet unum nostrum semper, usque ad adventum constabularii, morari in castro Burdegalensi, et alium in terra Agennensi, et facere magnas et diversas expensas, et tenere plures personas quam consuevimus facere, ratione officiorum prædictorum : et non credimus fore intentionis regiæ neque vestræ quod ad propria custagia ducamus officia supradicta; quod sustinere modo aliquo non possemus. Quare, si placet, mittatis nobis per latorem præsentium garentum patens, per quod vestes, vadia et expensas, ad ipsa officia pertinentia, quamdiu habuerimus eorum administrationem, habere valeamus ; prout alii constabularii et thesaurarii Agenni et alii tenentes officia nobis conmissa ea habere actenus consueverunt; necnon et expensas quas fecimus et vadia pro hominibus armatis quos habuimus ad capiendum prædictum Hugonem et socios suos, quæ in compotis nostris allocentur; necnon et solutiones jam factas et imposterum faciendas de mandato senescalli Vasconiæ et ejus locum tenentis : cum plures et diversas solutiones fieri fecimus, ultra feoda et expensas ministrorum, pro negotiis domini nostri Regis per diversas partes prosequendis. Item, necesse est quod garentum domini Regis, missum pro mille tonellis vini in partibus istis emendis et sibi in Angliam mittendis, corrigatur ; quia non videtur sufficiens consilio harum partium pro garento nostro, propter verbum contentum in ipso garento in allocatione, quod est "cum illud sciverimus," etc. per quod non videtur quod ipsa vina vadant perj. culo Regis : licet, forte, sit regiæ intentionis quod suo et non alterius periculo transmittantur. Unde mutetur forma brevis, et mittatur certa persona de qua Rex confidat, cui per dictum breve ipsa vina nomine Regis tradantur, et custum positum circa emptionem et carriationem ipsorum vinorum usque Londoniam, necnon et expensæ seu vadia illius qui mittetur pro emptione et receptione dictorum vinorum, quæ per illum testificabuntur sub sigillo suo, mandetur per idem breve in nostris compotis allocari : et interim fiet provisio vinorum apud Burdegalam, prout nobis solvendum se obtulerit facultas. Super præmissis omnibus et singulis, et aliis quæ vestræ placuerit paternitati, dignetur ipsa paternitas nobis suis suam precipere voluntatem; cui in omnibus et per omnia parati sumus pro viribus hobedire. Et, si placet, ostendatis litteram præsentem domino Guillielmo Ynggne, cui scribimus super præmissis, set non ita plene. Dat. Burdegalæ, iij to die Decembris."

"Præterea sciatis, domine, quod mirabiliter fuerunt admirati locum tenens senescalli Vasconiæ et omnes alii de consilio Regis, et quasi totus populus, quia commissio tanti facti de capiendo Emericum de Friscobaldis et socios suos, obmissis senescallo Vasconiæe et aliis officialibus, ubi sunt tot nobiles personæ et potentes, fuit facta tam simplici personæ sicut est Johannes Squiroli; et hoc 
as far as can be judged from the entries on the Liberate Rolls, the sums borrowed of them during this reign were comparatively small.

In the fourth year, the Bardi received an order upon the Exchequer for Notices of 2,000l. which they had lent to forward certain important affairs of the tracted durKing's. ${ }^{i}$ ing this reign.

In the sixth year, 2,000l. are paid to the Bardi in compensation for losses sustained by delay in recovery of the loans which the King had taken of them since his accession. $k$

In the same year, Antonio Pessagno, a Genoese, is commissioned to raise a loan for the King of twenty thousand pounds. ${ }^{1}$

We learn from the "Fodera" that, in the ninth year, the Bardi of Florence advanced money (it does not appear to what amount) upon a subsidy levied by the King upon his subjects in the Duchy of Guienne; and the issues of the same are assigned to them in payment. $m$

In the tenth year, 7,787l. are ordered to be paid to the Bardi from the

quasi in despectum habuerunt, et quasi fere dictum negotium, nisi nos interfuissemus, derelictum, dicto Johanni Squiroli dimisissent."

In dorso. "Reverendo in Christo patri domino J. Dei gratia Norwycensi episcopo, per suos clericos, Johannem Guicardi et Aubertum Medici."

The following is the copy of the writ referred to in the foregoing letter; to which it is annexed :

“ Edwardus, Dei gratia, Rex Angliæ, dominus Hyberniæ et Dux Aquitaniæ, senescallo suo Vasconiæ vel ejus locum tenenti, salutem. Licet nos nuper, credentes mercatores de societate Friscombaldorum de Florentia erga nos in aliquibus transgressos fuisse, ordinassemus de consilio nostro quod mercatores de eadem societate aut bona eorum in regno nostro ab eodem regno non elongarentur, quousque inde plena justitia facta est; et vobis mandassemus quod in dicto ducatu taliter provideretis quod mercatores de dicta societate, in eodem ducatu commorantes, se ant bona sua ab eodem ducatu non elongarentur, quousque aliud inde ordinassemus : quia, tamen, jam sumus de dictis mercatoribus bene assecurati de habendo ab eis bonam et fidelem responsionem de hiis de quibus nobis tenentur respondere; vobis mandamus quod mercatores de dicta societate in ducatu prædicto occasione mandati nostri prædicti non molestetis in aliquo seu gravetis; et, si ipsos ea occasione arrestaveritis in manum nostram, tunc ipsos dearrestari et bona et catalla sua sic capta eis restitui faciatis indilate. T. me ipso, apud Alnewyke, xxvij. die Julii, anno regni nostri quinto."

"Per breve de privato sigillo."

i Annexed Extracts, cxxxv.

1 Rym. Fœd. vol. ii. p. 214.

k Ibid. cxxxvi.

m Ibid. p. 296. 
receipts of the sixteenth granted by the laity, and the tenth by the clergy. The sum had been lent by them to different persons, and on various occasions."

In the same year, they have a bill upon the Treasury for 4,000 marks, the King's gift, in consideration of delay in the payment of his debts to them.o

In the eleventh year, Antonio Pessagno, of Genoa, is commissioned to raise a loan for the King of 20,000 marks, in Aquitaine, and to assign the issues of certain lands of the Duchy in payment. $p$

In the fourteenth year, the Bardi receive a portion of $2,240 l$. which they had undertaken to pay to Aymer de Valence, Earl of Pembroke, for his wages, when he served Edward the First, in the Scotch war. $q$

And in the seventeenth year, 3,000 marks, in florins, were paid jointly by the Bardi, Scali and Peruzzi, to the constable of Bourdeaux, on loan, for the King's business. ${ }^{r}$

Transactions of the Italians as the King's money-lenders, during the reign of Edward III.
Advance in the system of raising

XI. The history of the reign of Edward the Third, if it were justly written, would set financial affairs before us most conspicuously; for it is a history of wars, and to prolonged warlike enterprises money was not less indispensable then than it has been proved to be in our own day. A complete exposition of them, for this period, would display the true power and the progress of the country; might disclose some springs of its present greatness ; and might afford a clue to principles in government concealed from the eyes of statesmen and philosophers by the deficiency of evidence complained of in our early annals. The chronicles of the time, excellent as they are, afford little information upon such a subject. What we seek for remains yet to be extracted from the national archives : and, until their exact contents have been made known, the attempt to procure the materials necessary for such a purpose must cause an excessive application of time and labour, and must at last be ineffectual.

What deserves particular attention, from its connexion with the present subject, is the advancement which was now made in the system of raising

\footnotetext{
n Annexed Extracts, cxLys.

- Ibid. cxLVIII.

p Rym. Fod. vol. ii. p. 346.

Annexed Extracts, crxir.

$r$ Annexed Extracts, crxiv, crxv, crxvr.
} 
loans among the King's native subjects. The practice had originated early. Loans among In the time of John, abbots of the Cistercian order were commissioned to the King's obtain loans for the King; and the Archbishop of Canterbury and the Justitiary were sureties. $s$ It was occasionally pursued in the reigns of Edward the First and his successor; and even the persons from whom the loan was required and the sums expected were sometimes specified in the commissions. $^{t}$ Yet we find no instances of such demands having been enforced by royal authority. But, in the reign of Edward the Third, examples of both voluntary and compulsory loans, and of much larger amounts than before, are frequent. In his tenth year, commissioners are empowered to contract a loan in his name, to the amount of $60,000 l$. sterling; and he submits himself to the coercion of the Pope's court for the fulfilment of his obligation. The same commissioners have other letters, in the same words and of the same date, authorizing them to borrow in the King's name, further sums of $50,000 l$., $40,000 l$., $30,000 l$., and $20,000 l .{ }^{\mathrm{u}}$ In his twelfth year, while he is at Antwerp, officers are appointed to raise a loan of 100,000 gold florins of Florence : ${ }^{\mathrm{x}}$ and numerous other instances might be cited. In these commissions there is nothing to induce a supposition that compulsion was used in procuring the required sums : and probably very little eagerness was exhibited by merchants or others to advance money upon the security offered. But less moderate measures were afterwards adopted. We learn from a close writ, of the twenty-first year of Edward the Third, that merchants had been summoned before the King's council to treat respecting a loan; specified sums were exacted from them individually, and the writ referred to shews that these requisitions were enforced; for it is a summons to one of the parties to pay at an appointed term his portion of the loan, which was one hundred pounds, on penalty of the forfeiture of all his goods. $y$ An examination of the Close Rolls for this period would doubtless disclose many other instances of a like arbitrary exercise of royal authority.

With respect to the operations of the Italians in this reign (the period of Barrenness their greatest activity) the Liberate Rolls are found to be comparatively of the Libethis reigu.

s Rot. Pat. vol. i. p. 14.

u Ibid. vol. ii. p. 942 .

VOL. XXVIII. t Rym. Fœed. vol. ii. p. 617.
x Ibid. p. 1060 .
y Ibid. vol. iii. p. 121. 
barren of information. And this deficiency may be attributed to the following causes : First, that the writs enrolled on them, being simply orders upon the Exchequer in favour of parties therein named, and the bulk of the debts contracted with the Italians by Edward the Third having, as is subsequently shewn, been left unpaid, no estimate can be formed, upon their authority, of the amount of loans received. Secondly, that orders upon the Exchequer were now less frequent than before, because the office of the Wardrobe, which followed the King's person, monopolized much of the business which had formerly been executed there. To the particular payments made through the Wardrobe the Chancery Rolls afford no clue. The keeper, from time to time, received bills for large amounts, of ten or twenty thousand pounds, and upon these he drew what sums were required in his office. Its convenience as a medium of expenditure was so much experienced by Edward the Third (and perhaps the more from his frequent absence from England) that, from the twentieth year of his reign, it had become the ordinary channel of government payments. From this date the Liberate Rolls consequently lose their value, and they contain little more than orders for payment of the annual salaries of the principal officers of the Crown.

Queen Isabella assisted by the Italian moneylenders.
There is some reason to believe that the expenses of the expedition which placed Edward the Third upon the throne were partly supplied out of the funds of the Italians. Immediately after the deposition of Edward the Second, a bill of 20,000l. was drawn upon the Exchequer, for discharge of debts contracted by Queen Isabella with merchants abroad. ${ }^{z}$ I have not succeeded in discovering the account of the keeper of her wardrobe, by whose hands the payments were made. But it is evident that she had had dealings with the Italians; for on the fifteenth of December in the last year of Edward the Second, when the reins of government were already in her hands, the treasurer was commanded to deliver thirteen hundred pounds to the keeper of her Wardrobe, to pay off a loan of that amount received from the Bardi, while the Queen was in foreign parts. ${ }^{\text {a }}$ Within a month after the accession of Edward the Third, the same company received a bill upon a Annexed Extracts, cLxvir. 
the Exchequer for 2,000l. for an equal sum which the Queen had borrowed of them abroad; and which, as the writ of Liberate states, was paid into her own hands. ${ }^{b}$

The Bardi and Peruzzi of Florence are particularly distinguished at this period; whilst the numerous companies occasionally mentioned under the reign of Edward the First, disappear from view. Probably the narrowness of their escape from hazardous engagements formed with that monarch, had rendered them cautious of venturing their capital in such speculations; and they confined themselves to the safer dealings with religious houses and private persons, among whom the active events of this reign would procure them plentiful opportunities of employing their funds advantageously.

It appears from letters patent dated on the 25th of May in the third year, Notices of that Edward the Third granted to the Bardi 2,000l. in compensation for the more their losses in advancing 5,000 marks, on loan, for the expenses of his pas- loans consage into France, and 7,000l. to be delivered to John of Hainault and ingthis reign. others of that country, for their service in the King's expedition against the Scots. $c$

In the fourth year, the Bardi undertook to supply the King with $20 l$. daily, for the space of one year ; and all the customs of the realm were assigned to them in payment. ${ }^{\mathrm{d}}$

In the following year, the same company are represented as having engaged to provide 1,000 marks every month, for one year, towards the expenses of the household; and the new and old customs in London and elsewhere are assigned to them for satisfaction of the debt. ${ }^{e}$

In the sixth year, the Bardi advanced 10,000l. to be delivered to Reginald Earl of Gueldres, as the marriage portion of Eleanor the King's sister; and they received the King's letters of acknowledgement for the debt. ${ }^{\text {f }}$

In the same year, the King promised to pay them 4,000 marks, of his gift, to compensate their losses occasioned by the non-payment of the loans they had advanced, or had procured from others, for his use. 5
b Annexed Extracts, cLXviII.
c Rym. Fœd. vol. ii. p. 764.
d Cal. Rot. Pat. p. 108.
e Ibid. p. 113.
f Ibid.
g Rot. Pat. 6 Edw. III. part 1. m. 9. 
In the eleventh year, they received a bill for 10,000l. which they had paid, at the King's request, to divers persons in foreign parts, to expedite urgent business which concerned the King."

In the same year, writs were directed to the Treasurer, commanding him to deliver two sums to the Peruzzi, one of $2,000 \mathrm{l}$. paid by them in foreign parts, on certain secret affairs concerning the state; ${ }^{i}$ and another of the large amount of 35,000l. the greater part of which they had already advancd on loan, and the remainder they had undertaken shortly to provide. $k$

In the thirteenth year, as appears from letters printed in the Fodera, the King borrowed 140,000 florins of gold from a Lucchese merchant, a sum equal to 24,500l. sterling. The letters of obligation are dated at Antwerp, in May, and payment is promised on the first of November, at Bruges. ${ }^{1}$ A peculiarity respecting the securities which were offered on this occasion has already been pointed out.

In the fourteenth year, it appears that after audit of the accounts of two merchants of the names of Gabriel de Monte Magno and Mathew de Canachoen, and who from another instrument are ascertained to belong to the company of the Leopardi, and after deduction made of sums already paid them, the King still remains in their debt 65,982 florins $(11,546 l$. 17s. sterling) for sums advanced by them on loan. ${ }^{m}$

It is to be observed that, from the fourteenth to the twenty-first years of Edward the Third, the annexed extracts afford no instance of important transactions with the Italian merchants ; although their resources must have been exercised to the utmost, in order to supply the heavy demands of the French war.

In the twenty-first year, the Bardi received $150 l$. in part payment of the immense sum of 50,493l. for which they had the King's letters of obligation. ${ }^{\mathrm{n}}$

From this period the Liberate Rolls cease to afford continuous evidence respecting the loans with which Edward the Third was supplied by these adventurous foreigners. One instance only of importance is collected from

h Annexed Extracts, cLxxxıx.

I Rym. Fœd. vol. ii. p. 1081. i Ibid. cxcı.

m Ibid. pp. 1108, 1143. k Ibid. cxcın.

n Annexed Extracts, cciv. 
them, of a sum of $23,600 l$. which was borrowed of a company of Lucchese merchants in the twenty-sixth year. ${ }^{\circ}$

But matters had now reached an extremity with the most wealthy of the Italian companies, who had hitherto proved a sheet-anchor to the govern- Ruin of the ment in its exigencies, and had advanced so much the commerce of the companies of kingdom, where they had maintained themselves by the experienced benefit Italian merof their power and intelligence. Edward's successes came too late to com- England. pensate the losses of the prolonged and doubtful war by which they were preceded: and the circumstances in which he was still engaged, far from enabling him to clear himself of the debts with which he was encumbered, obliged him largely to augment them. The Bardi and Peruzzi, who had assisted him to the full extent of their capital, now found the payment of their demands constantly deferred; and, no longer able to support their commercial engagements, they finally became bankrupts. We have the story of their ruin delivered by Giovanni Villani, a contemporary writer :

"At the period of the war between the Kings of France and England, the companies of the Bardi and Peruzzi, of Florence, were the King of England's merchants. All his revenues and wools came into their hands, and they furnished from them all his expenses. But the expenses so much exceeded the revenues that the King of England, when he returned home from the war, found himself indebted for principal, assignments and rewards, to the Bardi more than 100,000 marks sterling, and to the Peruzzi more than 135,000 marks. Of these sums a considerable portion consisted in assignments which the King had made to them in times passed: but they were rash enough, whether from covet of gain or led on by the hope of recovering the entire debt, to give them up, and entrust all their own property and that of others in their keeping, to this one Prince. And observe, that a large part of the money they had lent was not their own capital, but had been borrowed by them or received on trust from fellow-citizens and strangers. And great danger thence accrued both to them and to the city of Florence. For not being able to answer the calls of their creditors in England and Florence, and elsewhere, where they trafficked, they lost their credit on all sides, and became bankrupts; and especially the Peruzzi. Yet they avoided

- Annexed Extracts, ccv. 
complete ruin by their possessions in the city and territory of Florence, and by the great power and rank which they held in the republic. This failure, and the expenses of the state in Lombardy, greatly reduced the wealth and condition of the merchants and traders of Florence, and of the whole community. For the Bardi and Peruzzi had held so large a share of the commerce of Christendom, that upon their fall every other merchant was suspected and distrusted. Our city of Florence, in consequence, received a shock, such as had not been experienced before for many years. But, to add to the reverses of these companies, the King of France caused them and other Florentines throughout his dominions to be pillaged of all their merchandize and property, both on account of the bankruptcy and because we had been obliged to borrow money of his subjects, to expend on our affairs in Lombardy and Lucca : and this caused the ruin of many other smaller companies of Florence, as we shall afterwards make mention." $p$

It would be not uninteresting to trace the effects of this catastrophe upon the merchants of England, who must have been implicated to some extent : but the want of facilities for the necessary research discourages the attempt, and will, I hope, excuse the omission it occasions; while it obliges me to add another to the many imperfections which must be charged upon this memoir. 


\section{EXTRACTS FROM THE LIBERATE ROLLS PRESERVED IN HER MAJESTY'S RECORD OFFICE, IN THE TOWER OF LONDON.}

I.

12 Hen. III. m. 6.-Liberate pro mutuo facto in curia Romana.-Rex thesaurario et camerariis suis, salutem. Liberate de thesauro nostro Burgundioni Bacarelli, Restoro Jacobi, Leonardo Hubertini, Jacobo Pieri et sociis suis, mercatoribus Senensibus, ccc marcas, quas commodaverunt magistro Alexandro archidiacono Salopensi et magistro Waltero de Cantilupo, ad negotia nostra in curia Romana expedienda. Teste J. Bathonensi episcopo, apud Welliam, $v$ die Maii, anno regni nostri xijo.

II.

12 Hen. III. m. 6.-Liberate pro pluribus,-Liberate .... Michaeli de Bauderaue et Thomæ de S. Quintino trescentas marcas, ad opus Thurchi Clarmontensis, Herminii Bencevendi, Uguolini Beimitii, Reineri Orlandi, Piccolomini Ultramontes, Reinerii Poncii, Alberti Petri et Thomasini Ancontini, mercatorum Senensium, quas commodaverunt magistro Waltero Crespin et magistro Willielmo de Grenlawe, nunciis nostris existentibus in curia Romana, ad negotia nostra in eadem curia expedienda. T. R. apud Westmonasterium, viij die Maii.

III.

12 Hen. III. m. 4.-Liberate pro prastito facto in curia Romana.-Rex, etc. Liberate de thesauro nostro Reinero Salumberre, ad opus suum et ad opus Ragonensis Albertini, Bonaventuri de Pace, Montanelli Morlani, Lamberti Guardadei, Bartholomei de Mancino, Hugolini Gentilis et Bernardi Alamandi, mercatorum Senensium, quingentas et xxx marcas, quas commodaverunt magistro Waltero Crespin et magistro Willielmo de Grenlawe, ad negotia nostra in curia Romana expedienda. Liberate etiam eidem Reinero ad opus suum et ad opus prædictorum Bonaventuri, Lamberti Ragonensis, Hugojini Gentilis, Bartholomei Cirioli, Boncompago Guiducii et Bartholomei de Mancino, mercatorum Senensium, centum marcas, quas commodaverunt Alexand̉ro de Suereford archidiacono Salopensi et magistro Waltero de Cantilupo, ad negotia nostra in eadem curia expedienda. Teste Rege, apud Westm. xxiiij die Junii. 
IV.

12 Hen. III. m. 3.-Liberate pro prestito facto in curia Romana.-Rex, etc. Liberate de thesauro nostro Boncompago Guiducii, Senensi, ad opus suum et sociorum suorum, mercatorum Senensium, sexcentas et quaterviginti marcas, quas commodaverunt magistris Waltero Crespin et Willielmo de Grenlawe, nunciis nostris existentibus in curia Romana, ad negotia nostra ibidem expedienda. Teste Rege, apud Westm. xx die Junii.

V.

17 Hen. III. m. 6.-Liberate pro pluribus.-Rex, etc. Liberate . . . . Compaigno et sociis suis, mercatoribus de Florentia, sexcentas libras, quas Petrus Saracenus et Petrus Grimbaud mutuo ceperunt ab eis, in curia Romana, ad negotia nostra ibidem expedienda. Liberate etiam eisdem mercatoribus quinquaginta libras, de dono nostro, pro dampnis et expensis suis.

VI.

21 Hen. III. m. 15.-Rex, etc. Liberate de thesauro nostro Angelerio Solaficiis et sociis suis, mercatoribus Senensibus, quadringentas marcas, quas commodaverunt magistro Roberto de Sumercot ad negotia nostra in curia Romana expedienda : retentis penes vos litteris nostris, mutuum illud testificantibus; et omnibus aliis instrumentis inter ipsum magistrum Robertum et prædictos mercatores super eodem mutuo confectis. T. R. apud Windesoram, viij die Novembris.

\section{VII.}

21 Hen. III. m. 12.-Rex, etc. Liberate de thesauro nostro, in crastino Ascensionis Domini, anno regni nostri xxj, Vermeyo Laurencii et Reynero Orlandi, mercatoribus Romanis, sexcentas et lx marcas, quas dilecti et fideles nostri magister Symon de Sterland et Petrus Sarracenus mutuo ab eis ceperunt, pro negotiis nostris in curia Romana expediendis : recepto et retento in manu vestra instrumento, quod penes se habent, de prædicto mutuo. T. R. apud Westm. xij die Februarii.

VIII.

21 Hen. 1II. m. 6.-Rex, etc. Liberate sine dilatione Bartholomeo et Hugoni, Senensibus mercatoribus, vel certo eorum nuncio has litteras nostras vobis deferenti, $\mathbf{x l}$ marcas, quas commodaverunt magistro Willielmo de Kylkenny ad negotia nostra in curia Romana expedienda. Ita videlicet quod, antequam denarios illos ei liberaveritis, tam litteras nostras patentes procuratorias de mutuo illo quam litteras ipsius magistri Willielmi de ipso contractu ab eo recipiatis. T. R. apud Windesoram, xïij die Julii. 
IX.

23 Hen. III. m. 22.-Liberate de mutwo acquietando.-Rex, etc. Liberate de thesauro nostro, sine dilatione, Ranuchio Birboti et sociis suis, mercatoribus Senensibus, L marcas, quas magister Alexander le Setuler mutuo cepit ab eis, in curia Romana, ad negotia nostra ibidem expedienda. T. R. apud Westm. $\mathrm{x}$ die Januarii.

$\mathrm{X}$.

25 Hen. III. m. 19.-Liberate pro Ranuchio Barboti.-Rex, etc. Liberate de thesauro nostro Ranuchio Barboti vel Hugoni magistri Pagani, mercatoribus Senensibus, c solidos et $\mathrm{L}$ marcas, quos commodaverunt Priori de Theford et Nicholao de Boleville, ad negotia nostra in curia Romana expedienda. T. R. apud Westm. xxvj die Decembris.

Recipiatis etiam ab eis instrumenta quæ haberent de prædicto mutuo facto.

XI.

25 Hen. III. m. 2.-Rex, etc. Liberate de thesauro nostro Clario Hugelino, mercatori de Florentia, ccc marcas, liberandas nunciis nostris qui proximo venturi sunt ad curiam Romanam . . . . Imperatoris, ad quædam negotia nostra ibidem expedienda. T. R. apud Westm. xxv die Octobris.

\section{XII.}

26 Hen. III. m. 19.-Rex, etc. Liberate de thesauro nostro Ranuchio Barboti, mercatori Senensi, c marcas, quas liberavit dilecto clerico nostro Eadwardo filio Odonis, liberandas nobis in garderoba nostra ad expensas nostras, per præceptum nostrum. Liberate etiam eisdem alias c marcas, pro xj marcis margaritarum emptarum a diversis mercatoribus et traditarum per præceptum nostrum eidem clerico nostro, ad plures operationes nostras quas eidem Edwardo injunximus faciendas, etc.

\section{XIII.}

28 Hen. III. m. 16.-Pro mercatoribus Florentinis et Senensibus.-Rex, etc. Liberate de thesauro nostro, videlicet de denariis quos recepistis de Aaron, Judæo Eboracensi, Ranuchio Barboti, mercatori Senensi, et Felino Gwill'i, mercatori Florentino, sexcentas marcas, pro sexcentis marcis quas habere facient magistris Henrico de Secus' et Alexandro le Seculer, ad negotia nostra in curia Romana expedienda. T. R. apud Westm. viij die Januarii.

\section{XIV.}

28 Hen. III. m. 10.-Liberate pro mercatoribus Florentinis et Senensibus.-Rex, etc. Liberate de thesauro nostro Fulingo Gwill'i, Ranuchio Barboti, Clario Hugelini et vol. XXVIII. 
Hugoni Magistri Pagani, civibus et mercatoribus Florentinis et Senensibus, vel uni eorum, sine dilatione, septingentas marcas, pro septingentis marcis quas liberari fecerunt magistris Alexandro le Seculer et Henrico de Secus', ad negotia nostra in curia Romana expedienda: retentis penes vos litteris nostris patentibus quas eisdem mercatoribus fieri fecimus, una cum aliis litteris nostris patentibus de Dc marcis quas eis liberastis in Januario. T. R. apud Radyng, xv die Maii.

XV.

29 Hen. III. m. 6.-Liberate pro mercatoribus de Florentia.-Rex, etc. Liberate de thesauro nostro Aymerico Cosse et Mainetto Robertin c libras, pro c libris quas Spilettus et socii sui, mercatores Florentini, liberaverunt magistro Laurentio de S. Martino ad expensas suas in curia Romana acquietandas. T. R. apud Westm. xiij die Junii.

\section{XVI.}

30 Hen. III. m. 1.-Liberate pro Claro, mercatore Florentino.-Rex, etc. Liberate de thesauro nostro Claro, mercatori Florentino, quingentas marcas in crastino Animarum, anno etc. $\mathrm{xxxj}$, pro quingentis marcis quas fecit habere Thomæ de Sabaudia, quondam comiti Flandriæ, de annuo feodo suo quingentarum marcarum. T. me ipso, apud Westm. $\mathrm{xx}$ die Octobris.

\section{XVII.}

31 Hen. III. m. 15.-Liberate pro Claro de Florentia.-Rex, etc. Liberate de thesauro nostro Claro, mercatori Florentino, $\mathrm{c}$ marcas, de quingentis marcis quas liberavit Thomæ de Sabaudia, quondam Comiti Flandriæ, per præceptum nostrum; de quibus quingentis marcis Aaron de Eboraco Judæus solvit [quadringentas marcas?] eidem Claro per præceptum nostrum. T. R. apud Rading, xxxj die Octobris.

\section{XVIII.}

31 Hen. III. m. 5.-Liberate pro mercatoribus Florentinis.-Rex, etc. Liberate de thesauro nostro Felino et sociis suis, mercatoribus Florentinis, quingentas marcas, de primis denariis qui venient ad scaccarium nostrum S. Michaelis, quas ab eis mutuo recepimus ad stipendia servientium nostrorum ad arma solvenda. T. R. apud Westm. $\mathrm{x}$ die Junii.

\section{XIX.}

32 Hen. III. m. 9.-Liberate pro mercatore Florentino.-Rex, etc. Liberate de thesauro nostro Felino, mercatori Florentino, cccl libras, quas liberavit P. Chaceporc' custodi garderobæ nostræ, ad expensas nostras : retentis penes vos litteris nostris patenti- 
bus, quas habet, mutuum prædictum protestantibus. T. me ipso apud Merton, xxij die Aprilis.

XX.

34 Hen. III. m. 8.-Liberate pro Felino Florentino.-Rex, etc. Liberate de thesauro nostro Dentaduito fratri Felini, quondam mercatoris Florentini, c libras, in quibus eidem Felino tenebamur de prestito nobis facto per diversas particulas, per litteras nostras patentes quas penes nos retinuimus. T. R. apud Westm. xxvij die Aprilis.

\section{XXI.}

34 Hen. III. m. 2.-Liberate pro mercatoribus Senensibus, de censu Papa.-Rex, etc. Liberate de thesauro nostro Bernardo Prosperin, Frederico Rouland, Jacobo Offreduch', Jacobo Hugethini et Gentili Gentil', mercatoribus Senensibus, quingentas marcas. Liberate etiam de thesauro nostro Mainetto Spineti, Bevenuto Will'i, Hugani Gilberti, Hugoni Simonetti et Gerardo Ricobaldi, mereatoribus Flerentinis, alias quingentas marcas, pro mille marcis quas domino Papæ solverunt pro nobis de termino S. Michaelis, anno etc. xxxij, de annuo censu mille marcarum quas percipit ad scaccarium nostrum. Receptis ab eisdem mercatoribus litteris nostris patentibus pecuniam memoratam testificantibus. T. R. ap. Westm. ix die Maii anno, etc. xxxiij.

\section{XXII.}

34 Hen. III. m. 2.-Liberate pro Tholosano, mercatore Florentino.-Rex, etc. Liberate de thesauro nostro Tholosano, mercatori Florentino, et sociis suis Dece marcas, quas mutuo tradiderunt dilecto et fideli nostro S. de Monte Forti comiti Leycestriæ, in Wasconia, ad castra nostra de Frunzac, Burgo, et Miro Monte, inde munienda et custodienda. Liberate etiam eidem Tholosano cc marcas, quas liberavit Waltero de Bradel custodi garderobæ Reginæ nostræ, ad expensas ejusdem Reginæ acquietandas. Liberate etiam eidem $\mathrm{L}$ marcas ad expensas suas, de dono nostro. Recipientes ab eodem mercatore litteras nostras patentes, quas habet, de præfatis Dcec marcis. T. R. apud Westm. xxiij die Octobris.

\section{XXIII.}

37 Hen. III. m. 7.-Liberate pro Bernardo Persperin et aliis mercatoribus.-Rex, etc. Liberate de thesauro nostro, sine omni dilatione, Bernardo Persperin, mercatori Senensi, et Amanatto Spineti, mercatori Florentino, ccce marcas bonorum, novorum, et legalium sterlingorum, quas ab eis, pro se et Alebrando Alebrandi et Ruskitello Cambii, mutuo recepimus in Quadragesima, anno etc. xxxvij : receptis ab eis litteris nostris patentibus et litteris patentibus Johannis Maunsell præpositi Beverlacensis, Petri Chaceporc archidiaconi Wellensis, magistri Willielmi de Kilkenni archidiaconi Coventrensis, 
Johannis de Gray, Philippi Luvel et Henrici de Wingham, mutui illius obligatoriis. T. R. apud Westm. xix die Martii.

\section{XXIV.}

37 Hen. III. m. 5.-Liberate pro Bernardo Persperin.-Rex, etc. Liberate de thesauro nostro, sine dilatione, Bernardo Persperin, mercatori Florentino, cx libras, quas mutuo liberavit magistro Roberto Anketin in curia Romana, ad quasdam litteras papales ad opus Regis impetrandas. T. R. apud Westm. xij die Maii.

\section{XXV.}

38 Hen. III. m. 7.-Liberate pro mercatoribus de Sena.-Rex, etc. Liberate de thesauro nostro Bernardo Persperin, Alebrando Alebrandini et sociis suis, mercatoribus Senensibus, xl marcas, quas magister Nicholaus de Plinton ab eis mutuo recepit, ad negotia nostra quæ ei injunximus in partibus transmarinis expedienda: receptis prius ab eisdem mercatoribus litteris nostris patentibus et litteris prædicti magistri Nicholai mutuum illud testificantibus. T. Alianora Regina nostra et Ricardo comite Cornubiæ, apud Westm. $\mathbf{v}$ die Novembris.

\section{XXVI.}

38 Hen. III. m. 6.-Liberate pro Maynetto Spine et sociis suis.-Rex, etc. Liberate de thesauro nostro Maynetto Spine, Ruskitello Cambii et sociis suis, mercatoribus Florentinis, illas mille marcas quas recepistis de thesauro nostro Hiberniæ, pro mille marcis quas dilecta consors nostra, Alianora Regina Angliæ, eb eis mutuo recepit, ad negotia nostra et regni nostri utilitatem expedienda. T. ut supra, apud Westm. xxvijj die Januarii.

\section{XXVII.}

39 Hen. III. m. 11.-Liberate pro Aldebrando Aldebrandini et sociis suis, mercatoribus. -Rex, etc. Liberate de thesauro nostro Aldebrando Aldebrandini et sociis suis, mercatoribus Senensibus, ad scaccarium nostrum Paschæ, anno etc. xxxix, cxl marcas, de quibus promiserunt mutuare dilecto clerico nostro magistro Nicholao de Plumpton, profecturo in nuncium nostrum ad curiam Romanam, centum marcas, in partibus transmarinis, ad negotia nostra in præfata curia expedienda; et residuas xl marcas mutuaverunt eidem clerico nostro, ad negotia nostra expedienda, quando alias ivit in nuncium nostrum ad eandem curiam: quas quidem cxl marcas Philippus Lovell et Edwardus de Westmonasterio manuceperunt reddere pro nobis prædictis mercatoribus. T. R. apud Westm. xx die Februarii. 


\section{XXVIII.}

39 Hen. III. m. 10.-Liberate pro Aldebrando Aldebrandini.-Rex, etc. Liberate de thesauro nostro, sine dilatione, Aldebrando Aldebrandini, mercatori Senensi, ccc marcas, quas Guido de Russillun, quondam clericus noster, mutuo recepit, nomine nostro, per litteras nostras patentes, in curia Romana, a Bonefacio Bonsegnur et Bonaventuro Bernardini, mercatoribus, sociis prædicti Aldebrandi, ad quæedam ardua negotia nostra prosequenda in curia prædicta. Et, cum prædictas ccc marcas præfato Aldebrando pacaveritis, ab eo recipiatis prædictas litteras patentes. T. R. apud Westm. vj die Martii.

\section{XXIX.}

39 Hen. III. m. 9.-Liberate pro Lamberto de Puteo et Petro Andrea de Luka [Lucca]. -Rex, etc. Liberate de thesauro nostro Lamberto de Puteo et Petro Andreæ de Luka, civibus Baionensibus, ccclxx marcas, ij solidos, et iij denarios, in quibus eis tenemur pro mutuo quod nobis fecerunt per manus Simonis de Monte Forti comitis Leycestriæ, Petri de Sabaudia et Willielmi de Cantilupo. Liberate etiam eisdem civibus de thesauro nostro $L$ marcas, de dono nostro: facta tamen prius pacatione denariorum in quibus tenemur per sacramentum nostrum prædicto comiti et, similiter, diversis mercatoribus. Et recipiatis a prædictis civibus litteras nostras patentes, quas habent, prædictum debitum testificantes. T. R. apud Windes. viij die Aprilis.

\section{$\mathrm{XXX}$.}

40 Hen. III. m. 14.-Liherate pro Denteyto mercatore.-Rex, etc. Liberate de thesauro nostro Dentayto, mercatori nostro, centum marcas, pro laudabili servitio nobis impenso, de dono nostro. T. R. apud Wodestok, $\mathrm{x}$ die Februarii.

\section{XXXI.}

43 Hen. III. m. 8.-Pro Percevallo de Luka [Lucca].-Rex, etc. Liberate de thesauro nostro Percevallo de Luca xxx libras, quas dilectus et fidelis noster Simon de Monte Forti comes Leycestriæ, custos castri nostri Wyntoniæ, ab eo mutuo recepit in autumpno proximo præterito, et liberavit custodibus operationum prædicti castri ad easdem operationes inde faciendas; sicut idem comes coram nobis recognovit. T. R. apud Westm. xxix die Octobris, anno regni nostri xliij.

Per magnates de consilio Regis.

\section{XXXII.}

43 Hen. III. m. 8.-Pro Petro Andrea de Luka [Lucca].-Rex, etc. Liberate de thesauro nostro Petro Andreæ de Luka [Lucca], mercatori Bayonensi, iij libras, quas mu- 
tuo tradidit dilectis et fidelibus nostris Simoni de Monte Forti comiti Leycestriæ et Petro de Sabaudia, cum ultimo fuimus in Vasconia, pro negotiis nostris apud Bayoniam expediendis. Ita quod, facta solutione eidem mercatori de pecunia predicta, decidant eidem comiti Leycestriæ iiij libræ de debitis in quibus eidem tenemur per litteras nostras patentes; eo quod prædictæ iiij libræ eidem comiti computantur in summa prædictorum debitorum, contentorum in prædictis litteris patentibus. T. R. apud Westm. iij die Novembris.

Per magnates de consilio.

\section{XXXIII.}

43 Hen. III. m. 8.-Pro Jacobo Dananzaci et sociis suis.-Rex, etc. Liberate de thesauro nostro Jacobo Danenzaci, Rucco Cambii, Berardo Ricobaldi, civibus et mercatoribus Florentinis, et Aldebrando Aldebrandini, civi et mercatori Senensi, mille et trescentas marcas, in partem solutionis pecuniæ quam nobis mutuarunt in acquietationem arreragiorum annui census quem dominus Papa percipit ad scaccarium nostrum; pro qua quidem pecunia eisdem mercatoribus solvenda Prior et conventus Westmonasteriensis se pro nobis nomine fidejussorio obligarunt. T. R. apud Merton', etc. ut supra.

Per etc. ut supra.

\section{XXXIV.}

43 Hen. III. m. 7.-Pro Paulo Albertini et sociis suis.-Rex, etc. Liberate, de denariis venientibus de Wintonia, Paulo Albertini, Ermineo Erminei et Bencin Consilii, civibus et mercatoribus Senensibus, pro se et sociis suis, quingentas et quinquaginta libras, quas nobis mutuo tradiderunt super quædam jocalia nostra aurea et argentea, signata sigillis dilectorum clericorum nostrum Johannis Maunsell thesaurarii Eboraci et Eduuardi de Westmonasterio. Et, facta solutione prædicta, recipiatis ab eisdem prædicta jocalia et litteras nostras patentes quas inde habent. T. R. apud Merton', xiij die Januarii.

\section{XXXV.}

43 Hen. III. m. 5.-Pro Jacobo Dananzaci et sociis suis.-Rex, etc. Liberate de thesauro nostro, sine dilatione, de denariis qui nuper venerunt de Abbatia de Waverley, quos mutuo cepimus de pecunia dilecti fratris nostri A. Wintoniensis electi, Jacobo Dananzaci, Rucco Cambii, Berardo Rikebaldi, civibus et mercatoribus Florentinis, et Aldebrando Aldebrandini, civi et mercatori Senensi, mille marcas, qua eis restant reddendæ de pecunia quam nobis mutuarunt in acquietationem arreragiorum annui census quem dominus Papa percipit ad scaccarium nostrum; pro qua quidem pecunia eisdem mercatoribus solvenda Prior et conventus Westmonasterii se pro nobis nomine fidejussorio obligarunt. Et, facta solutione dictarum mille marcarum, recipiatis a prædictis 
Priore et conventu litteras nostras obligatorias, quas habent, de solutione pecuniæ supradictæ, et similiter jocalia nostra quæ, loco pignoris, sunt in deposito in abbatia sua penes priorem et conventum, pro pecunia eadem. T. R. apud Westm. xiij die Maii.

\section{XXXVI.}

43 Hen. III. m. 3.-Pro Arnaldo de Sena et sociis suis.-Rex, etc. Liberate de thesauro nostro, in scaccario S. Michaelis, Ernaldo de Sena et sociis suis, mercatoribus Senensibus, $\mathrm{c}$ libras, in partem solutionis sexcentarum librarum in quibus eis tenemur : recipientes ab eisdem litteras suas patentes solutionem illam testificantes. T. R. apud Windesoram, viij die Augusti.

\section{XXXVII.}

43 Hen. III. m. 2.-Pro Nicholao de Hadlou.-Rex, etc. Allocate Nicholao de Hadlou custodi episcopatus Wintoniensis, in exitibus ejusdem episcopatus, tria milia marcarum, quæ liberavit Petro de Sabaudia, Rucco Cambii, Luterio Bonycase, civibus et mercatoribus Florentinis, pro arreragiis feodorum Thomæ de Sabaudia quondam comitis Flandriæ, Amadei quondam comitis Sabaudiæ, et Bonefacii filii et hæredis ejusdem Amedei; pro qua quidem pecunia dilecti et fideles nostri R. de Clara comes Glovernix, H. le Bigod, Johannes Maunsell, Henricus de Wengham et Robertus Walerand prædictis Petro de Sabaudia et Rucco, et aliis sociis ejusdem Rucci, se pro nobis obligaverunt per litteras suas patentes, apud Cantuariam, die Mercurii ante Mediam Quadragesimam, anno etc. xliij-ac si dicta pecunia ad opus eorumdem pro propriis negotiis suis fuisset. T. R. apud Westm. vj die Septembris.

\section{XXXVIII.}

45 Hen. III. m. 14.-De denariis liberandis Maynetto et Rucco, pro Rege Scotice et Johanne de Britannia, pro extenta comitatus et honoris Richemundice.-Rex custodi episcopatus Dunelmensis, salutem. Mandamus vobis quod de exitibus prædicti episcopatus, sine dilatione, faciatis habere Maynetto et Rucco, civibus et mercatoribus Florentinis, sexcentas marcas, quas nuper nobis mutuarunt; videlicet, centum marcas ad opus Alexandri Regis Scotiæ, pro arreragiis suis centum solidorum, quos a nobis percipere debet singulis diebus, pro expensis suis, quotiens ipsum ad nos venire contingat in Angliam, ad mandatum nostrum; et quingentas marcas ad opus Johannis de Britannia, in partem solutionis mille et sex librarum, sex solidorum et duorum denariorum, pro extenta comitatus et honoris Richemundia. Et computabuntur vobis ad scaccarium. T. R. apud Windes. ij die Januarii. 
Memorandum quod Regina prosequebatur istud breve.

Reddidit breve et vacat, quia aliter inferius per breve de Allocate.

[In the writ here referred to the names of the Italian merchants are omitted.]

\section{XXXIX.}

50 Hen. III. m. 9.-Pro Dentauto, mercatore Florentino.-Rex, etc. Liberate de thesauro nostro Dentaeto de Florentia, mercatori nostro, trescentas et viginti marcas, pro mutuo quod idem Dentaetus fecit . . . . Johanni de Ambilini, quondam domini Papæ capellano, ad negotia nostra in curia Romana per ipsum Johannem expedita, anno etc. tricesimo octavo. Et, facta eidem Dentaeto solutione pecuniæ prædictæ, recipiatis ab eo litteras nostras patentes, quas idem Dentaetus inde habet, pecuniam illam testificantes. T. R. apud Westm. xvii die Martii.

XL.

50 Hen. III. m. 8.-Pro Dentaito de Florentia.-Rex, etc. Mandamus vobis quod, juxta tenorem brevium nostrorum de liberate quæ penes vos habetis ad scaccarium nostrum, faciatis habere dilecto mercatori nostro Dentaito de Florentia et sociis suis, mercatoribus de Florentia, ducentas et quinquaginta libras, in quibus eis tenemur per diversas particulas ad scaccarium prædictum. T. R. apud Westm. xxiiij die Martii.

\section{XLI.}

52 Hen. III. m. 4.-De denariis mutuo receptis ad opus Regis acquietandis.-Rex, etc. Liberate de thesauro nostro venerabili patri G. Wygornensi electo, cancellario nostro, et magistro Thomæ de Wymundeham, thesaurario . . . . . et octo denarios, quos ad opus nostrum mutuo receperunt a Reynerio Abbatis et sociis suis, mercatoribus Florentinis, ad urgentissima negotia nostra inde expedienda . . . . . S. Johannis Baptistæ proximo futurum, de primis denariis quos deferri contigerit ad scaccarium prædictum. Et hoc nullatenus omittatis. T. R. apud Windesoram, . . . . . Junii.

\section{XLII.}

53 Hen. III. m. 11.-Pro Reinerio le Furner et Hugone Pape.-Rex, etc. Liberate de thesauro nostro Reinerio le Furner et Hugoni Pape, et sociis suis, mercatoribus Florentinis, quinquaginta marcas, de gratia nostra speciali ; videlicet, pro dampnis, laboribus, et expensis quas posuerunt circa trescentas marcas, quas nobis ad urgentissima negotia nostra expedienda mutuarunt, perquirendas a manibus collectorum decimæ nostræ, de qua pecuniam illam receperunt. T. R. apud Westm. iiij die Februarii. 


\section{XLIII.}

53 Hen. III. m. 10.-Pro magistro Johanne de Chishull decano S. Pauli Londonice, et aliis in brevi.-Rex, etc. Liberate de thesauro nostro, de primis denariis ad scaccarium nostrum venturis, magistris Johanni Chishull decano S. Pauli Londonensis, cancellario nostro, Thomæ de Wymundeham præcentori Lychfeldensi, thesaurario nostro, et Tydisio de Camilla decano de Wlvernehamtonia, Coventrensis diocesis, trescentas marcas, per manus eorum solvendas Reynerio Abbatis, Hugonetto Simonetti, dicto Mace, et eorum sociis, mercatoribus Londoniæ commorantibus, pro trescentis marcis quas ab eisdem mutuo ceperunt ad opus nostrum, et de quibus liberaverunt per præceptum nostrum Reymundo vicecomiti Turenniæ ducentas marcas, Poncio de Gurdun triginta et sex libras et quinque solidos, de arreragiis annuorum feodorum suorum, et eidem Poncio viginti et quinque libras, quas nuper ei dedimus ad novam militiam suam et sociorum suorum, et magistro Roberto de Beverlaco et sociis suis, custodibus operationum nostrarum Westmonasterii, centum et octo solidos et quatuor denarios, ad easdem operationes. Et hoc pro aliquo mandato nostro vobis directo vel dirigendo nullatenus omittatis. Et, facta solutione prædicta, recipiatis ab eis litteras nostras patentes, quas habent, dictam pecuniam testificantes. T. R. apud Westm. xxiij die Februarii.

\section{XLIV.}

53 Hen. III. m. 6.-Pro Reinerio Abbatis et Hugone Mace.-Rex, etc. Liberate de thesauro nostro statim Reynerio Abbatis et Hugoni Mace et sociis suis, mercatoribus Florentinis, ducentas libras, in quibus eis tenemur pro ducentis libris quas nobis mutuo tradiderunt ad pannos et alia garderobæ nostræ necessaria, a quibusdam aliis mercatoribus transmarinis ad opus nostrum capta per Ricardum de Ewell et Johannem de Sotton, emptores garderobæ nostræ, in nundinis S. Ivonis, anno etc. liij, inde acquietanda, et quas magister Johannes de Chyshull, cancellarius noster, magister Thomas de Wymundeham, thesaurarius noster, et Petrus de Wintonia, custos garderobæ nostræ, manuceperunt solvere pro nobis mercatoribus antedictis; prout in litteris eorumdem Johannis, Thomæ et Petri, obligatoriis, quas iidem mercatores inde habent, plenius continetur. Proviso quod, soluta eisdem mercatoribus pecunia prædicta, recipiatis ab eis litteras prædictorum Johannis, Thomæ et Petri, prædictas, quas inde habent. T. R. apud Windesoram, xx die Maii.

\section{XLV.}

53 Hen. III. m. 3.-Pro Reinerio Abbatis et sociis suis.-Rex, etc. Liberate de thesauro nostro Reynerio Abbatis et sociis suis, Hugonetto Simonetti et sociis suis, Bernardo Arloti et sociis suis, civibus et mercatoribus Florentinis, Loto . . . . . et sociis suis, 
Hugelino Bonaventuri et sociis suis, mercatoribus Senensibus, et Jacobo Agelaunt et sociis suis, mercatoribus de Pistoie, trescentas marcas, quas nobis tradiderunt ad quasdem providentias contra instans festum Translationis beati Edwardi inde faciendas. Non omittentes quin eis satisfiat de pecunia prædicta citra festum beati Hillarii proximum sequens. Et, facta solutione prædictæ pecuniæ, recipiatis ab eisdem mercatoribus litteras nostras patentes, quas habent, dictam pecuniam testificantes. T. me ipso, apud Wintoniam, xx die Augusti.

\section{XLVI.}

55 Hen. III. m. 4.-Rex baronibus suis de scaccario, salutem. Allocate venerabili patri W. Eboracensi archiepiscopo, cui commisimus comitatus nostros Notinghamiæ et Derbiæ, in exitibus eorundem comitatuum, quadraginta libras, de illis centum libris de quibus fecit profrum suum ad crastinum Paschæ proximo præteritum; quas quidem quadraginta libras idem archiepiscopus liberavit per præceptum nostrum Dentayto, mercatori nostro et carissimæ consortis nostræ Alienoræ Reginæ Anglice, pro quadraginta libris quas idem Dentaytus liberavit fisicis nostris, pro expensis suis quas fecerunt in servitio nostro, tempore quo nuper detenti fuimus gravi infirmitate apud Westmonasterium; a qua convaluimus, benedictus Deus! T. R. apud Westm. xiij die Junii.

\section{XLVI.}

56 Hen. III. m. 11.-Rex, etc. Liberate de thesauro nostro Poncio de Mora, mercatori nostro, cc marcas quas ei concessimus de dono nostro, in recompensationem dampnorum quæ idem Poncius, per mutuum pecuniæ suæ nobis pluries factum, sustinuit. T. R. apud Westm. xxvj die Februarii.

\section{XLVII.}

56 Hen. III. m. 7.-Rex, etc. Allocate venerabili patri W. Eboracensi archiepiscopo, Angliæ primati, vicecomiti nostro Notinghamiæ et Derbiæ, in exitibus vel frma sua eorundem comitatuum, quaterviginti et septem libras, sex solidos et octo denarios, quos per præceptum nostrum liberavit Dentaeto, mercatori karissimæ consortis nostræ; videlicet, quinquaginta et quinque marcas pro quinquaginta et quinque marcis quas idem Dentaetus, per præceptum nostrum, liberavit Elia capellano Edmundi filii nostri, pro remissione feodi sui quod de nobis percipere consuevit; et viginti et sex marcas . . . . . ..... marcis quas idem Dentaetus per præceptum nostrum liberavit karissimæ consorti nostræ Alyanoræ Reginæ Angliæ, tempore quo ipsa ultimo fuit apud Dovoriam, ad munitionem ejusdem castri ; et quinquaginta marcas pro quinquaginta marcis quas idem Dentaetus liberavit pueris de Sabaundia, nepotibus nostris, de termino Paschæ 
proximo præterito, de annuo feodo suo centum marcarum ..... percipiunt per annum ad scaccarium nostrum, ad sustentationem suam. T. R. apud Westm. xxv die Maii.

\section{XLVIII.}

1 Edw. I.-Pro Luka de Luka et sociis suis.-Rex etc. Liberate de thesauro nostro Lucæ de Luka et sociis suis, mercatoribus de Luka, mille libras, in partem solutionis debitorum in quibus eis tenemur de præstito nobis facto in partibus transmarinis. Dat. per manum W. de Mertonia, cancellarii nostri, apud Westm. xxiij die Octobris.

\section{XLIX.}

1 Edw. I.-Pro Luka de Luka.-Rex etc. Liberate de thesauro nostro Lucæ de Luka, mercatori, mille marcas, in partem satisfactionis pecuniæ quam idem Lucas et socii sui, mercatores, nuper mutuo liberaverunt fratri Josep Hospitalario in nundinis de Provynz, ad negotia nostra ibidem expedienda. Dat. per manum W. de Mertonia, cancellarii nostri, apud Westm. vj. die Julii.

\section{XLIX}

1 Edw. I.-Pro Luka de Luka.-Rex etc. Liberate de thesauro nostro Lucæ de Luka, mercatori de Luka, mille marcas, solvendas Philippo de Bernancini, civi Januensi, quas eidem Philippo solvi mandavimus per litteras nostras patentes, in solutionem cujusdam debiti in quo ei tenebamur; quas quidem litteras dictus Philippus præfato Lucæ liberabit, nobis in adventu nostro restituendas. Dat. ut supra, xxviij die Aprilis.

L.

I Edw. I.-Pro Luka de Luka.-Rex etc. Liberate de thesauro nostro Lucæ de Luka, mercatori de Luka, mille libras, in partem solutionis debitorum in quibus ei tenemur. Dat. ut supra, xviij die Aprilis.

LI.

2 Edw. 1.-Pro Aldebrando, mercatore de Luka, et sociis suis.-Rex etc. Liberate de thesauro nostro, in festo Paschæ proximo futuro, Aldebrandino mercatori de Luka, et sociis suis, ducentas libras, pro illis ducentis libris quas mutuarunt karissimo avunculo nostro Guydoni de Leziniaco, et in quibus dominus H. Rex, pater noster, eidem Gui-doni tenebatur, de residuo finis mille marcarum quem idem pater noster fecit cum ipso pro remissione feodi quingentarum marcarum, quod percipere consuevit per annum ad scaccarium dicti patris nostri, et etiam pro remissione arreragiorum feodi supradicti. 
Et, facta eis liberatione prædicta, recipiatis ab eis litteras nostras patentes, quas habent, pecuniam illam testificantes. T. R. apud Windesoram, xx die Septembris.

Vacat, quia restitutum fuit breve et non habuit illud.

LII.

2 Edw. I.-Pro Luca de Lnka et sociis suis.-Rex, etc. Liberate de thesauro nostro Lucæ de Luka et sociis suis, mercatoribus Florentinis, tria millia et quingentas marcas, in partem solutiones debitorum in quibus eis tenemur de mutuo quod nobis fecerunt ad ardua negotia nostra inde expedienda. Proviso quod tantum nobis decidat de debitis supradictis. T. R. apud Turrim Londinensem, ix die Octobris.

LIII.

2 Edw. I.-Pro Luca de Luka.-Rex, etc. Liberate de thesauro nostro Lucæ de Luka, mercatori, sexaginta et decem marcas, pro illis sexaginta et decem marcis quas per præceptum nostrum solvit Nuco de Florentia, mercatori, pro quodam equo ab eodem Nuco ad opus nostrum empto, quem dilecto et fideli nostro Roberto de Typetot dedimus. T. R. apud Westm. xv. die Octobris.

LIV.

2 Edw. I.-Pro Bonasio Bonancy--Rex, etc. Liberate de thesauro nostro dilecto mercatori nostro Bonasio Bonanci quinquaginta marcas, in partem solutionis debiti in quo tenemur eidem. T. R. apud Westm. xvij die Octobris.

LV.

2 Edw. I.-Pro Tegro Amatons.-Rex, etc. Liberate de thesauro nostro Tegro Amatons et sociis suis, mercatoribus de Florentia, septingentas marcas, in partem solutionis debitorum in quibus eis tenemur de mutuo quod nobis fecerunt in curia Romana, in reditu nostro a Terra Sancta. Proviso tamen quod tantum nobis decidat de debitis supradictis. T. ut supra.

LVI.

2 Edw. I.-Pro Luca de Luka.-Rex, etc. Liberate de thesauro nostro Lucæ de Luka, mercatori de Florentia, quaterviginti libras, pro quaterviginti libris quas per præceptum nostrum liberaverunt dilecto et fideli nostro Mauritio de Crohun, pro quadraginta libris annuis de anno regni nostri primo, quas percipit per annum pro manerio de Bourne [?] quod karissima mater nostra Alianora Regina Angliæ tenet ad vitam suam. T. R. apud Westm. xxv die Octobris. 
LVII.

2 Edw. I.-Pro Luca de Luka.-Rex, etc. Liberate de thesauro nostro Lucæ de Lukes, mercatori nostro, quadringentas libras ; videlicet, trescentas libras pro trescentis libris quas idem Lucas liberavit probis hominibus nostris Lemovicensibus, pro quodam mutuo quod nobis fecerunt, et unde litteras nostras patentes penes se habent, quas per manus ejusdem Lucæ in garderoba nostra liberabunt; et centum libras pro centum libris quas liberavit per præceptum nostrum dilecto consanguineo nostro Amadeo de Sabaudia, de dono nostro. T. ut supra.

\section{LVIII.}

3 Edw. I. m. 12,-De expensis Regis acquietandis.-Rex, etc. Liberate de thesauro nostro magistro Thomæ Bek, custodi garderobæ nostræ, quingentas marcas, ad expensas hospitii nostri inde acquietandas. Proviso quod solutio pecuniæ illius fiat Lucæ de Luka, mercatori nostro, præfato Thomæ defendere, sicut ei plenius est injunctum. T. R. apud Geytingtoniam, $\mathrm{x}$ die Decembris.

LIX.

3 Edw. I. m. 12.-Rex, etc. Allocate prædictis Johanni et Galfrido, nuper custodibus Regis episcopatus Dunelmensis, in exitibus ejusdem episcopatus, quadringentas quinquaginta et tres libras, tresdecim solidos et quatuor denarios, quos per præceptum nostrum liberaverunt Donasio Bonancy, pro mutuo tantæ pecuniæ quod nobis nuper fecerat ad negotia nostra inde expedienda. Allocate etiam eisdem Johanni et Galfrido, in exitibus prædictis, quingentas et quadraginta et sex libras, tresdecim solidos et quatuor denarios, quos per præceptum nostrum liberaverunt Odoni de Gaske, mercatori, pro mutuo tantæ pecuniæ; et quadringentas et sexaginta et sex libras, tresdecim solidos et quatuor denarios, quos per præceptum nostrum liberaverunt Tegro Amacy, mercatori, pro mutuo tantæ pecuniæ ad negotia nostra inde expedienda. . . . . .

LX.

3 Edw. I. m. 12.-Pro Bonamco de Florentia.-Rex, etc. Liberate de thesauro nostro Bonamco de Florentia centum marcas, pro expensis suis et sociorum suorum quas fecerunt in servitio nostro, de dono nostro. T. R. apud Marlebergh, vij die Januarii.

LXI.

3 Edw. I. m. 9.-Pro Luca de Luka.-Rex, etc. Liberate de thesauro nostro Lucæ de Luca, mercatori nostro, duo milia librarum, in partem solutionis debitorum in quibus ei tenemur. Et hoc nullatenus omittatis. T. R. apud Westm. xxvj die Aprilis. 


\section{LXII.}

3 Edw. I. m. 9.-Pro Peroche de Placentia et sociis suis.-Rex, etc. Liberate de thesauro nostro Peroche de Plasentia et sociis suis, mercatoribus domini Papæ, quingentas marcas, pro illis quingentis marcis quas ad rogatum nostrum tradiderunt ex mutuo dilecto clerico nostro magistro Thomæ Bek, custodi garderobæ nostræ, ad expensas hospitii nostri. T. R. apud Westm. xxx die Aprilis.

\section{LXIII.}

3 Edw. I. m. 5.-Pro Denceoto Guilelmy.-Rex, etc. Liberate de thesauro nostro dilecto mercatori nostro Denceoto Guillelmi quadringentas et quadraginta et duas libras, decem et octo solidos et decem denarios ; videlicet, pro quadringentis marcis quas idem Denceotus, per præceptum tenentium locum nostrum in Anglia, liberavit karissimæ matri nostræ̣ Alianoræ Reginæ Angliæ ad expensas suas, tempore quo fuit indotata, et pro ducentis sexaginta et quatuor marcis quinque solidis et sex denariis residuis, tam pro dampnis galiottorum quam pro diversis liberationibus per ipsum Dencettum de præcepto tenentium locum nostrum factis in diversis locis, et etiam pro diversis dampnis et jacturis quæ idem Dencettus sustinuit tempore quo habuit de nobis ad firmam novum auxilium: quam quidem pecuniam recepisse debuerat de eodem novo auxilio in anno sequenti, et quam non recepit pro eo quod idem novum auxilium traditum fuit Lucæ de Luka custodiendum. T. R. apud Westm. xxij die Junii.

\section{LXIV.}

3 Edw. I. m. 2.-Pro Luca de Luka et sociis suis.-Rex, etc. Liberate de thesauro nostro dilecto mercatori nostro Lucæ de Luka et sociis suis, mercatoribus de Luka, quadringentas libras, pro quadringentis libris quas pro nobis liberaverunt nobili viro Eschinato comiti Bygorriæ, in perpacationem duorum milium marcarum in quibus dominus H. Rex pater noster sibi per litteras suas patentes tenebatur pro remissione feodi, et arreragiorum, quod idem comes ad scaccarium ejusdem patris nostri percipere consuevit; nisi pecuniam illam prius habuerit per aliud breve nostrum. Et, facta eis liberatione illa, recipiatis ab eis litteras illas patentes, quas penes se habent, dictam pecuniam testificantes. T. R. apud Westm. xv die Octobris.

\section{LXV.}

3 Edw. I. m. 3.-Pro Luca de Luka.-Rex, etc. Liberate de thesauro nostro Lucæ de Luka et sociis suis, mercatoribus de Luka, tria milia sexaginta et sex libras, tresdedecim solidos et iij denarios, in partem solutionis debitorum in quibus eis tenemur. $\mathbf{T}$. R. apud Westm. xxviij die Octobris. 


\section{I.XVI.}

3 Edw. I. m. 1.-Pro Hugelino de Emthio et Lotero Bonawyde.-Rex, etc. Liberate de thesauro nostro, in festo Purificationis beatæ Mariæ proximo futuro, Hugelino de Emthio et Lotero Bonawyde et sociis suis, mercatoribus de Florentia, quingentas marcas, in perpacationem omnium debitorum in quibus eis tenemur per quinque paria litterarum patentium sigillo domini $\mathbf{H}$. Regis, patris nostri, et nostro signatarum. Et, facta eis liberatione illa, recipiatis ab eis prædicta quinque paria litterarum patentium, necnon et litteras patentes, sigillis suis signatas, de remissione et quieta clamantia omnium debitorum in prædictis litteris nostris contentorum. T. R. apud Westm. xiiij die Junii.

\section{LXVII.}

4 Edw. I. m. 11.-Pro Theobaldo Malagalye et sociis suis.-Rex, etc. Liberate de thesauro nostro Theobaldo Malagalye et sociis suis, mercatoribus de Luca, mille ducentas et decem marcas, pro mille ducentis et decem marcis quas nobis nuper Parisiis mutuo tradiderunt, ad quædam ardua negotia nostra inde expedienda. Et, facta eis liberatione illa, recipiatis ab eis litteras suas obligatorias dictam pecuniam testificantes, necnon et litteras suas de quietantia pecuniæ supradictæ. T. R. apud Wyntoniam, $x x$ die Januarii.

\section{LXVIII.}

4 Edw. I. m. 11.-Pro Luca de Luka.-Rex, etc. Allocate Lucasio de Luka et sociis suis, in compoto suo de nova custuma, octo milia librarum, quas per præceptum nostrum liberaverunt in garderoba nostra, die Veneris in Conversione S. Pauli, anno regni nostri quarto, dilecto clerico nostro magistro Thomæ Bek, custodi ejusdem garderobæ. T. R. apud Wyntoniam, xxiij die Januarii.

\section{LXIX.}

4 Edw. I. m. 7.-Rex, etc. Liberate de thesauro nostro Dietainto, mercatori karissimæ matris nostræ Alianoræ Reginæ Angliæ, quadringentas quadraginta et duas libras, decem et octo solidos et decem denarios, in quibus ei tenemur de antiquis et diversis debitis ab ipso mutuo receptis, ad urgentissima negotia nostra inde expedienda. T. R. apud Westm. vij die Junii.

Vacat, quia restitutum fuit et cancellatum, et per Lukam de Luka satisfactum.

\section{LXX.}

4 Edw. I. m. 5.-Rex, etc. Liberate de thesauro nostro dilecto mercatori nostro Nuto de Florentia lxx marcas, quas pro nobis liberavit dilecto et fideli nostro Johanni 
de Bohun, in partem solutionis cujusdam summæ pecuniæ in qua ei tenemur. T. R. apud Westm. xxiij die Julii.

Vacat, quia restitutum fuit et cancellatum, et per Lukam de Luka satisfactum.

\section{LXXI.}

4. Edw. I. m. 3.-Rex baronibus suis de scaccario Dublinensi, salutem. Allocate magistro Thomæ de Cheddeworth, custodi nostro archiepiscopatus Dublinensis, vacantis et in manu nostra existentis, trescentas et sex libras, tresdecim solidos et quatuor denarios, quos per præceptum nostrum liberavit Percevallo de Luka et sociis suis, mercatoribus de Luka, ad quædam negotia nostra inde expedienda; et quingentas quadraginta et unam libras, septem solidos et octo denarios, quos similiter per proceptum nostrum liberavit Lucæ de Luka et sociis suis, mercatoribus de Luka, ad negotia nostra inde expedienda; quæ solutio eisdem mercatoribus facta fuit per tres vices. T. R. apud Bristolliam, xxij die Septembris.

\section{LXXII.}

5 Edw. I. m. 6.-De negotiis Regis expediendis.-Rex thesaurario et camerariis suis de scaccario, salutem. Liberate de thesauro nostro Orlandino de Podio et sociis suis, mercatoribus de Luka, duo milia et $\mathbf{D}$ libras, ad quædam negotia nostra inde expedienda. T. R. apud Westm. xxvj die Aprilis.

\section{LXXIII.}

5 Edw. I. m. 3.-Pro Orlandino de Podio et sociis suis.-Rex, etc. Liberate de thesauro nostro Orlandino de Podio et sociis suis, mercatoribus de Luka, duo milia librarum, ad quædam negotia nostra quæ eis injunximus inde expedienda. T. R. apud Wyndesoram, xxix die Maii.

\section{LXXIV.}

6 Edw. I. m. 2.-De denariis liberandis ad negotia Regis expedienda.-Rex, etc. Liberate de thesauro nostro Orlandino de Podio et sociis suis, mercatoribus nostris de Luka, quatuor milia librarum, ad quædam negotia nostra per præceptum nostrum inde expedienda. T. R. apud Westm. xviij die Maii.

\section{LXXV.}

Per billam de garderoba.

6 Edw. I. m. 1.-De denariis liberandis ad negotia Regis expedienda.-Rex, etc. Liberate de thesauro nostro Orlandino de Podio et sociis suis, mercatoribus de Luka, duo milia librarum, ad negotia nostra quæ sibi injunximus inde expedienda. T. R. apud Westm. xxvj die Junii.

Per magistrum Thomam Beh, thesaurarium garderobe, per billam. 


\section{LXXVI.}

6 Edw. I. m. 1.-De denariis liberandis ad negotia Regis expedienda.-Rex, etc. Liberate de thesauro nostro Orlandino de Podio, Renerio Magiar', et sociis suis, mercatoribus de Luka, duo milia et quingentas marcas, ad quædam negotia nostra quæ eis injunximus inde expedienda. T. R. apud Westm. xxvij die Octobris.

Per billam de garderoba.

\section{LXXVII.}

6 Edw. I. m. 1.-De denarïs liberandis ad negotia Regis expedienda.-Rex, etc. Liberate de thesauro nostro Orlandino de Podio et sociis suis, mercatoribus de Luka, mille et quingentas libras, ad quædam negotia nostra quæ eis injunximus inde expedienda. T. R. apud Westm. $x$ die Novembris.

\section{LXXVIII.}

Per billam de garderoba.

7 Edw. I. m. 7.-De denariis liberandis ad negotia Regis expedienda.-Rex, etc. Liberate de thesauro nostro Reynero de Luka et sociis suis, mercatoribus de Luka, mille libras, ad quædam negotia nostra quæ eis injunximus inde expedienda. T. R. apud Burgh, v die Decembris, anno regni nostri vij.

\section{LXXIX.}

Per billam de garderoba.

(In cedula.) 7 Edw. I.-Rex, etc. Liberate de thesauro nostro Reinerio de Luka et sociis suis, mercatoribus de Luka, septingentas quinquaginta et octo libras, tres solidos et octo denarios, de exitibus tallagii super communitatem Judæorum nostrorum Angliæ ultimo assessi, ad quædam, etc. ut suprc. T. R. apud Wodestoke, v die Februarii, anno regni nostri septimo.

\section{LXXX.}

(In cedula.) 7 Edw. I.-Edwardus, Dei gratia, etc. Liberate de thesauro nostro Reynero de Luka et Orlandino de Podio et sociis suis, mercatoribus de Luka, tria milia marcarum, de exitibus tallagii super communitatem Judæorum, etc. ut supra. Nisi pecuniam illam eisdem prius liberaveritis, per aliud breve nostrum. T. me ipso, apud Wodestoke, v die Februarii, anno regni nostri septimo.

Per Antonium Bek.

(In dorso.) "Pro Reynerio de Luka, Orlandino de Podio et sociis suis, mercatoribus de Luka, de exitibus tallagii ммм marcarum assessi super communitatem Judæorum Angliæ.

“Summa ммм marcæ.

VOL. XXVIII. 
"De quibus soluti sunt eisdem Dcclviij libræ, iij solidi, viij denarii, liberati prædicto Orlandino. Per istud breve restant solvendi mccxlj libræ, xvj solidi, iiij denarii."

\section{LXXXII.}

(In cedula.) 7 Edw. I. m. 1. "Solutæ sunt Reynerio de Luka et sociis suis, mercatoribus de Luka, in scaccario de recepta per thesaurarium et camerarios, мм libræ, super breve suum continens ммм libras.

"Et sic restant solvendæ eisdem mercatoribus per prædictum breve mille libræ.

"Item soluti sunt eisdem Reynero et sociis suis, mercatoribus de Luka, per unum aliud breve de liberate continens ммм marcas, de quodam tallagio assesso super communitatem Judæorum Angliæ, Dcclviij libræ, iij solidi, viij denarii.

“ Et sic restant solvendi eisdem mercatoribus, per prædictum breve, Mxlj libræ, xvj solidi, iiij denarii."

\section{LXXXIII.}

8 Edw. I. m. 4.-Pro Reynero Magiar', mercatore de Luka, et Egidio de Audenarde.Rex, etc. Allocate Reynero Magiar', mercatori de Luka, et Egidio de Audenarde, receptoribus quintædecimæ nostræ, in compoto suo ejusdem quintædecimæ ad scaccarium nostrum, trescentas marcas, quas per visum dilecti clerici nostri Antonii Bek liberaverunt Johanni de Jolins et sociis suis, mercatoribus de Caurce; et quadringentas marcas, quas similiter liberaverunt Peregrino de Luka et Willielmo de Chiatre, mercatoribus de Luka; et centum quinquaginta marcas, quas liberaverunt Petro de Luka et Reynerio Petri et Arigho Symach, mercatoribus de Luka; et mille et ducentas marcas, quas liberaverunt Maynetto Bek et sociis suis, mercatoribus Florentinis; et duo milia marcarum, quas liberaverunt Hugholino de Vichio et Lotherio Bonagide et sociis suis, mercatoribus Florentinis, de societate Teglar' de Scala; et mille marcas, quas liberaverunt Jacobo Agolanci et Ladiassen' Forecii et sociis suis, mercatoribus de Pistoria; et quingentas marcas, quas liberaverunt Jacobo Cap de Maillie et sociis suis, mercatoribus de Monte Pessullano; et mille marcas, quas liberaverunt Bonvicino Nicholai et Duracio, mercatoribus Florentinis ; et mille marcas, quas liberaverunt Bartholomeo Mark et sociis suis, mercatoribus de Sene; et tria milia marcarum, quas liberaverunt Frederico de Kuneo et Reginaldo Monachato et sociis suis, mercatoribus de Florentia; et quinque milia marcarum, quas liberaverunt Reynero Josep et sociis suis, mercatoribus Florentinis, de societate Frescobaldi, Bernardo Manfredi et sociis suis, de societate Chirculorum, Bartholomeo Jacobi et sociis suis, de societate Bardi, Rogero Sampe et sociis suis, de societate Falconeri, mercatoribus Florentinis ; et mille marcas, quas liberaverunt Ubaldo de Luka et Chebaldo et sociis suis, mercatoribus de Luka; et quadringentas marcas, quas liberaverunt Johanni Donaden et 
sociis suis, mercatoribus de Cauz; et trescentas marcas, quas liberaverunt Alphonso Maurini et sociis suis, mercatoribus de Caurc'; pro mutuis nobis per mercatores prædictos factis, ad quædam ardua negotia nostra inde expedienda; prout per litteras nostras patentes, quas eisdem mercatoribus inde fieri fecimus, et quas iidem Reynerus et Egidius inde habent, vobis plenius constare poterit: nisi prius inde allocationem habuerint in toto vel in parte. Et, antequam allocationem illam eisdem Reinerio et Egidio feceritis, recipiatis ab eis litteras nostras prædictas, necnon et litteras prædictorum mercatorum patentes receptionem pecuniæ prædictæ testificantes. T. ut supra.

\section{LXXXIV.}

8 Edw. I. m. 2.-Pro mercatoribus de Luka.-Rex, etc. Liberate de thesauro nostro Orlandino de Podyo et sociis suis, mercatoribus de Luca, trescentas marcas, pro trescentis marcis in quibus dilectus et fidelis noster Johannes Giffard eisdem mercatoribus tenebatur, et quas liberari eis volumus pro prædictó Johanne, in acquietationem prædictarum trescentarum marcarum, de dono nostro. T. R. apud Westm. $x$ die Novembris.

\section{LXXXV.}

9 Edw. I. m. 8.-Pro Bouruncino Walteri et sociis suis, mercatoribus de Luka.-Rex, etc. Liberate de thesauro nostro Baruncino Walteri et sociis suis, mercatoribus de Luka, ducentas quinquaginta et octo marcas, sex solidos et octo denarios, quos, per præceptum nostrum, liberaverunt Johanni Simonetti et sociis suis, civibus et mercatoribus Lucanis, pro ducentis quinquaginta et octo marcis, sex solidis et octo denariis, quos W. Norwicensis episcopus eisdem civibus et mercatoribus per manus dicti Baruncini et sociorum suorum prædictorum solvisse debuerat in festo Purificationis beatæ Mariæ proximo preterito, et quos idem episcopus liberavit in garderoba nostra, ad rogatum nostrum, dilectis clericis nostris.Thomæ de Ganneys et magistro Willielmo de Luda, ad quædam urgentissima negotia nostra inde expedienda. T. R. apud Coleford, viij die Februarii.

\section{LXXXVI.}

9 Edw. I. m.8.-Pro Bouruncino Walteri et sociis suis, mercatoribus de Luka.-Rex, etc. Liberate de thesauro nostro Bouruncino Walteri, Ricardo Guidiccionis, et sociis suis, mercatoribus de Luka, ducentas libras, pro ducentis libris quas iidem mercatores per præceptum nostrum liberaverunt pro nobis dilecto et fideli nostro Johanni de Cameys, in partem solutionis quadringentarum librarum, in quibus eidem Johanni tenebamur pro maneriis suis de Torpel et Upton. Et, cum pecuniam illam præfatis mercatoribus liberaveritis, recipiatis ab eis litteras nostras patentes, quas iidem mercatores inde habent, dictam pecuniam testificantes. T. ut supra. 


\section{LXXXVII.}

10 Edw. I. m. 4.--Pro Bouruncino et sociis suis, mercatoribus de Luka.-Rex, etc. Liberate de thesauro nostro Bouruncino et sociis suis, mercatoribus de Luka, ducentas et quinquaginta libras, pro mille libris Turonensium, quas iidem mercatores liberabunt Thomæ de Sabaudiæ, et quas eidem Thomæ concessimus de dono nostro. T. R. apud Cyrencestriam, xxiiij die Januarii.

\section{LXXXVIII.}

13 Edw. I. m. 8.--Pro Baruncino Galter, mercatore de Luka.-Rex, etc. Liberate de thesauro nostro Baruncino Gualteri, mercatori nostro de Luka, mille libras, pro mille libris in quibus Alianora quondam Comitissa Leycestriæ, amita nostra, quam dudum admisimus ad gratiam et pacem nostram, tenebatur dicto Baruncino, de mutuo eidem Alianoræ et Simoni filio suo per ipsum Baruncinum facto; unde executores testamenti ipsius Alianoræ attornarunt ipsum Baruncinum ad recipiendam pecuniam illam de pecunia eidem Alianoræ debita, tam de exitibus terrarum et tenementorum quæ ipsa tenuit in dotem in Anglia, quam de illis quadringentis libris annuis provenientibus de dote sua in Hibernia, de quibus hæredes Comitis Marescalli, versus quos dominus H. Rex pater noster plegius fuit, et alii qui dotem suam in Anglia tenuerunt in vita sua, eundem patrem nostrum et nos acquietare tenentur. Proviso quod tam illi qui tenuerunt dotem ejusdem Comitissæ in Anglia in vita sua, occasione turbationis habitæ in regno, quam hæredes prædicti Comitis, inde onerentur, et nobis per eosdem satisfiat de mille libris supradictis. Et, facta eidem Baruncino solutione pecuniæ prædictæ, recipiatis ab eodem litteras prædictorum executorum dictam assignationem, necnon et litteras ipsius Baruncini receptionem ejusdem pecuniæ, juxta assignationem prædictam, testificantes. T. R. apud Westm. primo die Julii.

\section{LXXXIX.}

17 Edw. I. m.4.-Pro Ricardo Gwidicionis et sociis suis, mercatoribus de Luka.-Rex, etc. Liberate de thesauro nostro dilecto nostro Ricardo Guidicionis et sociis suis, mercatoribus nostris de Luka, quinque milia marcarum, pro quinque milibus marcarum quas iidem mercatores nostri mutuo receperunt a Rostero Bonaventuro et sociis suis, mercatoribus de societate Mozorum de Florentia, Jacobo Brabazon et sociis suis, mercatoribus de societate de Sena, Bartholomeo Jacobi et sociis suis, mercatoribus de societate Bardorum de Florentia, Jacobo Bonichi et sociis suis, mercatoribus de societate Amanatorum de Pistoria, Bertone Mathi et sociis suis, mercatoribus de societate Circulorum Nigrorum, Dardano Consilii et sociis suis, mercatoribus de societate Circulorum Alborum de Florentia, Hugelino Petri et sociis suis, mercatoribus de societate 
filiorum Beccori de Luka, Jacobo Janiani et sociis suis, mercatoribus de societate Friskebaldorum de Florentia, Guidoni Daunaci et sociis suis, mercatoribus de societate Friskobaldorum de Florentia, et Duracio Huberti et sociis suis, mercatoribus de societate Pulicum de Florentia; ad quædam ardua negotia nostra inde facienda. Ita quod liberatio illa fiat a crastino Clausi Paschæ proximo futuro citra vigiliam Pentecostes proximo sequentem. Et, facta eis liberatione illa, recipiatis ab eis litteras nostras patentes per quas eis tenemur in pecunia supradicta. T. Edmundo comite Cornubiæ, consanguineo Regis, apud Westm. vij die Decembris.

XC.

18 Edw. I. m. 2.-Pro Ricardo Guidicionis et sociis suis, mercatoribus de Luka.-Rex, etc. Liberate de thesauro nostro Ricardo Guidicionis et Ricardo Bonefacii et sociis suis, mercatoribus nostris de Luka, quingentas marcas, pro quingentis marcis quas iidem mercatores per præceptum nostrum liberaverunt Alfonso filio domini Ferandi, quondam filii Regis Hispaniæ, de dono nostro. T. R. apud Westm. xvj die Julii.

\section{XCI.}

18 Edw. 1. m. 2.-Rex, etc. Liberate de thesauro nostro Lapo de Pistoria et sociis suis, mercatoribus de Pistoria, ducentas marcas, pro ducentis marcis quas idem Lapus et socii sui solverunt pro nobis domino Francisco Accursi, legum professori, pro arreragiis annui feodi sui quadraginta marcarum, etc. Et recipiatis ab eisdem mercatoribus litteras nostras patentes quas inde habent, necnon et litteras patentes prædicti Francisci solutionem prædictarum ducentarum marcarum testificantes; quas in thesauraria nostra custodiri faciatis. T. R. apud Kinges Clipstone, xiiij die Octobris.

\section{XCII.}

18 Edw. I. m. 2.-Pro Lapo Bonchi et Grado Pini et sociis suis, mercatoribus.-Rex, etc. Liberate de thesauro nostro Lapo Bonchi et Grado Pini et sociis suis, mercatoribus de societate Amanatorum de Pistoria, tria milia marcarum, pro tribus milibus marcarum quas nobis nuper mutuo tradiderunt per manus dilecti et fidelis nostri Ottonis de Grandisono, cui pecuniam illam dedimus in subsidium transfretationis suæ ad partes Jerosolimitanas. Et, facta eis liberatione illa, recipiatis ab eis litteras nostras patentes quas inde habent, necnon et litteras suas patentes receptionem pecuniæ prædictæ testificantes. T. ut supra.

\section{XCIII.}

19 Edw. I. m. 4.-Rex, etc. Liberate de thesauro nostro dilectis mercatoribus nostris Ricardo Guidicionis, Ricardino Bonefacii, et sociis suis, mercatoribus Lucanensibus, de 
societate Ricardorum de Luca, decem milia librarum, in partem solutionis debiti in quo tenemur eisdem. T. ut supra.

\section{XCIV.}

20 Edw. I. m. 4.-Pro Laurentio de Ludelawe.-Rex, etc. Liberate de thesauro nostro Laurentio de Lodelawe mille marcas, pro mille marcis quas idem Laurentius ad instantiam nostram liberavit Ricardo Guydicionis et sociis suis, mercatoribus nostris de societate Ricardorum de Luca, in partem solutionis cujusdam debiti in quo eisdem mercatoribus tenemur, et unde iidem mercatores litteras nostras patentes habent. Et, facta ei liberatione illa, recipiatis ab eisdem mercatoribus litteras nostras prædictas. T. R. apud Stebenhethe, xj die Decembris.

\section{$\mathrm{XCV}$.}

24 Edw. I. m. 6.-Rex, etc. Liberate de thesauro nostro Orlandino de Podio et sociis suis, mercatoribus de societate Ricardorum de Luca, trescentas libras et viginti et tres denarios, pro sexaginta et duodecim saceis lanæ ab ipsis mercatoribus et priore S. Swithini Wyntoniæ per ipsos mercatores ad opus nostrum emptis. Ita quod iidem mercatores de lanis prædictis nobis respondeant, ut debebunt. T. R. apud Shuldham, $\mathrm{x}$ die Februarii.

[The twelve ensuing numbers (XCVI-CVII) are the entire contents of a roll, singular in its kind, preserved in the Tower Record Office, and bearing the following title : "Litteræ patentes de obligationibus factis per Regem Edwardum diversis mercatoribus super quibusdam pecuniarum summis ab ipsis mutuo receptis, anno regni ejusdem Regis Edwardi primi vicesimo sexto." They may be considered out of place among an uniform series of documents of a different character; but I trust that their interest will excuse their insertion.]

\section{XCVI.}

26 Edw. I.-Rex omnibus ad quos præsentes litteræ pervenerint, salutem. Cum nos, pro urgentissimis negotiis nostris et pro utilitate et defensione regni nostri, teneamur mercatoribus subscriptis in viginti et octo milibus nongentis sexaginta et sex libris et una marca sterlingorum; videlicet, Guydoni Bardi et sociis suis, mercatoribus de societate Spinorum de Florentia, in tribus milibus nongentis et quinque libris sterlingorum; Meliori Pistoresi et sociis suis, mercatoribus de societate Amanatorum de Pistoria, in mille nongentis quaterviginti et tresdecim libris et dimidia marca sterlingorum; et Villano Stoldi et sociis suis, mercatoribus de societate Circulorum Nigrorum, in tribus milibus octingentis decem et septem libris sterlingorum; et Burdo Squarchie et sociis 
suis, mercatoribus de societate Circulorum Alborum, in tribus milibus ducentis quaterviginti et duodecim libris sterlingorum; et Thadeo Orlandi et sociis suis, sociis de societate Bardorum de Florentia, in septingentis triginta et sex libris sterlingorum; et Raynerio Belyntheni et sociis suis, mercatoribus de societate Pullicum et Rimbertinorum, in duobus milibus quingentis viginti et tribus libris et dimidia marca sterlingorum; et Philippo Bourgy et sociis suis, mercatoribus de societate Mozorum, in tribus milibus septingentis quadraginta et quatuor libris sterlingorum; et Taldo Janiani et sociis suis, mercatoribus de societate Friscobaldorum Alborum, in quatuor milibus sexcentis sexaginta et sex libris et una marca sterlingorum; et Johanni Recemonti et sociis suis, mercatoribus de societate Friscobaldorum Nigrorum, in mille quaterviginti et novem libris et dimidia marca sterlingorum; et Colenchio Ballardi et sociis suis, mercatoribus de Luca, in quingentis triginta et tribus libris et dimidia marca sterlingorum; et Jacobo Brabazoun et sociis suis, mercatoribus de societate de Senis, in sexcentis sexaginta et sex libris et una marca sterlingorum; solvendis eisdem mercatoribus cum ab eisdem vel sociis suis fuerimus requisiti : ita, tamen, quod tota summa pecuniæ quam prædicti mercatores et socii sui societatum prædictarum receperunt, per præceptum nostrum, de custodibus custumæ lanarum et coriorum in diversis portubus regni nostri, vel ex aliis quibuscumque, nomine nostro, usque ad sextum diem Maii proximo præteritum, prout per computationem ad scaccarium nostrum inde faciendam constare poterit, decidat et subtrahatur ex prædicta summa totali per mercatores cujuslibet societatis, juxta portionem quamlibet societatem contingentem; prout in litteris nostris patentibus, mercatoribus cujuslibet societatis de summa pecuniæ eis debita confectis, plenius continetur: Volentes prædictis mercatoribus et sociis suis de dictis pecuniarum summis satisfacere quamcitius poterimus, ut tenemur, de assensu et voluntate mercatorum societatum prædictarum, concessimus et assignavimus, pro nobis et hæredibus nostris, eisdem mercatoribus et eorum sociis omnes exitus provenientes de custuma lanarum, pellium lanutarum et coriorum, in portubus Berewici super Twedam, Novi Castri super Tynam, Kingeston super Hull, S. Botulphi, Lenne, Jernemuthæ, Gipewici, Sandwici, Londoniæ, Suthamptoniæ, Bristolliæ; recipiendos per manus custodum nostrorum custumæ prædictæ, et per cirographum inter prædictos custodes et ipsum mercatorem, de omnibus et singulis exitibus provenientibus de custuma prædicta; et custodiam unius partis sigilli nostri quod vocatur Coket, in singulis portubus supradictis; a predicto sexto die Maii quousque eisdem mercatoribus et eorum sociis de summa pecuniæ eis debitæ, ut prædictum est, plenarie fuerit satisfactum in forma prædicta. In cujus rei testimonium has litteras nostras fieri fecimus patentes. T. me ipso, apud Ely, septimo die Maii, anno regni nostri vicesimo sexto. 


\section{XCVII.}

26 Edw. I.-Rex omnibus ad quos præsentes litteræ pervenerint, salutem. Sciatis quod nos, pro illis septingentis quadraginta et quinque libris sterlingorum quas ex mutuo recepimus de Restorio Bonaventuri et sociis suis, mercatoribus de societate Spinorum de Florentia, per manus W. Bathoniensis et Wellensis episcopi, thesaurarii nostri, et camerariorum nostrorum de scaccario, in termino $\mathrm{S}$. Michaelis, anno regni nostri vicesimo secundo finiente, incipiente vicesimo tertio, per duas tallias de eodem scaccario, quas dicti mercatores nobis restituerunt ad scaccarium prædictum, et pro illis trescentis triginta et tribus libris et dimidia marca sterlingorum quas similiter ex mutuo recepimus de eisdem Ristorio et sociis suis per manus Walteri de Langeton, thesaurarii nostri, et camerariorum nostrorum de eodem scaccario, decimo nono die Octobris, anno regni nostri vicesimo tertio, per litteras nostras sub sigillo ejusdem scaccarii patentes, quas iidem mercatores nobis restituerunt ad idem scaccarium; et pro illis mille sexcentis sexaginta et sex libris et una marca sterlingorum, quas similiter ex mutuo recepimus de eisdem Restorio et sociis suis per manus Walteri Coventrensis et Lychefeldensis episcopi, thesaurarii nostri, et camerariorum nostrorum de eodem scaccario, decimo nono die Februarii, anno regni nostri vicesimo quinto, per litteras nostras de eodem sigillo patentes, quas iidem mercatores nobis restituerunt ad dictum scaccarium; et pro illis mille centum et sexaginta libris sterlingorum quas ex mutuo recepturi sumus de Guydone Bardi et sociis suis, mercatoribus de prædicta societate Spinorum, pro portione ipsam societatem Spinorum contingente de illis decem milibus librarum quas dicti Guydo et socii sui, de dicta societate Spinorum, et mercatores aliarum decem societatum, nobis ex mutuo liberabunt, (quibus quidem mercatoribus litteras nostras patentes de portione decem milium librarum prædictarum quamlibet societatem contingente fieri fecimus, prout in rotulo memorandorum ejusdem scaccarii nostri de termino Paschæ, anno regni nostri vicesimo sexto, plenius continetur, ad terminos infrascriptos, videlicet in festo Nativitatis S. Johannis Baptista proximo futuro et octavo die Augusti proximo sequente, per æquales portiones; prout continetur in litteris obligatoriis mercatorum prædictarum undecim societatum nobis de prædictis decem milibus librarum confectis, quæ in custodia dictorum Walteri Coventrensis et Lichefeldensis episcopi, thesaurarii nostri, et camerariorum nostrorum de eodem scaccario, jam existunt:) tenemur prædictis Guydoni Bardi et sociis suis, mercatoribus dictæ societatis Spinorum, in tribus milibus nongentis et quinque libris sterlingorum. De quibus quidem tribus milibus nongentis et quinque libris Guydoni et sociis suis, mercatoribus de dicta societate Spinorum, satisfieri faciemus cum ab eisdem Guydone et sociis suis fuerimus requisiti. Ita, tamen, quod tota summa pecuniæ quam prædicti Guydo et socii" sui, mercatores dictæ societatis Spinorum, receperunt per præceptum nostrum de custodibus custumæ lanarum et 
coriorum in diversis portubus regni nostri, vel ex alis quibuscumque, nomine nostro, usque ad diem confectionis presentium, prout, per computationem ad scaccarium nostrum inde faciendam, constare poterit, decidat et subtrahatur a dicta summa trium milium nongentarum et quinque librarum. In cujus rei testimonium has litteras nostras fieri fecimus patentes. 'T. me ipso, apud Ely, sexto die Maii, anno regni nostri vicesimo sexto.

\section{XCVIII.}

$26 \mathrm{Edw}$. L.- Rex omnibus ad quos præsentes litteræ pervenerint, salutem. Sciatis - quod nos, pro illis quingentis libris sterlingorum quas ex mutuo recepimus de Lapo Bonyth' et sociis suis, mercatoribus de societate Amanatorum de Pistoria, per manus Walteri de Langeton, thesaurarii nostri, et camerariorum nostrorum de scaccario, in termino Paschie anno regni nostri vicesimo tertio, per duas tallias de eodem scaccario, quas dicti mercatores nobis restituerunt, ad scaccarium prædictum ; et pro illis trescentis triginta et tribus libris et dimidia marca, sterlingorum, quas similiter ex mutuo recepimus de eisdem Lapo et sociis suis, per manus eorumdem thesaurarii et camerariorum nostrorum de eodem scaccario, decimo nono die Octobris anno regni nostri vicesimo tertio, per litteras nostras sub sigillo ejusdem scaccarii patentes, quas iidem mercatores nobis restituerunt, ad idem scaccarium; et pro illis mille centum et sexaginta libris sterlingorum quas ex mutuo recepturi sumus de Meliori Pistoresi et sociis suis, mercatoribus de præedicta societate Amanatorum, pro portione ipsam societatem contingente de illis decem milibus librarum quæ dicti Meliori et socii sui, de dicta societate Amanatorum, et mercatores aliarum decem societatum, nobis ex mutuo liberabunt; quibus quidem mercatoribus litteras nostras, etc. ut supra. Teste, ut supra.

\section{XCIX.}

26 Edw. I.-Rex omnibus ad quos præsentes litteræe pervenerint, salutem. Sciatis quod nos, pro illis duobus milibus quadringentis quinquaginta et septem libris sterlingorum quas ex mutuo recepimus de Carochio Huberti et sociis suis, mercatoribus de societate Circulorum Nigrorum, per manus W. Bathoniensis et Wellensis episcopi, thesaurarii nostri, et camerariorum nostrorum de scaccario, in termino S. Michaelis, anno regni nostri vicesimo secundo finiente, incipiente vicesimo tertio, per duas tallias, etc. ut supra; et pro illis ducentis libris sterlingorum quas similiter ex mutuo recepimus de eisdem Carochio et sociis suis, per manus Walteri Coventrensis et Lichfeldensis episcopi, thesaurarii nostri, et camerariorum nostrorum de eodem scaccario, nonodecimo die Februarii, anno vicesimo quinto, per litteras nostras, etc. ut supra; et pro illis mille centum et sexaginta libris sterlingorum quas ex mutuo recepturi sumus de Villano Stoldi et sociis suis, mercatoribus de prodicta societate Circulorum Nigrorum, pro portione ipsam societatem contingente, etc. ut supra. Teste, ut supra.

VOL. XXVIII. 
C.

26 Edw. I. Rex omnibus ad quos præsentes litteræ pervenerint, salutem. Sciatis quod nos, pro illis duobus milibus centum triginta et duabus libris sterlingorum quas ex mutuo recepimus de Dardano Consilii et sociis suis, mercatoribus de societate Circulorum Alborum, per manus Willielmi Bathoniensis et Wellensis episcopi, thesaurarii nostri, et camerariorum nostrorum de scaccario, in termino S. Michaelis, anno regni nostri vicesimo secundo finiente, incipiente vicesimo tertio, per duas tallias, etc. ut supra; et pro illis mille centum et sexaginta libris sterlingorum quas ex mutuo recepturi sumus de Byndo Squarchie et sociis suis, mercatoribus de prædicta societate Circulorum Alborum, pro portione, etc. ut supra. Teste, ut supra.

CI.

26 Edw. I.-Rex omnibus ad quos præsentes litteræ pervenerint, salutem. Sciatis quod nos, pro illis mille et triginta libris sterlingorum quas ex mutuo recepimus de Brachio Gerardi et sociis suis, mercatoribus de societate Pullicum et Rembertinorum de Florentia, per manus Willielmi Bathoniensis et Wellensis episcopi, thesaurarii nostri, et camerariorum nostrorum de scaccario, in termino S. Michaelis anno regni nostri vicesimo secundo finiente, incipiente vicesimo tertio, per duas tallias, etc. ut supra; et pro illis trescentis triginta et tribus libris et dimidia marca, sterlingorum, quas similiter ex mutuo recepimus de eisdem Brachio et sociis suis, per manus Walteri de Langeton, thesaurarii nostri, et camerariorum nostrorum de eodem scaccario, nonodecimo die Octobris anno regni nostri vicesimo tertio, per litteras nostras sub sigillo ejusdem scaccarii patentes, quas iidem mercatores nobis restituerunt ad idem scaccarium; et pro illis mille centum et sexaginta libris sterlingorum quas ex mutuo recepturi sumus de Reynerio Bellinchori et sociis suis, mercatoribus de prædicta societate Pullicum et Rembertinorum, pro portione ipsam societatem contingente, etc. ut supra. Teste, ut supra.

CII.

26 Edw. I.-Rex omnibus ad quos præsentes litteræ pervenerint, salutem. Sciatis quod nos, pro illis mille centum quaterviginti et quatuor libris sterlingorum quas ex mutuo recepimus de $\mathbf{J}$ acobo Ananzat et sociis suis, mercatoribus de societate Mozorum de Florentia, per manus Willielmi Bathoniensis et Wellensis episcopi, thesaurarii nostri, et camerariorum nostrorum de scaccario, in termino $\mathbf{S}$. Michaelis anno regni nostri vicesimo secundo finiente, incipiente vicesimo tertio, per duas tallias, etc. ut supra; et pro illis trescentis triginta et tribus libris et dimidia marca, sterlingorum, quas similiter ex mutuo recepimus de eisdem Jacobo et sociis suis, per manus Walteri de Langeton, thesaurarii nostri, et camerariorum nostrorum de eodem scaccario, decimo 
nono die Octobris anno regni nostri vicesimo tertio, per litteras nostras sub sigillo ejusdem scaccarii, quas iidem mercatores nobis restituerunt, ad idem scaccarium; et pro illis mille sexaginta et sex libris et una marca, sterlingorum, quas similiter ex mutuo recepimus ab eisdem Jacobo et sociis suis, per manus Walteri Coventrensis et Lichfeldensis episcopi, thesaurarii nostri, et camerariorum nostrorum de eodem scaccario, decimo nono die Februarii anno regni nostri vicesimo quinto, per litteras nostras, etc. ut supra; et pro illis mille centum et sexaginta libris sterlingorum quas ex mutuo recepturi sumus de Philippo Burgy et sociis suis, mercatoribus de prædicta societate

- Mozorum, pro portione ipsam societatem Mozorum contingente, etc. ut supra. Teste, ut supra.

\section{CIII.}

26 Edw. I.-Rex omnibus ad quos præsentes litteræ pervenerint, salutem. Sciatis quod nos, pro illis quatuor milibus librarum sterlingorum quæ ex mutuo recepimus de Jacobo Janiani et sociis suis, mercatoribus de societate Friscobaldorum Alborum, per manus Willielni Bathoniensis et Wellensis episcopi, etc. ut supra; et pro illis sexcentis sexaginta et sex libris et una marca sterlingorum quas ex mutuo recepturi sumus de Taldo Janiani et sociis suis, mercatoribus de prædicta societate Friscobaldorum Alborum, pro portione ipsam societatem Friscobaldorum Alborum contingente, etc. ut supra. Teste, ut supra.

\section{CIV.}

$26 \mathrm{Edw}$. I.-Rex omnibus ad quos præsentes litteræ pervenerint, salutem. Sciatis quod nos, pro illis octingentis sexaginta et sexdecim libris sterlingorum quas ex mutuo recepimus de Guidone Danante et sociis suis, mercatoribus de societate Friscobaldorum Nigrorum, per manus Walteri Coventrensis et Lichfeldensis episcopi, thesaurarii nostri, et camerariorum nostrorum de scaccario, decimo nono die Februarii, anno regni nostri vicesimo quinto, per litteras nostras, etc.; et pro illis ducentis et tresdecim libris et dimidia marca sterlingorum quas ex mutuo recepturi sumus de Johanne Recenonti et sociis suis, mercatoribus de prædicta societate Friscobaldorum Nigrorum, pro portione ipsam societatem Friscobaldorum Nigrorum contingente, etc. ut supra. Teste, ut supra.

\section{CV.}

26 Edw. I.-Rex omnibus ad quos præsentes litteræ pervenerint, salutem. Sciatis quod nos, pro illis ducentis libris sterlingorum quas ex mutuo recepimus de Burnetto Bulgarin et Collouchio Ballardi, mercatoribus de Luka, per manus Willielmi Bathoniensis et Wellensis episcopi, thesaurarii nostri, et camerariorum nostrorum de scaccario, in termino S. Michaelis, anno regni nostri vicesimo secundo finiente, incipiente vicesimo tertio, per duas tallias, etc.; et pro illis trescentis triginta et tribus libris et dimidia 
marca sterlingorum quas ex mutuo recepturi sumus de prædicto Collouchio ct sociis suis, mercatoribus de Luka, pro portione ipsam societatem de Luka contingente, etc. ut supra. Teste, ut supra.

\section{CVI.}

$26 \mathrm{Edw}$. I.-Rex omnibus ad quos præsentes litteræ pervenerint, salutem. Sciatis quod nos tenemur Jacobo Brabazan et sociis suis, mercatoribus de societate de Sene, in sexcentis sexaginta et sex libris et una marca sterlingorum, quas ex mutuo recepturi sumus de prædictis Jacobo et sociis suis, mercatoribus de prædicta societate de Sene, pro portione ipsam societatem de Sene contingente, etc. ut supra. Teste, ut supra.

\section{CVII.}

$26 \mathrm{Edw}$. I.-Rex omnibus ad quos præsentes litteræ pervenerint, salutem. Sciatis quod nos, pro illis mille quingentis et sexaginta et sexdecim libris sterlingorum quas ex mutuo recepimus de Thadeo Orlandi et sociis suis, mercatoribus de societate Bardorum de Florentia, per manus Willielmi Bathoniensis et Wellensis episcopi, thesaurarii nostri, et camerariorum nostrorum de scaccario, in termino S. Michaelis, anno regni nostri vicesimo secundo finiente, incipiente vicesimo tertio, per duas tallias, etc.; et pro illis mille centum et sexaginta libris sterlingorum quas ex mutuo recepturi sumus de eisdem Thadeo Orlandi et sociis suis, mercatoribus de prædicta societate Bardorum, pro portione ipsam societatem Bardorum contingente, etc. ut supra. Teste, etc. ut supra.

\section{CVIII.}

27 Edw. I.-Pro Coppo Josep' et sociis suis.-Rex thesaurario et camerariis suis de scaccario Dublinensi, salutem. Liberate de thesauro nostro Coppo Josep', Coppo Cotenne et Taldo Janiani, et sociis suis, mercatoribus de societate Friscombaldorum de Florentia, vel eorum aut unius ipsorum certo attornato istud breve deferenti, undecim milia librarum sterlingorum, pro illis undecim milibus librarum sterlingorum quae iidem mercatores liberarunt, in garderoba nostra, dilecto clerico nostro Johanni de Drokenesford, custodi ejusdem garderobe, ad expensas hospitii nostri inde faciendas, et alia negotia nostra inde expedienda, et pro quibus, per litteras nostras patentes, concessimus et assignavimus, pro nobis et haredibus nostris, eisclem mercatoribus, ommes exitus et proficua quæcumque provenientia de terra nostra Hiberniæ, necnon et totan pecuniam in thesauro nostro nunc ibidem existentem; prout in litteris nostris predictis plenius continetur. Nisi prius liberationem illam feceritis, per aliud breve nostrum. Et recipiatis ab eisdem mercatoribus, seu attornato prædicto, quotienscumque contigerit vos aliquam pecunia summam sibi liberare, litteras suas patentes receptionem cujuslibet summa sibi liberatie testificantes. Et, cum predicta undecim milia librarum dictis 
mercatoribus vel predicto attornato persolveritis, recipiatis ab eis litteras nostras patentes priedictas duplicatas, necnon et litteras suas acquietantiæ receptionem illius summc similiter testificantes. 'T. R. apud Langeleye, xxj die Octobris.

CIX.

28 Edw. I. m. 4.-Pro Coppo Joseph' et sociis suis, mercatoribus de societate Friscobaldorum de Florentia.-Rex thesaurario et cameraris suis de scaccario, salutem. Liberate de thesauro nostro Coppo Joseph', Coppo Cotenne et Taldo Janiani, mercatoribus de societate Friscombaldorum de Florentia, mille trescentas quaterviginti et septem libras et duodecim solidos sterlingorum, pro illis septem milibus ducentis quaterviginti et quatuor libris, decem et octo solidis, Turonensium nigrorum, in quibus iidem mercatores obligarunt se, pro nobis, erga quosdam mercatores de Vasconia, pro illis duobus milibus trescentis et duodecim libris, tresdecim solidis et quatuor denariis, crokardorum, in quibus dictis mercatoribus Vasconiæe tenebamur, pro vinis ab ipsis, tam per Matheum de Columbariis quam per Adam de Rokesle, ad expensas hospitii nostri, tempore dilecti clerici nostri Johamnis de Drokenesford, custodis garderobæ nostræ, nuper emptis, etc. T. R. apud Pontem Fractum, viij die Junii.

\section{CX.}

28 Edw. I. m. 3.-Pro Coppo Joseph' et sociis suis, mercatoribus.-Rex, etc. Liberate de thesauro nostro Coppo Joseph' et Taldo Janiani, et eorum sociis, mercatoribus de societate Friscombaldorum de Florentia, mille septingentas quinquaginta et tres libras et octo denarios sterlingorum, quos, de voluntate et mandato venerabilis patris $W$. Corentrensis et Lichfeldensis episcopi, thesaurarii nostri, solverunt Arnaldo Guilliclmi, dicto Comiti Dandoyns, tam nomine suo quam nomine Arnaldi Willielmi de Bosco, Angeri de la Dins, Petri de Tutdieus, Arnaldi de la Garde, Remundi Arnaldi de Clavoria, Gaillardi du Pont, Arnaldi Guillielmi de Burdegala, Maurini de Mielsanz, Guillielmi Arnaldi de Sanguinieda et Arnaldi du Sages, hominum suorura, eandem pecuniam recipienti, in quibus præfato comiti et hominibus suis prædictis tenebamur; prout particulariter continetur in duodecim litteris sigillo dilecti consanguinei et fidelis nostri Henrici de Lacy comitis Lincolniæ, locum nostrum nuper tenentis in ducatu Aquitania, signatis, in quibus dictas mille septingentas quinquaginta et tres libras et octo denarios sibi, pro se et haredibus suis predictis, fatetur fuisse solutas. Fit recipiatis ab eisclem mercatoribus prædictas duodecim litteras sigillo dicti Comitis Lincolniæ sigillatas, una cum litteris ipsorum mercatorum testificantibus se prædictas mille septingentas quinquaginta et tres libras et octo denarios a nobis recepisse, et etiam litteras nostras patentes eisdem mercatoribus de præfata pecuniæ summa confectas. T. R. apud Eboracum, xiij die Junii. 


\section{CXI.}

29 Edw. I. m. 4.-Pro mercatoribus de societate Friscobaldorum.-Rex, etc. Liberate de thesauro nostro Coppo Cotenne, Taldo Janiani et eorum sociis, mercatoribus de societate Friscobaldorum de Florentia, quingentas marcas sterlingorum, pro quingentis marcis sterlingorum quas iidem mercatores, pro nobis et nomine nostro, solverunt Loterio de Blanco, pro quatuor dextrariis quos ab ipso habuimus : quas quidem quingentas marcas præfatis mercatoribus per litteras nostras patentes solvere promisimus, in festo Nativitatis S. Johannis Baptiste ultimo præterito. Et recipiatis ab eis litteras nostras prædictas. T. R. apud Wyrksope, iij die Decembris.

\section{CXII.}

32 Edw. I. m. 2.-Pro Roberto de Barton et Johanne de Hustchwayt.-Rex, etc. Allocate Roberto de Barton et Johanni de Hustchwayt, nuper collectoribus nostris novæ custumæ apud Kingeston super Hull, in compoto suo ad scaccarium prædictum, quingentas libras, quas, per breve nostrum de dicto scaccario, liberaverunt, anno regni nostri vicesimo quinto incipiente, de pecunia proveniente, eodem anno, de eadem custuma, Taldo Janiani et sociis suis, mercatoribus de societate Friscobaldorum Alborum, in partem solutionis debitorum in quibus eisdem mercatoribus ex mutuo tenebamur; et ducentas et triginta libras, duodecim solidos, quatuor denarios et unum obolum, pro custuma ad nos pertinente de centum et quatuordecim saccis et triginta et quatuor petris lanæ eorumdem mercatorum, quos ipsi, in portu prædicto, videlicet, quinquaginta et unum saccos et duodecim petras lanæ, anno regni nostri vicesimo quarto, et sexaginta et tres saccos et viginti et duas petras lanæ, anno regni nostri vicesimo quinto incipiente, transduci fecerunt quietos de custuma; quibus quidem collectoribus venerabilis pater W. Coventrensis et Lychfeldensis episcopus, thesaurarius noster, per litteras suas, ex parte nostra, mandavit ut ipsi dictos mercatores lanas illas, absque custuma inde solvenda, ad partes transmarinas ducere permitterent, in partem solutionis debitorum in quibus eisdem mercatoribus, in garderoba nostra, similiter tenebamur ; et ducentas libras, pro custuma ad nos pertinente de centum saccis lanæ diversorum mercatorum, quos quidem saccos lanæ Coluchius Ballard et socii sui, mercatores de Luka, in portu prædicto, anno regni nostri vicesimo quarto, transduci fecerunt quietos de custuma; quibus quidem collectoribus, per breve nostrum de dicto scaccario, mandavimus quod ipsi mercatores illos dictas lanas, absque custuma inde solvenda, ad partes Brabantiæ ducere permitterent, in partem solutionis debitorum in quibus eisdem mercatoribus, in garderoba nostra, tenebamur : etc. T. R. apud Stryvelyn, xv die Junii.

Per billam de scaccario. 


\section{CXIII.}

34 Edw. I. m. 3.-Pro Nicholao de Karliolo et Thoma filio Hugonis de Karliolo.-Rex, etc. Allocate Nicholao de Karliolo et Thomæ filio Hugonis de Karliolo, collectoribus custumæ lanarum, pellium lanutarum et coriorum, apud Novum Castrum super Tynam, mille centum viginti et septem libras, quinque denarios et unum obolum, quos, per litteras nostras patentes, de exitibus dictæ custumæ, liberaverunt Catelano Consorti et Bonencountre Jacobi, attornatis Berti Pennuchii, Stoldi de Friscobald', Coppi Cottenne et sociorum suorum, mercatorum de societate Friscobaldorum de Florentia, a primo die Aprilis anno regni nostri tricesimo secundo, usque quartum diem Aprilis anno regni nostri tricesimo quarto, in partem solutionis debitorum in quibus nos tenemur dictis mercatoribus, pro diversis pecuniarum summis nobis per ipsos mutuatis, pro arduis negotiis nostris inde expediendis; et etiam in partem solutionis decem milium librarum, quæ nos eisdem mercatoribus concessimus, de dono nostro, in recompensationem dampnorum et jacturarum quæ iidem mercatores sustinuerunt, ratione retardationis solutionis debitorum pradictorum : pro quibus quidem debitis, et dictis decem milibus librarum, concessimus eisdem mercatoribus, pro nobis et hæredibus nostris, custumam lanarum, pellium lanutarum et coriorum, in omnibus portubus et locis regni nostri Hiberniæ, habendam a primo die Aprilis anno regni nostri tricesimo secundo, quousque iidem mercatores vel unus eorum, aut certus attornatus eorumdem mercatorum aut unius eorum, tam prædicta decem milia librarum quam omnia alia debita sua, de mutuis prædictis, de custuma prædicta receperint vel receperit. Nisi prius inde allocationem habuerint, in toto vel in parte. Et recipiatis ab eis litteras nostras prædictas, necnon et quatuor litteras patentes dicti Catelani et duas dicti Bonencountre, attornatorum dictorum mercatorum, receptionem prædictarum mille centum viginti et septem librarum, quinque denariorum et unius oboli, testificantes. T. R. apud Wyntoniam, x die Maii.

\section{Per billam de scaccario.}

\section{CXIV.}

34 Edw. I. m. 3.-Rex, etc. Allocate, etc. ut supra, collectoribus novæ custumæ provenientis de lanis, pellibus lanutis, coriis, et aliis diversis mercandisis mercatorum extraneorum et alienigenarum, ultra antiquam custumam, nobis concessæ, in villa Novi Castri super Tynam, et abinde per costeram maris usque Berewycum super Twedam, sexaginta libras, duodecim solidos et decem denarios, quos, per litteras nostras patentes, de exitibus ejusdem novæ custumæ, etc. ut supra, a duodecim die Julii anno regni nostri tricesimo secundo, usque quartum diem Aprilis anno regni nostri tricesimo quarto, in partem solutionis debitorum in quibus nos tenemur eisdem mercatoribus, pro diversis pecunia summis, etc. ut supra, usque ad finem. T. ut supra. 
CXV.

34 Edw. I. m. 2.-Pro Richero de Refham et Hugone Pourt.-Rex, etc. Allocate Richero de Refham et Hugoni Pourt, collectoribus novæ custumæ provenientis de lanis, pellibus lanutis, coriis, et aliis diversis mercandisis mercatorum extraneorum et alienigenarum, ultra antiquam custumam, nobis concessæ, in portu Londonix, et in singulis locis ex utraque parte Thamisix usque Grenewycum, mille sexcentas et quinque libras, decem et novem solidos et unum quadrantem, quos, per litteras nostras patentes, de exitibus ejusdem custuma, liberaverunt Johanni Wulpis et Benchenino Belloti, attornatis Berti Pennuchii, Stoldi de Friscobaldis, Coppi Cotenne et sociorum suorum, mercatorum de societate Friscobaldorum de Florentia, a primo die Aprilis anno regni nostri tricesimo secundo, usque ad vigesimum quartum diem Junii anno regni nostri tricesimo quarto ; in partem solutionis diversorum debitorum in quibus tenemur dictis mercatoribus, ex diversis causis; et pro quibus quidem debitis concessimus et assignavimus eisclem mercatoribus dictam novam custumam de lanis et pellibus lanutis, et coriis, habendam in singulis portubus et locis regni Anglia et terra nostræ Hibernia, una cum praclicta antiqua custuma eis per nos prius, pro prædictis debitis, assignata, quousque dicti mercatores vel unus eorum, aut certus attornatus eorumdem mercatorum aut unius eorum, predicta debita receperint vel receperit. Nisi prius inde allocationem habuerint, in toto vel in parte. Et recipiatis, etc. T. R. apud Norhamptoniam, xxvj die Junii.

Per billam de scaccario.

\section{CXVI.}

34 Edw. I. m. 2.-Rex, etc. Allocate Richero de Refham et Hugoni Pourt, collectoribus antiqua custumæ nostræ lanarum, pellium lanutarum et coriorum, in Londonia, et in singulis locis ex utraque parte Thamisice usque Grenewycum, novem milia centum et sexaginta et decem et octo libras et viginti et unum denarios, quos, per litteras nostras patentes, de exitibus dicta antiqua custuma de lanis, pellibus lanutis et coriis, provenientis, liberaverunt Johanni de Wulpis et Benchenino Belloti, attornatis Berti Pennuchii, Stoldi de Friscobaldis, Coppi Cotenne et sociorum suorum, mercatorum de societate Friscobaldorum de Florentia, a primo die Aprilis anno regni nostri tricesimo secundo, usque quartum diem Aprilis anno regni nostri tricesimo quarto; in partem solutionis diversorum debitorum in quibus dictis mercatoribus, pro diversis pecuniarum summis nobis per ipsos mutuatis, pro arduis negotiis nostris inde expediendis, tenemur; et, etiam, in partem solutionis decem milium librarum, quæ nos eisdem mercatoribus concessimus, de dono nostro, in recompensationem dampnorum et jacturarum qua iidem mercatores sustinuerunt, ratione retardationis solutionum debitorum predictorum : pro quibus quidem debitis et dictis decem milibus librarum, concessimus eisdem mercatoribus, pro nobis et hæeredibus nostris, custumam lanarum, pellium lanutarum et coriorum, 
in omnibus portubus et locis regni Angliæ et terræ nostræ Hiberniæ, habendam a primo die Aprilis anno regni nostri tricesimo secundo, quousque iidem mercatores vel unus eorum, aut certus attornatus eorumdem mercatorum aut unius eorum, tam prædicta decem milia librarum quam omnia alia debita sua, de mutuis præedictis, de dicta custuma receperint vel receperit. Nisi prius inde allocationem habuerint, in toto vel in parte. Et recipiatis, etc. T. R. apud Norhamptoniam, xxvj die Junii.

\section{CXVII.}

35 Edw. I. m. 4.-Pro Waltero le Taverner et Adam Charles.-Rex, etc. Allocate Waltero le Taverner et Adam Charles, collectoribus novæ custumæ provenientis de lanis, pellibus lanutis, coriis, et aliis diversis mercandisis mercatorum extraneorum et alienigenarum, ultra antiquam custumam, nobis concessæ, in portu Sandwyci, excepta custuma vinorum ibidem, triginta et octo libras et novem solidos, quos, per litteras nostras patentes, de exitibus dictæ novæ custumæ, liberaverunt Betino de Friscobaldis, mercatori de societate Friscobaldorum de Florentia, in partem solutionis diversorum debitorum in quibus tenemur mercatoribus de dicta societate Friscobaldorum, ex diversis causis, etc. T. R. apud Lanrecost, $\mathrm{x}$ die Decembris.

\section{CXVIII.}

2 Edw. II. m. 5.-Pro Thoma le Rente et Ricardo Lew.-Rex, etc. Allocate Thomæ le Rente et Ricardo Lew, collectoribus antiquæ custumæ et novæ apud Gippeswycum, in exitibus ballivæ suæ, trescentas et triginta libras, duodecim solidos, tres denarios et. unum obolum, quos, per præceptum nostrum, de exitibus custumæ prædictæ, anno regni nostri primo, liberaverunt Johanni Hugonis, mercatori, et attornato Emerici de Friscobaldis et sociorum suorum, mercatorum de societate Friscobaldorum de Florentia, ad: opus ipsorum mercatorum: quibus quidem mercatoribus concessimus totam pecuniam provenientem de custumis predictis, percipiendam a tempore mortis domini E. quondam Regis Anglia, patris nostri, quousque ipsis mercatoribus de debitis in quibus eis tenemur plene fuerit satisfactum. Nisi prius, etc. Et recipiatis, etc. T. R. apud Westm. xxviij die Novembris.

\section{CXIX.}

2 Edw. II. m. 5.-Rex, etc. Allocate Lamberto de S. Omero et Johanni Lambert, collectoribus antiquæ et novæ custumæ nostræ lanarum, pellium lanutarum et coriorum, in portu Lenne, ducentas triginta libras, undecim solidos, undecim denarios et unum obolum, quos, per præceptum nostrum, de exitibus custumæ prædictæ, anno regni nostri primo, liberaverunt Gerardo Renouchi, mercatori, et attornato mercatorum de societate Friscobaldorum de Florentia, etc. ut supra. T. R. apud Westm. xxj die Novembris. 


\section{CXX.}

2 Edw. II. m. 4.-Pro mercatoribus de societate Friscobaldorum de Florentia.-Rex, etc. Mandamus vobis quod Coppo Joseph', Taldo Janiany, et eorum sociis, mercatoribus de societate Friscobaldorum de Florentia, id quod eis a retro est de mille septingentis quinquaginta et tribus libris et octo denariis sterlingorum, quos, de voluntate et mandato Walteri Coventrensis et Lychfeldensis episcopi, nuper thesaurarii domini Edwardi, quondam Regis Angliæ, patris nostri, solverunt Arnaldo Guillielmi, dicto Comiti Dandoyns, tam nomine suo quam nomine Arnaldi Guillielmi de Bosco, Angeri de la Dyns, Petri de Tutdieus, Arnaldi de Pardieus, Arnaldi de la Garde, Reymundi Arnaldi de Clavoria, Gaillardi du Pount, Arnaldi Guillielmi de Burdegala, Maurini de Mielsanz, Guillielmi Arnaldi de Sanguinieda et Arnaldi du Sages, hominum suorum, eandem solutionem recipienti, in quibus præfatus pater noster dicto Comiti et hominibus suis supradictis tenebatur, liberetis de thesauro nostro; juxta tenorem brevis dicti patris nostri de liberate, quod penes vos residet, in scaccario nostro. T. R. apud Stretford, xij die Martii.

\section{CXXI.}

2 Edw. II. m. 4.-Pro mercatoribus de Societate Friscobaldorum de Florentia.-Rex, etc. Mandamus vobis quod Coppo Joseph', Coppo Cotenne et Taldo Janiani, mercatoribus de societate Friscobaldorum de Florentia, id quod a retro est de mille trescentis quaterviginti et septem libris et duodecim solidis sterlingorum, pro illis septem milibus ducentis quaterviginti et quatuor libris et decem et octo solidis Turonensium Nigrorum, in quibus iidem mercatores obligarunt se pro domino Edwardo, quondam Rege Angliæ, patre nostro, erga quosdam mercatores de Vasconia, pro illis duobus milibus trescentis et duodecim libris, tresdecim solidis et quatuor denariis, Crocardorum, in quibus idem pater noster dictis mercatoribus Vasconiæ tenebatur, pro vinis ab ipsis, tam per Matheum de Columbariis quam per Adam de Rokesle, ad expensas hospitii dicti patris nostri, emptis, de thesauro nostro liberetis ; juxta tenorem brevis dicti patris nostri de liberate, quod penes vos residet, in scaccario nostro. Teste, ut supra.

\section{CXXII.}

2 Edw. II. m. 3.-Rex, etc. Allocate Thomæ Gysors et Johanni filio Thomæ de S. Botulpho, collectoribus antiquæ custumæ et novæ lanarum, pellium lanutarum et coriorum, in portu de S. Botulpho, quatuor milia quaterviginti et tresdecim libras, viginti denarios et unum obolum, quos, de exitibus custumæ prædictæ, a festo S. Michaelis, anno regni nostri primo, usque ad idem festum proximo sequens, per præceptum nostrum, liberaverunt Emerico de Friscobaldis et sociis suis, mercatoribus de societate Friscobaldorum de Florentia, in partem solutionis debitorum in quibus dominus Edwardus, 
quondam Rex Angliæ, pater noster, tenebatur mercatoribus antedictis. Nisi prius, etc. Et recipiatis ab eis breve nostrum de præcepto, per quod dictam pecuniam præfatis mercatoribus liberaverunt, necnon quatuor indenturas inter ipsos Johannem et Thomam et Paulum de Cano Rubeo de Florentia, attornatum dictorum mercatorum, in hac parte factas, receptionem ejusdem pecuniæ testificantes. T. $R$. apud Langele, xxviij die Aprilis.

\section{CXXIII.}

2 Edw. II. m. 3.-Pro Philippo Burge, mercatore de societate Mozorum de Florentia.Rex, etc. Liberate de thesauro nostro Philippo Bourge, mercatori de societate Mozorum de Florentia, mille centum et decem et septem libras; et Johanni de Circulis Nigris, mercatori de societate Circulorum Nigrorum de Florentia, mille octingentas et triginta et sex libras sterlingorum; in forma per nos vobis, super hoc, per litteras sub privato sigillo nostro, plenius demandata. T. R. apud Westm. vj die Maii.

\section{CXXIV.}

2 Edw. II. m. 2.-Rex, etc. Allocate Roberto de Barton et Gilberto de Bedeford, collectoribus tam antiquæ quam novæ custumæ lanarum, pellium lanutarum et coriorum, in portu de Kingston super Hull, in compoto suo ad scaccarium predictum, duo milia sexcentas tresdecim libras, decem solidos et undecim denarios, quos, per præceptum nostrum, de exitibus novæ custumæ prædictæ, liberaverunt Bettino Friscobaldi, mercatori de societate Friscobaldorum de Florentia, ad opus suum et sociorum suorum prædictorum : quibus quidem mercatoribus concessimus totam pecuniam de custumis prædictis provenientem, percipiendam a tempore mortis domini E. quondam Regis Angliæ, patris nostri, quousque sibi de eo quod eis a retro fuerit, tam de debitis quæ dictus pater noster eis debebat quam de debitis in quibus nos tenemur eisdem, plene fuerit satisfactum. Nisi prius, etc. Et recipiatis, etc. T. R. apud Kenyngton, xxvij die Maii.

\section{CXXV.}

2 Edw. II. m. 2.-Pro mercatoribus de societate Friscobaldorum de Florentia.-Rex, etc. Liberate de thesauro nostro Emerico de Friscobaldis et sociis suis, de societate Friscobaldorum de Florentia, duo milia ducentas viginti et duas libras, decem et septem solidos, novem denarios et unum obolum, sterlingorum, pro illis decem milibus librarum bonorum parvorum Turonensium quæ iidem mercatores, pro nobis, solverunt Johanni de Cabilone domino Darlay, pro tanta pecuniæ summa in qua dominus E. quondam Rex Angliæ, pater noster, per suas litteras patentes, præfato Johanni et quibusdam nobilibus de Burgundia tenebatur, de dono suo speciali. Et, facta liberatione prædicta, recipiatis ab eis litteras patentes antedictas. T. R. apud Westm. xj die Junii. 
CXXVI.

2 Edw. II. m. 1.-Rex, etc. Allocate Roberto de Barton et Gilberto de Bedeford, nuper collectoribus antiquæ custumæ lanarum, pellium lanutarum et coriorum, apud Kingeston super Hull, in compoto suo ad scaccarium prædictum, octo milia quingentas et tresdecim libras, undecim solidos, quinque denarios, unum obolum et unum quadrantem, quos, per præceptum domini E. quondam Regis Angliæ, patris nostri, de exitibus dictæ custumæ, liberaverunt Petro Bonavint et Coppino Cotenne, attornatis Bettini Friscobaldi et Coppi Cotenne, et sociorum suorum, mercatorum de societate Friscobaldorum de Florentia: quibus quidem mercatoribus dictus pater noster, pro diversis debitis in quibus eis tenebatur, pro diversis pecuniarum summis ei per ipsos mutuatis, pro arduis negotiis suis inde expediendis, ac pro decem milibus librarum quæe eisdem mercatoribus concessit, de dono suo, in recompensationem dampnorum et jacturarum quæ iidem mercatores, ratione retardationis solutionis debitorum illorum, sustinuerunt, concessit, pro se et hæredibus suis, custumam prædictam, in omnibus portubus et locis regni nostri Angliæ et terræ nostræ Hiberniæ, habendam a primo die Aprilis anno regni dicti patris nostri tricesimo secundo, eodem die computato, quousque, etc. Nisi prius, etc. Et recipiatis, etc. T. ut supra.

\section{CXXVII.}

2 Edw. II. m. 2.-Rex, etc. Allocate Roberto de Barton et Gilberto de Bedeford, nuper collectoribus novæe custumæ quaterviginti denariorum de lanis et pellibus lanutis, et dimidice marcæ de lasta coriorum, in portu de Kingeston super Hull, in compoto suo ad scaccarium prædictum, duo milia sexcentas sex libras, duodecim solidos, duos denarios, unum obolum et unum quadrantem, quos, per præceptum domini E. patris nostri, etc. ut supra. T. ut supra.

\section{CXXVIII.}

2 Edw. II. m. 1.-Pro Willielmo Fastolfe et Willielmo de la Mawe.-Rex, etc. Allocate Willielmo Fastolfe et Willielmo de la Mawe, nuper collectoribus novæ custumæ quadraginta denariorum de lanis et pellibus lanutis, et dimidiæ marcæ de lasta coriorum, apud Jernemuth', in compoto suo ad scaccarium predictum, sexaginta et decem et octo libras, sex solidos, decem denarios, unum obolum et unum quadrantem, quos, per præceptum domini E. quondam Regis Angliæ, patris nostri, de exitibus custumæ prædictæ, liberaverunt Chenino du Val, Galfrido Teste, et Berto de Cauche, attornatis Emerici et Bettini de Friscobaldis, et Coppi Cotenne, et sociorum suorum, mercatorum de societate Friscobaldorum de Florentia : quibus quidem mercatoribus dictus pater noster, volens maturare solutionem debitorum in quibus dictis mercatoribus tenebatur, ex diversis 
causis, concessit et assignavit custumam prædictam, habendam, in singulis portubus regni nostri Angliæ et terræ nostræ Hiberniæ, una cum antiqua custuma prius eis per eundem patrem nostrum assignata, quousque dicti mercatores vel unus eorum, etc. Nisi prius, etc. Et recipiatis, etc. T. R. apud Westm. v die Junii.

\section{CXXIX.}

2 Edw. II. m. 2.-Rex, etc. Allocate præefatis Willielmo et Willielmo, collectoribus tam antiquæ quam novæ custumæ nostræ lanarum, coriorum et pellium lanutarum, in portu de Jernemuta, centum quaterviginti undecim libras, sexdecim solidos, unum denarium, unum obolum et unum quadrantem, quos, per præceptum nostrum, de exitibus custumarum prædictarum, liberaverunt Berto de Cauche, attornato Emerici de Friscobaldis et sociorum suorum, mercatorum de societate Friscobaldorum de Florentia : quibus quidem mercatoribus, etc. ut supra. T. R. ut supra.

\section{CXXX.}

2 Edw. II. m. 1.-Pro Willielmo Fastolfe et sociis suis.-Rex, etc. Allocate Willielmo Fastolfe et sociis suis, collectoribus custumæ lanarum, pellium lanutarum et coriorum, apud Jernemuth, in compoto suo ad scaccarium prædictum, septingentas et tres libras, andecim solidos et septem denarios, quos, per præceptum domini E. quondam Regis Angliæ, patris nostri, liberaverunt Nuchio Sek', attornato Guidonis Bardi, mercatoris de societate Spinorum de Florentia, pro mercatoribus de societate prædicta et aliis diversis societatibus, quibus dictus pater noster in viginti et octo milibus nongentis sexaginta et sex libris et una marca tenebatur, et quibus idem pater noster assignavit et concessit, pro se et hæredibus suis, omnes exitus provenientes de custuma predicta, in portu prædicto et in omnibus aliis portubus regni nostri, per manus alicujus mercatoris quem iidem mercatores ad hoc assignare vellent percipiendos, quousque eisdem mercatoribus de summa pecuniæ eis debita plenarie fuisset satisfactum; ad recipiendum, ad opus eorumdem mercatorum, omnes exitus supradictos, in portu prædicto, assignato. Nisi prius, etc. Et recipiatis, etc. T. R. apud Daventre, xxij die Junii.

\section{CXXXI.}

2 Edw. II. m. 1.-Pro Willielmo Fastolfe et Waltero Brun.-Rex, etc. Allocate Willielmo Fastolfe et Waltero Broun de Jernemuth, nuper collectoribus custumæ lanarum, pellium lanutarum et coriorum, in portu de Jernemuth, in compoto suo ad scaccarium prædictum, sexdecim libras et undecim solidos, quos, per præceptum domini Edwardi, quondam Regis Angliæ, patris nostri, de exitibus de custuma prædicta, a septimo die Maii, anno regni dicti patris nostri vicesimo septimo, usque ad vigiliam Pentecostes 
proximo sequentem, provenientibus, liberaverunt Nuchio Sek' de Luca, attornato Coppi Joseph', mercatoris de societate Friscobaldorum de Florentia. Nisi prius, etc. Et recipiatis, etc. T. ut supra.

\section{CXXXII.}

3 Edw. II. m. 3.-Pro Lamberto de Sancto Omero et Johanne Lambert.-Rex, etc. Allocate Lamberto de Sancto Omero et Johanni Lambert, nuper collectoribus tam antiquæ quam novæ custumæ nostræ lanarum, pellium lanutarum et coriorum, in portu de Lenne, in compoto suo ad scaccarium, centum et quinquaginta et unum libras, duodecim solidos, tres denarios et unum obolum, quos, de exitibus dictæ antiquæ custumæ, in dicto portu, a festo S. Michaelis anno regni nostri secundo, usque ad festum Paschæ proximo sequens, provenientes, per præceptum nostrum, liberaverunt Gerardo Renuchi, attornato Emerici de Friscobaldis et sociorum suorum, mercatorum de societate Friscobaldorum de Florentia, in partem solutionis diversarum pecuniæ summarum in quibus dominus E. quondam Rex Anglize, pater noster, eisdem mercatoribus tenebatur, et decem milium librarum quæ idem pater noster dictis mercatoribus concesserat, de dono suo; necnon et quorumdam debitorum in quibus eis tenemur; et centum et viginti et tres libras, tresdecim solidos et sex denarios, quos, de exitibus dictæ antiquæ custumæ, a prædicto festo Paschæ usque ad primum diem Augusti proximo sequentem, ibidem provenientes, similiter, per præceptum nostrum, liberaverunt Vachino Cheste, attornato dictorum mercatorum, in partem solutionis dictorum decem milium librarum et debitorum prædictorum; et sex libras, sex solidos et decem denarios, quos, de exitibus dictæ novæ custumæ, in prædicto portu, a dicto festo $\mathbf{S}$. Michaelis usque ad prædictum festum Paschæ, provenientes, per præceptum nostrum, similiter liberaverunt præfato Gerardo, in partem solutionis, etc.; et quatuor libras, undecim solidos, septem denarios, unum obolum et unum quadrantem, quos, de exitibus ejusdem novæ custumæ, in dicto portu, a prædicto festo Paschæ usque ad dictum primum diem Augusti, provenientes, similiter, per præceptum nostrum, liberaverunt præfato Vachio, in partem solutionis, etc. Et recipiatis, etc. T. R. apud Hereford', xxix die Januarii.

Et memorandum quod Petrus de Friscobaldis, unus mercatorum de societate prædicta, venit in cancellariam Regis, apud Westmonasterium, et fatebatur, pro se et sociis suis, mercatoribus de eadem societate, quod prædicti Gerardus et Vachius fuerunt eorum attornati, in hac parte.

\section{CXXXIII.}

3 Edw. II. m. 3.-Rex, etc. Allocate Simoni de Gysors, executori Thomæ de Gysors, nuper unius collectorum tam antiquæ quam novæ custumæ nostræ lanarum, pellium lanutarum et coriorum, ac aliarum custumarum pannorum, speceriæ, et aliarum rerum 
minutarum, in portu villæ de S. Botulpho, ducentas sexaginta et sex libras, duodecim solidos et duos denarios, quos iidem collectores, de exitibus dietæe antiquæ custumæ, in portu prædicto, a festo S. Michaelis anno secundo, usque ad festum S. Martini proximo sequens, per præceptum nostrum, liberaverunt Paulo de Cano Rubeo de Florentia, attornato Emerici de Friscobaldis et sociorum suorum, mercatorum de societate Friscobaldorum de Florentia, in partem solutionis diversarum pecuniæ summarum, in quibus dominus E. quondam Rex Angliæ, pater noster, eisdem mercatoribus, die quo obiit, ex mutuo tenebatur, et decem milium librarum, quæ idem pater noster dictis mercatoribus concesserat, in recompensationem, etc. de dono suo; necnon et quorumdam debitorum in quibus eis tenemur; et quingentas viginti et octo libras, decem et octo solidos et septem denarios, quos iidem collectores, de exitibus dictæ antiquæ custumæ, ab eodem festo S. Martini usque ad primum diem Aprilis proximo sequentem, ibidem provenientes, similiter, per præceptum nostrum, liberaverunt Petro Boniovint de Florentia, attornato dictorum mercatorum, in partem solutionis dictorum decem milium librarum et debitorum prædictorum; et ducentas quinquaginta et unam libras et decem solidos, quos iidem collectores, de exitibus dictæ antiquæ custumæ, ab eodem primo die Aprilis usque ad vicesimum septimum diem Junii proximo sequentem, ibidem provenientes, similiter, per præceptum nostrum, liberaverunt prædicto Petro, in partem solutionis decem milium librarum et debitorum prædictorum; et duo milia sexcentas quinquaginta et quinque libras, quatuordecim solidos, unum denarium et unum obolum, quos iidem collectores, de exitibus dictæ antiquæ custumæ, ab eodem vicesimo septimo die Junii usque ad festum S. Michaelis proximo sequens, ibidem provenientes, similiter, etc.; et quinquaginta et sex libras, duodecim solidos et duos denarios, quos iidem collectores, de exitibus dictæ novæ custumæ, a festo S. Michaelis anno secundo, usque festum S. Martini proximo sequens, ibidem provenientes, similiter, etc.; et quadraginta et quinque libras, quatuordecim solidos, novem denarios et unum obolum, quos iidem collectores, de exitibus dictæ novæ custumæ, ab eodem festo S.Martini usque ad primum diem Aprilis proximo sequentem, ibidem provenientes, similiter, etc.; et triginta et novem libras, decem et septem solidos, octo denarios, unum obolum et unum quadrantem, quos iidem collectores, de exitibus dictæ novæ custumæ, a prædicto primo die Aprilis usque ad vicesimum septimum diem Junii, ibidem provenientes, similiter, etc.; et octingentas quadraginta et duas libras, quatuordecim solidos, septem denarios, unum obolum et unum quadrantem, quos iidem collectores, de exitibus dictæ novæ custumæ, a prædicto ricesimo septimo die Junii usque ad festum S. Michaelis proximo sequens, similiter, etc.; et ducentas et quinquaginta et quinque libras, quas iidem collectores, de exitibus dictarun custumarum pannorum, speceriæ, et aliarum rerum minutarum, ibidem provenientes, similiter, per præceptum nostrum, liberaverunt præfato Petro, in partem solutionis debitorum prædictorum. Nisi prius, etc. T. R. apud Westm. $\mathrm{x}$ die Februarii. 
Et memorandum quod Lapus, clericus, et unus mercatorum de societate prædicta,. venit in cancellariam Regis, apud Westmonasterium, et fatebatur quod prædicti Petrus. et Paulus fuerunt attornati ipsorum mercatorum, in hac parte.

\section{CXXXIV.}

3 Edw. II. m. 3.- Rex, etc. Allocate Johanni filio Thomæ, Stephano de Stanham, Galfrido de Sutton et Michaeli de Moliar', nuper collectoribus novæ custumæ lanarum, pellium lanutarum et coriorum, in portu villæ de S. Botulpho, quingentas quaterviginti decem et octo libras, octo solidos et unum denarium, quos, de exitibus dictæe custumæ, a decimo die Februarii anno regni domini Edwardi quondam Regis Angliæ, patris nostri, tricesimo primo, usque ad primum diem Aprilis anno regni dicti patris nostri tricesimo secundo, provenientes, per præceptum dicti patris nostri, liberaverunt Jacobo Hugolini de Luka, attornato Berti Pennuchii et sociorum suorum, de societate Friscobaldorum de Florentia, in partem solutionis quorumdam debitorum in quibus idem pater noster præfatis mercatoribus tenebatur; et sexaginta et sex libras et undecim denarios, quos iidem collectores, de exitibus prædictæ custumæ, a dicto primo die Aprilis usque ad quartum decimum diem Julii proximo sequentem, similiter liberaverunt prædicto Jacobo, in partem solutionis debitorum prædictorum. Nisi prius, elc. Et recipiatis, etc. T. R. apud Westm. xv die Februarii.

\section{CXXXV.}

4 Edw. II. m. 3.-Pro mercatoribus de societate Bardorum de Florentia.-Rex, etc. Liberate de thesauro nostro Manetto Francisci, Tegio de Aye et sociis suis, mercatoribus de societate Bardorum de Florentia, vel uni eorum, duo milia librarum, pro illis duobus milibus librarum quæ dicti mercatores nobis mutuo liberarunt, ad quadam ardua negotia nostra inde expedienda. T. R. apud Berewicum super Twedam, xvj die Decembris.

\section{CXXXVI.}

6 Edw. II. m. 2,-Rex, etc. Liberate de thesauro nostro dilectis mercatoribus nostris Manente Francisci et sociis suis, mercatoribus de societate Bardorum de Florentia, duo milia librarum, quæ eis, per litteras nostras patentes, concessimus, de dono nostro, in recompensationem dampnorum et jacturarum quæ incurrerunt, ratione retardationis solutionum diversorum debitorum de quibus nobis, a tempore quo regimen regni nostri suscepimus, mutuum gratanter fecerunt. Et, facta liberatione prædicta, recipiatis a præfatis mercatoribus nostras litteras antedictas. T. R. apud Wyndesoram, xv dieAprilis.

Per ipsum Regem. 


\section{CXXXVII.}

6 Edw. II. m. 1.-Rex, etc. Liberate de thesauro nostro dilectis mercatoribus nostris Manento Francisci et sociis suis, mercatoribus de societate Bardorum de Florentia, quadringentas triginta et unam libras, quinque solidos et tres denarios, in quibus eis tenemur, de claro, de diversis pecuniarum summis quas sibi debebamus, sicut per certificationem per vos, præfati locum tenens et barones nostri de scaccario nostro, ad mandatum nostrum, nobis inde factam, plene liquet. T. J. Bathoniensi etWellensi episcopo, apud Cantuariam, vj die Aprilis.

\section{CXXXVIII.}

Per ipsum Regem.

7 Edw. II. m. 3.-Pro Manento Francisci et sociis suis, mercatoribus de societate Bardorum.-Rex, etc. Liberate de thesauro nostro, in festo Purificationis beatæ Mariæ Virginis proximo futuro, dilectis mercatoribus nostris Manento Francisci et sociis suis, mercatoribus de societate Bardorum de Florentia, tria milia septingentas et quindecim libras et decem et octo solidos, sterlingorum, in quibus eis tenemur ; videlicet, mille ducentas sexaginta decem et novem libras et quinque denarios, per ipsos, in garderoba nostra, tam pro expensis hospitii nostri et Isabellæ Reginæ Angliæ, consortis nostræ karissimæ, quam pro diversis negotiis nostris inde faciendis, anno regni nostri septimo, solutos; et quadringentas libras, dilecto clerico nostro Johanni de Sandale, ad quasdam solutiones, pro negotiis nostris, inde faciendas, eodem anno, per ipsos solutas; et mille nongentas sexaginta et sexdecim libras, sexdecim solidos et quatuor denarios, pro pannis ab eis per dilectum clericum nostrum Radulphum de Stokes, clericum magnæ garderobæ nostræ, eodem anno et anno regni nostri sexto, ad opus nostrum, emptis; et viginti et quinque libras et quinque solidos, quos Johanni de Goldeneth, pro carnibus et pisce, tam per Robertum Turk quam per Godeneton' de Spray, annis regni nostri tertio et quinto, emptis, ad opus nostrum; et octo libras, decem et novem solidos et tres denarios, quos Ricardo de Gerseie, pro tot denariis per ipsum, in garderoba prædicta, ad expensas familiæe nostræ et prædictæ consortis nostræ, apud Montem Trolli, dicto anno regni nostri sexto, mutuo liberatis ; et decem libras et decem et septem solidos, quos magistro Martino de Vear, cirurgico nostro, pro tot denariis in quibus eidem Martino, pro vadiis suis et expensis suis, inter primum diem Februarii anno regni nostri quarto, et septimum diem Julii proximo sequentem, et pro restauro unius somerii sui mortui, tenebamur; et quindecim libras, quas Pucheo de Portinal', pro panno ab eo per præfatum Radulphum de Stokes, eodem anno et anno regni nostri tertio supradicto, ad opus nostrum, empto-pro nobis solverunt: quas quidem pecuniæ summas eisdem mercatoribus, in dicto festo Purificationis beatæ Mariæ, per nostras patentes litteras, sol- 
vere promittimus, bona fide. Et, facta liberatione prædicta, recipiatis ab eisdem mercatoribus nostras litteras supradictas. T. R. apud Menstre in Insula de Taneto, vij die Decembris.

\section{CXXXIX.}

8 Edw. II. m. 4.-Pro Antonio Pessaigne.-Rex, etc. Liberate de thesauro nostro dilecto mercatori nostro Antonio Pessaigne de Janua quingentas marcas, quas, pro expeditione negotiorum nostrorum, nobis, per manus vestras, mutuo liberavit; quas quidem quingentas marcas eidem Antonio, citra quindenam Paschæ proximo futuram, per manus vestras, de thesauro nostro, solvere promisimus, bona fide. Et, facta liberatione, etc. 'T. R. apud Langele, vj die Januarii.

\section{CXL.}

8 Edw. II. m. 4.-Pro mercatoribus de societate Bardorum.-Rex, etc. Liberate de thesauro nostro dilectis mercatoribus nostris Manento Francisci et sociis suis, mercatoribus de societate Bardorum de Florentia, in quindena Paschæ proximo futura, mille marcas, pro illis mille marcis quas nuper liberarunt in thesaurariam nostram; et quas eis promisimus solvere, ad scaccarium nostrum, in dicta quindena. Et, facta liberatione, etc. T. R. apud Westm. vijj die Februarii.

\section{CXLI.}

8 Edw. II. m. 3.-Pro mercatoribus de societate de Perruches de Florentia.-Rex, etc. Liberate de thesauro nostro dilectis nobis Johanni Rustekyn et sociis suis, mercatoribus de societate de Perruches de Florentia, ducentas libras, citra festum Pentecostes proximo futurum, pro illis ducentis libris quas dicti mercatores nobis nuper mutuo liberarunt, in thesaurariam nostram, ad scaccarium nostrum, pro negotiis nostris inde expediendis ; et quas eis, citra dictum festum, per litteras nostras patentes, solvere promisimus, bona fide. Et, facta liberatione, etc. T. R. apud Westm. xxvij die Februarii.

\section{CXLII.}

8 Edw. II. m. 3.-Pro Ingelramo de Maregny et Totto Guidi.-Rex, etc. Liberate de thesauro nostro Ingelramo de Maregny et 'Totto Guidi, aut Vanno Forteguerr', ipsorum attornato, in festo Paschæ proximo futuro, ducentas libras, pro illis ducentis libris quas, per manus prædicti Vanni, ipsorum attornati, liberarunt nobis in thesaurariam nostram, ad scaccarium nostrum, pro negotiis nostris inde expediendis; et quas eisdem Ingelramo et Totto, aut præfato Vanno, ipsorum nomine, in prædicto festo, per litteras nostras patentes, solvere promisimus, bona fide. T. R. apud Westm. secundo die Martii. 


\section{CXLIII.}

8 Edw. II. m. 3.-Pro mercatoribus de societate Bardorum de Florentia.-Rex, etc. Liberate de thesauro nostro dilectis mercatoribus nostris Manento Francisci et sociis suis, mercatoribus de societate Bardorum de Florentia, sexcentas et duodecim libras, et septem solidos et unum denarium, pro tot denarïs per ipsos solutis, pro diversis negotiis nostris, anno regni nostri septimo; de quibus dicti mercatores quandam billam, summam prascriptam continentem, sigillo dilecti clerici nostri Ingellardi de Warle, tunc custodis garderobæ nostræ, signatam, in cancellariam nostram liberarunt: quos quidem ducentas et duodecim libras, septem solidos et unum denarium, prafatis mercatoribus nostris, in festo Purificationis beatæ Mariæ, anno supradicto, per nostras patentes litteras, solvere promisimus, bona fide. Et, facta liberatione, etc. T. R. apud Westm. $\mathbf{x v}$ die Martii.

\section{CXLIV.}

8 Edw. II. m. 3.-Rex, etc. Allocate . . . . collectoribus custumæ lanarum, pellium lanutarum et coriorum, in portu villæ de Kingston' super Hull, duo milia nongentas triginta et tres libras, quinque solidos, sex denarios et unum obolum, quos, per præceptum nostrum, liberaverunt Johanni de Sandale, in partem solutionis trium milium trescentarum quinquaginta et novem librarum, quatuor solidorum et unius denarii, in quibus eidem Johanni tenebamur; et trescentas quinquaginta et duas libras, decem et septem solidos, decem denarios et unum obolum, quos prædicti collectores liberarunt Jaketto de Sene, attornato Merlini de Sene, et in quibus eidem Merlino tenebamur. Nisi prius, etc. Et recipiatis, etc. T. R. apud Westm. primo die Maii.

\section{CXLV.}

10 Edw. II. m. 3.-Pro mercatoribus de societate Bardorum.-Rex, etc. Liberate de thesauro nostro dilecto nobis Doffo de Barde et sociis suis, mercatoribus de societate Bardorum de Florentia, centum libras, pro illis centum libris quas nobis, pro munitione quarumdam navium nostrarum, versus villam nostram Berewyci super Twedam mittendarum, mutuo liberarunt. T. R. apud Westm. xxj die Julii.

\section{CXLVI.}

10 Edw. II. m. 2.-Pro mercatoribus de societate Bardorum.-Rex, etc. Liberate dilectis mercatoribus nostris Doffo de Barde, Rogero Ardingelli et Dyno Forcetti, vel uni eorum, pro se et sociis suis, mercatoribus de societate Bardorum de Florentia, de denariis quos, de sextadecima, a communitate regni nostri, et decima, a clero ejusdem regni, nobis concessis, ad scaccarium nostrum deferri contigerit, septem milia septingentas quaterviginti et septem libras, novem solidos et duos denarios, pro sex milibus 
marcarum, quæ dicti mercatores, pro quibusdam arduis negotiis nos contingentibus, in partibus Vasconiæ, dilecto et fideli nostro Antonio de Pessaigne de Janua, et pro quadringentis libris, quas dilecto consanguineo et fideli nostro Rogero de Mortuo Mari de Wygemor, qui, in obsequium nostrum, per præceptum nostrum, profecturus est ad partes Hiberniæ, pro nobis solverunt; et pro tribus milibus trescentis quaterviginti et septem libris, novem solidis et duobus denariis, quos iidem mercatores pro nobis solvere promiserunt, pro vasis argenteis et aliis jocalibus, tam ad opus nostrum quam ad opus Isabellæ Reginæ Angliæ, consortis nostræ carissimæ, emendis, quæ domino Summo Pontifici presentari debent, ac pro expensis nunciorum nostrorum ad dictum Summum Pontificem destinatorum, et pro passagio eorumdem in portu Dovor' versus curiam Romanam, et pro diversis expensis in eadem curia faciendis : de quibus quidem septem milibus septingentis quaterviginti et septem libris, novem solidis et duobus denariis, liberetis eisdem mercatoribus tria milia trescentas quaterviginti et septem libras, novem solidos et duos denarios, de primis denariis provenientibus de primo termino solutionis sextædecimæ et decimæe prædictarum, et residua quatuor milia et quadringentas libras de primis denariis provenientibus de secundo termino solutionis sextædecimæ supradictæ. Et, facta liberatione prædicta, recipiatis a præfato Doffo, Rogero et Dyno, etc. T. R. apud Notyngham, iiij die Januarii.

\section{CXLVII.}

10 Edw. II. m. 1.-Pro mercatoribus de societate Bardorum.-Rex, etc. Liberate de thesauro nostro dilectis mercatoribus nostris Doffo de Barde, Rogero Ardingelli et Dino Forcinetti, et sociis suis, mercatoribus de societate Bardorum de Florentia, mille marcas; videlicet, quingentas marcas citra festum Nativitatis S. Johannis Baptistre proximo futurum, et quingentas marcas infra tres septimanas post idem festum proximo sequentes; quas nobis in thesaurariam nostram, per manus vestras, pro quibusdam negotiis nostris inde expediendis, mutuo liberarunt, et quas, per litteras nostras patentes, præfatis mercatoribus, ad terminos prædictos, solvere promisimus, bona fide. Et, facta liberatione, etc. T. R. apud Westm. x die Junii.

\section{CXLVIII.}

10 Edw. II. m. 1.-Pro mercatoribus de societate Bardorum.-Rex, etc. Liberate de thesauro nostro dilectis mercatoribus nostris Doffo de Barde, Rogero Ardingelli et Dino Forcinetti, et sociis suis, mercatoribus de societate Bardorum de Florentia, quatuor milia marcarum, citra festum S. Michaelis proximo futurum, quæ eis, per litteras nostras patentes, pro bono servitio quod nobis impenderunt, ac in recompensationem dampnorum et jacturarum quæ sustinuerunt, ratione retardationis solutionis quarumdam pecuniarum summarum in quibus sibi tenebamur, concessimus, ultra illas pecuniæ summas quas eis, 
ex hujusmodi causa, ante hæc tempora, concessimus; percipiendas ad scaccarium nostrum, citra terminum prædictum, de exitibus regni nostri, de dono nostro. T. R. apud Westm. xvij die Junii.

\section{CXLIX.}

10 Edw. II. m. 1.-Rex, etc. Liberate de thesauro nostro dilectis mercatoribus nostris Duffo de Barde, Rogero Ardyngelli et Dino Forcinetti, et sociis suis, mercatoribus de societate Bardorum de Florentia, mille sexcentas quaterviginti et duodecim libras, tres solidos et quatuordecim denarios, citra festum S. Michaelis proximo futurum, quos nobis in thesaurariam nostram, per manus vestras, pro negotiis nostris inde expediendis, mutuo liberarunt, et quas, per litteras nostras patentes, præfatis mercatoribus, ad dictum festum, solvere promisimus, bona fide. Et, facta liberatione, etc. T. R. apud Norhamton', vj die Julii.

\section{CL.}

11 Edw. II. m. 3.-Pro mercatoribus de societate Bardorum.-Rex, etc. Liberate de thesauro nostro dilectis mercatoribus nostris, Doffo de Barde, Rogero Ardingelli, Dino Forcinetti et Francisco Balduch', et sociis suis, mercatoribus de societate Bardorum de Florentia, vel uni eorum, mille et centum marcas, quas nobis in thesaurariam nostram, per manus vestras, præfate thesaurarie, pro quibusdam negotiis nostris inde expediendis, mutuo liberarunt, et quas eisdem mercatoribus vel uno eorum, citra festum S. Michaelis proximo futurum, per litteras nostras patentes, solvere promisimus, bona fide. T. R. apud Notingham, v die Augusti.

\section{CLI.}

11 Edw. II. m. 2.-Pro mercatoribus de societate Bardorum.--Rex, etc. Liberate de thesauro nostro dilectis mercatoribus nostris Doffo de Barde, Rogero Ardingelli, Dino Forcinetti et Francisco Balduch', quinquaginta et septem libras, quas nobis, per manus vestras, mutuo liberarunt, et in quibus eisdem mercatoribus tenemur, per litteras nostras patentes. Et, facta liberatione, etc. T. R. apud Wyndesoram, $\mathrm{xx}$ die Decembris.

\section{CLII.}

11 Edw. II. m. 2.-Pro mercatoribus de societate Bardorum.-Rex, etc. Liberate de thesauro nostro dilectis mercatoribus nostris Rogero Ardingelli, Dino Forcetti et Francisco Balduch', ac sociis suis, mercatoribus de societate Bardorum de Florentia, vel uni eorum, citra festum Pentecostes proximo futurum, octingentas et quadraginta libras; videlicet, quadraginta libras, quas nobis in garderobam nostram, per manus dilecti clerici nostri Roberti de Wodehouse, tenentis locum dilecti clerici nostri Rogeri de Northburgh', custodis ejusdem garderobæ, pro diversis solutionibus; et octingentas libras, 
quas nobis in eandem garderobam nostram, per manus ejusdem Roberti, pro expensis hospitii nostri, mensibus Martii et Aprilis, anno præsente, inde faciendis - mutuo liberarunt; sicut per duas billas sigillo ipsius Roberti signatas, quas iidem mercatores penes se habent, plenius apparet; et quas octingentas et quadraginta libras eisdem mercatoribus, citra festum prædictum, per nostras patentes litteras, solvere promisimus. Et, facta liberatione, etc. T. R. apud Mortelake, xij die Aprilis.

\section{CLIII.}

11 Edw. II. m. 2.-Pro mercatoribus de societate Bardorum.--Rex, etc, Liberate de thesauro nostro dilectis mercatoribus nostris Rogero Ardingelli, Dino Forcetti, Francisco Balduch' ac sociis suis, mercatoribus de societate Bardorum de Florentia, vel uni eorum, citra festum Pentecostes proximo futurum, quadringentas libras, quas nobis in thesaurariam nostram, per manus vestras, liberarunt, pro quibusdam negotiis nostris inde expediendis, et quas eisdem inercatoribus, citra festum prædictum, per nostras patentes litteras, solvere promisimus, bona fide. T. R. apud Wyndesoram, xv die Aprilis.

\section{CLIV.}

11 Edw. II. m. 2.-Pro mercatoribus de societate Bardorum.-Rex, etc. Liberate de thesauro nostro dilectis mercatoribus nostris Rogero Ardingelli, Dino Forcetti, Francisco Balduch' ac sociis suis, mercatoribus de societate Bardorum de Florentia, vel uni eorum, citra quindenam Paschæe proximo futuram, quadringentas marcas, quas iidem: mercatores, coram nobis, apud Westmonasterium, ad opus Isabellæ Reginæ Angliæ, consortis nostræ karissimæ, solvere concesserunt in garderoba ipsius consortis nostra, nomine mutui, super expensis hospitii ipsius consortis nostræ, a prima dominica quadragesimæ proximo præterita usque in quindenam prædictam, per octo septimanas, videlicet, qualibet septimana quinquaginta marcas; et quas in eadem garderoba, ad rogatum nostrum, postmodum solverunt; sicut, per billam dilecti clerici nostri Henrici de Hale, custodis ejusdem garderobæ, etc. T. ut supra.

\section{CLV.}

11 Edw. II. m. 2.-Rex, etc. Liberate de thesauro nostro dilectis mercatoribus nostris Rogero Ardingelli, Dino Forcetti, Francisco Balduch' ac sociis suis, mercatoribus de societate Bardorum de Florentia, vel uni eorum, citra festum Pascha proximo futurum, quadringentas quadraginta et quinque libras et tres solidos, de quibus iidem mercatores satisfecerunt pro nobis, ad rogatum nostrum, dilecto consanguineo et fideli nostro Adomaro de Valencia comiti Pembrokiæ, pro expensis suis, in eundo in nuncium, una cum aliis nunciis nostris solempnibus, ad dominum Summum Pontificem, anno regni 
nostri decimo, prout in quadam billa garderobæ nostræ eidem comiti inde facta, quam idem comes præfatis mercatoribus liberavit, plenius continetur; etc. T. ut supra.

\section{CLVI.}

11 Edw. II. m. 1.-Pro mercatoribus de societate Bardorum.-Rex, etc. Liberate de thesauro nostro dilectis mercatoribus nostris de societate Bardorum de Florentia, vel uni eorum, quadringentas et quinquaginta marcas; videlicet, ducentas marcas, quas iidem mercatores dilecto mercatori nostro Doffo de Barde, qui ad partes proprias profecturus est, pro jocalibus inde emendis et suis amicis dandis; centum libras, quas Rogero Ardingelli, pro laboribus quos sustinuit in negotiis nostris versus curiam Romanam et alibi; et centum marcas, quas Dino Forcetti, pro bono servitio quod nobis impendit et impendet in futurum, concessimus, de dono nostro, in usus proprios pro voluntate sua convertendas — solverunt, per preceptum nostrum, de pecunia prædictæ societatis; quas quidem quadringentas marcas præfatis mercatoribus de societate prædicta, per litteras nostras patentes, concessimus, habendas et percipiendas de primis denariis de decima nobis per clerum provinciarum Cantuariæe et Eboraci nuper concessa provenientibus, seu de aliis exitibus regni nostri. Et, facta liberatione illa, recipiatis ab eisdem mercatoribus, vel uno eorum, litteras nostras supradictas. T. R. apud Wyndesoram, viij die Maii.

\section{CLVII.}

12 Edw. II. m. 3.-Pro mercatoribus de societate Bardorum.-Rex, etc. Liberate de thesauro nostro, citra festum Pentecostes proximo futurum, dilectis mercatoribus nostris Rogero Ardingelli, Dino Forcetti et Francisco Balduch', ac sociis suis, mercatoribus de societate Bardorum de Florentia, quingentas libras, in quibus sibi per litteras nostras patentes tenemur, pro diversis solutionibus per eosdem factis, pro nobis, per mandata nostra diversa, mensibus Septembris, Octobris et Novembris, anno regni nostri duodecimo, sicut per quandam billam, etc. T. R. apud Eboracum, xx die Nobembris.

\section{CLVIII.}

12 Edw. II. m. 2.-Pro mercatoribus de societate Bardorum.-Rex, etc. Liberate de thesauro nostro dilectis mercatoribus nostris Rogero Ardingelli, Dino Forcetti, Francisco Balduchii et sociis suis, mercatoribus de societate Bardorum de Florentia, vel uni eorum, mille marcas, quas nobis, per manus dilecti clerici nostri magistri Johannis Walewayn, nuper thesaurarii nostri, mutuo liberarunt, et quas eis, per litteras nostras patentes, solvere promisimus, bona fide. T. R. apud Eboracum, $x x$ die Februarii. 


\section{CLIX.}

12 Edw. II. m. 1.-Pro mercatoribus de societate Bardorum.-Rex, etc. Liberate de thesauro nostro dilectis nobis Doffo de Barde et sociis suis, mercatoribus de societate Bardorum de Florentia, vel uni eorum, centum libras, pro illis centum libris quas iidem mercatores, ad mandatum nostrum, pro nobis solverunt Egidio de Ispania, de illis centum et octo libris, quatuordecim solidis, quatuor denariis et uno obolo, in quibus sibi tenebamur, tam pro vadiis suis, in rotulo marescalciæ et in guerra nostra Scotiæ, anno regni nostri septimo, quam pro restauro equorum suorum in eadem guerra perditorum, eodem anno. Et, facta liberatione, etc. T. R. apud Eboracum, ix die Junii.

\section{CLX.}

13 Edw. II. m. 3.-Pro Rogero Ardingelli, Bono Philippi, et aliis, etc.-Rex, etc. Liberate de primis denariis provenientibus de decima per clerum Eboracensis diocesis, necnon de duodecima per communitates civitatum et burgorum regni nostri, pro expeditione guerræ nostræ Scotiæ, nobis nuper concessis, dilectis mercatoribus nostris Rogero Ardingelli, Bono Philippi, Dino Forcetti, et Francisco Balduchii et sociis suis, mercatoribus de societate Bardorum de Florentia, vel uni eorum, duo milia marcarum, quæe eis, per litteras nostras patentes, pro bono servitio quod iidem mercatores nobis impenderunt, necnon pro dampnis et expensis quæ sustinuerunt, ratione retardationis solutionum diversarum pecuniæ summarum, nobis per ipsos prius mutuatarum, concessimus, percipienda de denariis prædictis. Et, facta liberatione prædicta, recipiatis a præfatis mercatoribus, vel uno eorum, litteras nostras supradictas. T. R. apud Eboracum, xxij die Januarii.

\section{CLXT.}

\section{Per ipsum Regem.}

13 Edw. II. m. 2.-Pro mercatoribus de Florentia.-Rex, etc. Liberate de thesauro nostro dilectis mercatoribus nostris Rogero Ardingelli, Bono Philippi, Dino Forcetti et Francisco Balduchii, et sociis suis, mercatoribus de societate Bardorum de Florentia, vel uni eorum, in festo $\mathrm{S}$. Martini proximo futuro, de denariis provenientibus de decima cleri Angliæ, ad opus nostrum, per dominum Summum Pontificem imposita jam de novo, vel aliunde, octingentas libras, pro illis octingentis libris quas nuper recepimus de magistro Guillielmo de Balaeto, tunc capellano et nuncio dicti domini Summi Pontificis in Anglia, jam defuncto, per manus dilecti mercatoris nostri Antonii Pessaigne de Janua, et quas dicti mercatores manuceperunt solvere, pro nobis, venerabili patri Rigando electo Wyntoniensi confirmato nuncio dicti domini Summi Pontificis in Anglia, citra festum Omnium Sanctorum proximo jam futurum. Et, facta liberatione prædicta, recipiatis ab eisdem mercatoribus, vel uno eorum, litteras nostras patentes, quas iidem inde habent. T. R. apud Westm. xxv die Aprilis. 


\section{CLXII.}

14 Edw. II. m. 1.-Pro Johanne de Merlawe.-Rex, etc. Allocate Johanni de Merlawe, nuper uni custodum novæ custumæ apud Lenne, et Thomæ de Jernemuth, Thomæ Pleyndamour et Aliciæ quæ fuit uxor Roberti de London', defuncti, executoribus testamenti ejusdem defuncti, qui fuit alter custodum custumæ prædictæ, in compoto suo ad scaccarium prædictum, novem libras et decem solidos, quos iidem custodes, per præceptum domini Edwardi, quondam Regis Angliæe, patris nostri, de exitibus dictæe custumæ, liberarunt Chimino de Bello de Florentia, attornato societatis mercatorum de Friscobaldis de Florentia, anno prædicti patris nostri tricesimo primo; et viginti et duas libras et decem solidos, quos, similiter, per præceptum dicti patris nostri, de exitibus dictæ custuma, liberarunt Bettino de Friscobaldis, mercatori de societate prædicta, anno prædicti patris nostri tricesimo secundo. Nisi prius, etc. Et recipiatis a præfato Johanne et executoribus prædictis brevia dicti patris nostri de præcepto, per quæ prædictam pecuniam liberarunt, necnon et indenturas factas in hac parte. T. R. apud Westm. viij die Maii.

\section{CLXIII.}

14 Edw. II. m. 1.-Pro Bono Philippi et sociis suis.-Rex, etc. Liberate de thesauro nostro dilectis mercatoribus nostris Bono Philippi et sociis suis, mercatoribus de societate Bardorum de Florentia, in festo S. Martini proximo futuro, duo milia marcarum, in partem satisfactionis duorum milium ducentarum et quadraginta librarum, quindecim solidorum, septem denariorum et unius oboli, in quibus nuper tenebamur dilecto consanguineo et fideli nostro Adomaro de Valencia comiti Pembrokiæ, pro vadiis suis et hominum suorum ad arma, ac restauro equorum suorum, in servitio domini Edwardi, quondam Regis Angliæe, patris nostri, in guerra Scotiæ, diversis annis, perditorum, ac pro denariis per eundem Adomarum solutis diversis hominibus peditibus, demorantibus apud Kirkandres et alibi in Scotia, ad vadia dicti patris nostri, inter decimum diem Martii anno regni dicti patris nostri tricesimo quinto, et septimum diem Julii proximo sequentem, prout in quadam billa de garderoba dicti patris nostri, eidem Adomaro inde confecta, plenius continetur: quæ quidem duo milia marcarum præfati mercatores præfato Comiti, pro nobis, solvere manuceperunt, et quæ eisdem mercatoribus, in dicto festo S. Martini, per litteras nostras patentes, solvere promisimus. Et, facta liberatione predicta, recipiatis a prædictis mercatoribus litteras nostras supradictas. T. R. apud Westm. primo die Junii.

\section{CLXIV.}

17 Edw. II. m. 2.-Pro mercatoribus de societate Bardorum de Florentia.-Rex, etc. Liberate de thesauro nostro mercatoribus de societate Bardorum de Florentia mille marcas, quindecim denarios et unum obolum, sterlingorum, pro tribus milibus nongentis

VOL. XXVIII.

$2 \mathrm{~s}$ 
quinquaginta et duo florenis auri de Florentia, quos iidem mercatores, juxta certas conventiones inter nos et ipsos initas, constabulario nostro Burdegalæ, pro negotiis nostris in partibus illis expediendis, liberarunt; non obstante ordinatione seu mandato per nos in contrarium inde factis. T. R. apud Westm. xxvj die Maii.

\section{CLXV.}

17 Edw. II. m. 2.-Pro mercatoribus de societate Scalorum de Florentia.-Rex, etc. Liberate de thesauro nostro mer catoribus de societate Scalorum de Florentia mille marcas, quindecim denarios et un um obolum, sterlingorum, pro tribus milibus nongentis quinquaginta et uno florenis auri de Florentia, quos iidem mercatores, etc. ut supra, de verbo ad verbum. T. R. ut supra.

\section{CLXVI.}

17 Edw. II. m. 2.-Pro mercatoribus de societate de Perruch'.-Rex, etc. Liberate de thesauro nostro mercatoribus de societate de Perruch' de Florentia mille marcas, quindecim denarios et unum obolum, sterlingorum, pro tribus milibus nongentis quinquaginta et uno florenis auri de Florentia, quos iidem mercatores, etc. ut supru, de verbo ad verbum. T. R. ut supra.

\section{CLXVII.}

20 Edw. II. m. 1.-Pro Johanne de Oxendon'--Rex, etc. Liberate de thesauro nostro dilecto clerico nostro Johanni de Oxindon, custodi garderobæ Isabellæ Reginæ Angliæ, consortis nostræ carissimæ, mille trescentas tresdecim libras, sex solidos et octo denarios, ad opus dilectorum mercatorum nostrorum Taldi Valoris et Petri Reinerii, et sociorum suorum, mercatorum de societate Bardorum de Florentia, pro tanta pecuniæ summa per ipsos mutuata præfatæ consorti nostræ, in subventionem expensarum suarum, dum eadem consors nostra nuper in partibus Franciæ, ad custus nostros, moram fecit: præfatum Johannem inde, modo debito, onerantes. T. R. apud Kenilworth, xv die Decembris.

$$
\text { Per ipsum Regem, nunciante Regina. }
$$

\section{CLXVIII.}

1 Edw. III. m. 5.-Pro mercatoribus de societate Bardorum de Florentia.-Rex, etc. Liberate de thesauro nostro dilectis mercatoribus nostris Dino Forcetti et sociis suis, mercatoribus de societate Bardorum de Florentia, vel eorum attornato, in hac parte, duo milia librarum, pro tot denariis per ipsos mutuatis Isabellæ Reginæ Angliæ, matri nostræ carissimæ, super expensis suis, dum moram fecit in partibus transmarinis, ad custus domini Edwardi, nuper Regis Angliæ, patris ncstri ; quam quidem pecuniam eadem 
mater nostra, per manus suas proprias, a præfatis mercatoribus recepit. T. R. apud Westm. viij die Februarii.

\section{CLXIX.}

1 Edw. III. m. 5.-Pro Thoma de Londonia.-Rex, etc. Liberate de thesauro nostro dilecto nobis Thomæ de Londonia, nuper custodi garderobæ Isabellæ Reginæ Angliæ, matris nostræ carissimæ, trescentas et sexaginta libras, sex solidos et octo denarios, ad opus dilectorum mercatorum nostrorum Dini Forcetti et sociorum suorum, mercatorum de societate Bardorum de Florentia, pro tanta pecuniæ summa per ipsos mutuata præfatæ Reginæ, in subventionem expensarum suarum, dum eadem Regina nuper in partibus Franciœ, ad custus domini Edwardi, nuper Regis Angliæ, patris nostri, moram fecit: prefatum Thomam inde, modo debito, onerantes. T. ut supra.

\section{CLXX.}

6 Edw. III. m. 6.-Pro mercatoribus de societate Bardorum.-Rex, etc. Liberate de thesauro nostro dilectis mercatoribus nostris Bartholomeo Barde et sociis suis, mercatoribus de societate Bardorum de Florentia, mille libras, in partem recompensationis dampnorum et jacturarum quæ præfati mercatores sustinuerunt, occasione non solutionum diversarum pecunia summarum nobis per ipsos mutuatarum, quas quidem mille libras eis, per litteras nostras patentes, concessimus, percipiendas super diversis custumis nostris ac medietate decimæ quadriennalis, clero Angliæ per dominum SummumPontificem imposita, et nobis, pro altera medietate, concessa, de dono nostro. Et, facta solutione prædicta, recipiatis a præfatis mercatoribus litteras nostras supradictas, necnon litteras suas acquietantiæ, quæ pro nobis sufficientes fuerint, in hac parte. T.R. apud Waltham, xx die Februarii.

Per thesaurarium.

\section{CLXXI.}

6 Edw. III. m. 5.-Pro mercatoribus de societate Peruch'-Rex, etc. Liberate de thesauro nostro, in festo Nativitatis S. Johannis Baptistæ proximo futuro, dilectis mercatoribus nostris Reinero Perini et sociis suis, de societate Peruch', ducentas quadraginta et duas libras, tresdecim solidos et quatuor denarios, quos ab ipsis mutuo recepimus, per manus venerabilis patris W. Norwicensis episcopi, thesaurarii nostri, et camerariorum nostrorum, pro quibusdam negotiis nostris inde expediendis; et quos præfatis mercatoribus, in dicto festo, per litteras nostras, etc. T. R. apud Waltham Sanctæ Crucis, primo die Martii.

\section{CLXXII.}

6 Edw. III. m. 5.-Pro mercatoribus de societate Bardorum.-Rex, etc. Mandamus vobis quod, de primis denariis ad proximum profrum ad scaccarium nostrum venientibus, solvatis dilectis mercatoribus nostris Jacobo Nicholas, Bartholomeo de Barde et 


\section{4}

\section{Extracts relative to Loans supplied by Italian Merchants}

sociis suis, mercatoribus de societate Bardorum de Florentia, mille marcas, pro tanta summa pecuniæ quam iidem mercatores, pro nobis, solvere promiserunt nunciis nostris, quos ad partes Franciæ et curiam Romanam in proximum missuri sumus; ac pro passagio Alianoræ, sororis nostræ carissimæ, versus partes transmarinas: recipientes a præfatis mercatoribus litteras suas acquietantiæ, quæ pro nobis sufficientes fuerint, in hac parte. T. R. apud Westm. xxj die Martii.

\section{CLXXIII.}

6 Edw. III. m. 3.-De denariis liberatis Roberto Tong, pro negotiis Alianora, sororis Regis, faciendis.-Rex, etc. Liberate de thesauro nostro dilectis mercatoribus nostris Jacobo Nicholas et Bartholomeo Barde, et sociis suis, mercatoribus de societate Bardorum de Florentia, mille sexcentas et triginta et quinque marcas, quas, ad requipitionem nostram, solverunt dilecto clerico nostro Roberto Tong', pro quibusdam negotiis Alianoræ, sororis nostræ carissimæ, faciendis. Et recipiatis a præfatis mercatoribus litteras ipsius Roberti, receptionem dictæ pecuniæ testificantes : ipsum Robertum inde, prout justum fuerit, onerantes. T. R. apud Craumpeden', xxix die Julii.

\section{CLXXIV.}

7 Edw. III. m. 6.-Rex, etc. Sciatis quod mutuavimus dilectis mercatoribus nostris Jacobo Nicholas, Bartholomeo de Barde et sociis suis, mercatoribus de societate Bardorum de Florentia, duo milia librarum, pro expeditione quorumdam negotiorum suorum. Et, ideo, vobis mandamus quod eisdem mercatoribus dicta duo milia librarum de thesauro nostro, sine dilatione, solvatis ; quacumque ordinatione in contrarium facta non obstante : recipientes a præfatis mercatoribus litteras suas obligatorias, per quas iidem mercatores promittant solvere nobis quingentas marcas in instante mense Aprilis, et mille marcas mense Junii proximo sequente, et residuas quingentas marcas mense Julii proximo sequente, pro expensis hospitii nostri. T. R. apud Pontem Fractum, xxij die Martii.

Per ipsum Regem.

\section{CLXXV.}

7 Edw. III. m. 5.-Pro Antonio Bache.-Rex, etc. Cum dilectus mercator noster Antonius Bache nuper octingentas sexaginta et tres libras, septem solidos et octo denarios, nobis, ad rogatum nostrum, per diversos homines mutuari fecisset, et diversa vasa nostra aurea et argentea, ac alia jocalia nostra, in custodia sua existentia, eisdem hominibus, pro denariis illis, usque ad certum diem adhuc venturum, pignorasset; Nos, volentes dictis hominibus de summis ab ipsis, ad opus nostrum, sic receptis satisfieri, vobis mandamus quod præfato Antonio prædictos octingentas sexaginta et tres libras, septem 
solidos et octo denarios, dictis hominibus solvendos, de thesauro nostro solvatis ; quacumque ordinatione in contrarium facta non obstante. Et taliter, in hac parte, vos habeatis quod vasa et jocalia nostra prædicta nullatenus amittamus. T. R. apud Dunolmiam, xviij die Aprilis.

\section{CLXXVI.}

7 Edw. III. m. 4.-Pro mercatoribus de societate Bardorum de Florentia.-Rex, etc. Sciatis quod, pro bono servitio quod dilecti mercatores nostri Jacobus Nicholas et Bartholomeus de Barde, mercatores de societate Bardorum de Florentia, qui jam ad partes proprias, de licentia nostra, sunt redituri, nobis multipliciter impenderunt, concessimus eis centum libras, de dono nostro. Et, ideo, vobis mandamus quod eisdem Jacobo et Bartholomeo dictas centum libras de thesauro nostro liberetis. T. R. apud Norum Castrum super Tynam, quarto die Augusti.

\section{CLXXVII.}

7 Edw. III. m. 1.-Pro mercatoribus de societate Bardorum de Florentia.-Rex, etc. Mandamus vobis quod dilectis mercatoribus nostris Dyno Forsetti et Alexandro de Barde, ac sociis suis, mercatoribus de societate Bardorum de Florentia, trescentas quaterviginti et duodecim marcas, sex solidos et octo denarios, de thesauro nostro solvatis, pro certo numero florenorum de Florentia, quos iidem mercatores nuper, ad requisitionem nostram, solverunt dilecto et fideli nostro Willielmo de Tweng', apud Naples, pro quibusdam negotiis nostris, quæ idem Willielmus penes dilectum consanguineum nostrum Regem Ceciliæ fuerit prosecutus, expediendis : recipientes a præfatis mercatoribus billam, quan iidem mercatores inde penes se habent, sigillo prædicti Willielmi consignatam : illum qui inde onerari debet, onerantes. T. R. apud Marlebergh', viij die Decembris.

\section{CLXXVIII.}

8 Edw. III. m.3.-Pro Antonio Bache.-Rex, etc. Mandamus vobis quod dilecto nobis Antonio Bache sexcentas libras, in quibus ei tenemur, pro tot denariis Arnaldo Garsye, apud Parisias, pro equis ad opus nostrum emendis, nuper mutuatis, de thesauro nostro solvatis : præfatum Arnaldum inde, prout justum fuerit, onerantes. T. R. apud Pontem Fractum, quinto die Julii.

\section{CLXXIX.}

8 Edw. III. m. 2.-Pro mercatoribus de societate Bardorum.-Rex, etc. Mandamus vobis quod dilectis nobis Dino Forcetti et Alexandro de Barde, et sociis suis, mercatoribus de societate Bardorum de Florentia, qui, nuper, ad mandatum nostrum, trescentas 
libras Philippæ Reginæ Angliæ, consortis nostræ carissimæ, apud Notyngham, de dono nostro, solverunt, easdem trescentas libras de thesauro nostro solvi; vel vos, præfati thesaurarie et barones, eisdem mercatoribus de summa prædicta debitam assignationem, in loco competente, sine dilatione, fieri faciatis. T.R. apud Eboracum, xxij die Octobris.

Per ipsum Regem.

\section{CLXXX.}

8 Edw. III. m. 2.-Pro Dino Forcetti.-Rex, etc. Liberate de thesauro nostro dilecto mercatori nostro Dino Forsetti et . . . ., uxori ejus, centum libras, quas eidem uxori concessimus, de dono nostro, in remunerationem grati obsequii ipsius Dini nobis, ante hæc tempora, pluries impensi. T. R. apud Northallerton', xxviij die Octobris.

Per ipsum Regem.

\section{CLXXXI.}

9 Edw. III. m. 4.-Pro Bartholomeo de Barde et Alexandro de Barde, et sociis suis.Rex, etc. Liberate de thesauro nostro dilectis mercatoribus nostris Bartholomeo de Barde et Alexandro de Barde, et sociis suis, mercatoribus de societate Bardorum, viginti et septem libras, octo solidos et decem denarios, quos iidem mercatores solverunt, de precepto nostro, Berengario, custodi duorum leonum et duorum leopardorum nostrorum, apud Turrim nostram Londoniæ existentium, pro vadiis ipsius Berengarii, et sustentatione leonum et leopardorum eorumdem, a festo S. Michaelis proximo præterito usque ad festum S. Hillarii proximo sequens. T. R. apud villam S. Johannis, xxv die Augusti.

\section{CLXXXII.}

9 Edw. III. 2.-Pro Bartholomeo de Barde et sociis suis.-Rex, etc. Liberate de thesauro nostro dilectis mercatoribus nostris Bartholomeo de Barde et sociis suis, mercatoribus de societate Bardorum, viginti marcas, quas ipsi nuper solverunt, ad mandatum nostrum, fratri . . . . [Guidonis] comitis de Namours, ad nos, cum eodem Comite, in Angliam venienti, de dono nostro. T. R. apud Novum Castrum super Tynam, xvj die Novembris.

\section{CLXXXIII.}

10 Edw. III. m. 8.-Pro Alexandro de Barde.-Rex, etc. Attendentes grata obsequia quæ dilectus mercator noster Alexander de Barde, mercator de societate Bardorum, nobis, tam pro honore nostro quam utilitate regni nostri, multipliciter impendit, ac volentes ipsi, ea consideratione, prospicere gratiose, concessimus eidem Alexandro et . . . . uxori ejus, centum libras, de dono nostro. Et, ideo, vobis mandamus quod eidem Alex- 
andro dictas centum libras de thesauro nostro, ad opus suum et dictæ uxoris suæ, liberetis, sicut prædictum est. T. R. apud Walsingham, $\mathrm{x}$ die Februarii.

Per ipsum Regem.

\section{CLXXXIV.}

10 Edw. III. m. 6.-Pro mercatoribus de societate Bardorum.-Rex, etc. Cum, per breve sub privato sigillo nostro, mandaverimus dilectis mercatoribus nostris Bartholomeo de Barde et sociis suis, mercatoribus de societate Bardorum, rogando, quatinus Coro Bonecoursse, mercatori Londoniæ, septem libras, octo solidos et quatuor denarios, in quibus sibi, pro speceria ab eo ad opus nostrum empta, tenebamur, sicut per quamdam billam, sigillo dicti clerici nostri magistri Willielmi de la Zouche, nuper custodis garderobæ nostre, signatam, et penes ipsum Corum remanentem, plenius poterit apparere, et quod dictam billam a præfato Coro, una cum litteris suis patentibus solutionem dictæe pecuniæ testificantibus, reciperent penes ipsos ; ac prædicti mercatores dicto Coro prædictos septem libras, octo solidos et quatuor denarios solverint, virtute mandati et rogaminis nostrorum predictorum, sicut idem Corus, in cancellaria nostra personaliter constitutus, recognovit; Nos, volentes præfatis mercatoribus de summa illa solutionem fieri jubere, prout decet, vobis mandamus quod eisdem mercatoribus dictos decem libras, octo solidos et quatuor denarios, a thesauro nostro, sine dilatione, solvi faciatis : recipientes ab eisdem breve, litteras et billam, supradicta. T. R. apud villam de Sancto Johanne, vj die Julii.

\section{CLXXXV.}

10 Edw. III. m. 6.-Rex, etc. Cum dilecti nobis Bartholomeus de Barde et Petrus Byne, ac socii sui, mercatores de societate Bardorum, nuper, ad requisitionem nostram, solverint personis subscriptis, in obsequium nostrum, ad partes transmarinas, circa quædam negotia nostra, de quibus per nos et consilium nostrum oneratæ exstiterant, transmissis, summas subscriptas; videlicet, Arnaldo de Tibio quadraginta libras, Sandrardo de Aste viginti libras, Egidio de Ispannia sex libras, tresdecim solidos et quatuor denarios, et Thomæ de Kynelyngworthe sex libras, tresdecim solidos et quatuor denarios, super expensis suis, in obsequio supradicto ; Nos, volentes eisdem mercatoribus de summis prædictis satisfieri, ut est justum, vobis mandamus quod eisdem mercatoribus dictos sexaginta et tresdecim libras, sex solidos et octo denarios, de thesauro nostro, sine dilatione, solvatis, vel eis inde competentem assignationem habere faciatis : præfatos Arnaldum, Sandrardum et Egidium, de summis prædictis per ipsos sic receptis, prout justum fuerit, onerantes. T. R. apud villam de S. Johanne, primo die Julii. 


\section{CLXXXV.}

$10 \mathrm{Edw}$. III. m. 6.-Rex, etc. Liberate de thesauro nostro dilectis nobis Bartholomeo de Barde et Petro Byne, ac sociis suis, mercatoribus de societate Bardorum, decem libras, quas, ad requisitionem nostram, solverunt Petro de Brugges, habendas de dono nostro. T. R. apud villam de S. Johanne, secundo die Julii.

$$
\text { Per Regem. }
$$

\section{CLXXXVI.}

10 Edw. III. m. 5.-Pro mercatoribus de societate Bardorum.-Rex, etc. Cum teneamur dilectis nobis Bartholomeo de Barde et Petro de Byne, ac sociis suis, mercatoribus de societate Bardorum, in decem et novem libris et undecim solidis, quos, ad mandata nostra, solverunt diversis cursoribus, pro expensis suis, ad diversas partes in obsequium nostrum missis; Nos, volentes eisdem mercatoribus de summa illa satisfieri, ut est justum, vobis mandamus quod prefatis mercatoribus dictos decem et novem libras et undecim solidos de thesauro nostro, sine dilatione, solvatis. T. R. apud villam S. Johannis, vij die Julii.

\section{CLXXXVII}

10 Edw. III. m. 3.-Pro mercatoribus de societate Peruch'-Rex, etc. Attendentes grata et utilia obsequia quæ dilecti mercatores nostri Johannes Baronshal et Johannes Junctin, ac socii sui, mercatores de societate Peruch', circa felicem expeditionem diversorum negotiorum nostrorum, non absque magnis et sumptuosis laboribus, multipliciter impenderunt; volentesque ipsos mercatores, eo prætextu, gratiose prospicere, in hac parte ; concessimus eisdem mercatoribus quingentas libras, de dono nostro. Ideo vobis mandamus quod eisdem mercatoribus dictas quingentas libras de thesauro nostro, sine dilatione, solvatis, vel eis competentem assignationem, ubi sibi inde celeriter satisfieri poterit, habere faciatis. T. R. ut supra.

\section{CLXXXVIII.}

10 Edw. III. m. 1.-Pro mercatoribus de societate Bardorum.-Rex, etc. Liberate de thesauro nostro dilectis nobis Bartholomeo de Barde et sociis suis, mercatoribus de societate Bardorum de Florentia, centum libras, quas, de mandato nostro, solverunt dilecto clerico nostro Willielmo de Custantin, pro expensis circa funeralia Johannis, nuper comitis Cornubiæ, fratris nostri, inde faciendis. T. R. apud Turrim Londoniæ, $\mathrm{xv}$ die Januarii. 


\section{CLXXXIX.}

11 Edw. III. m. 6.-Pro mercatoribus de societate Bardorum.-Rex, etc. Cum teneamur dilectis mercatoribus nostris Dino Forcetti et Petro Byne, ac sociis suis, mercatoribus de societate Bardorum, in decem milibus librarum, quæ pro nobis solverunt, ad requisitionem nostram, in partibus transmarinis, diversis hominibus, pro diversis arduis et urgentibus negotiis, nos specialiter contingentibus, inde expediendis; Nos, volentes præfatis mercatoribus de summa illa satisfieri, prout decet, vobis mandamus quod eisdem mercatoribus prædicta decem milia librarum de thesauro nostro, sine dilatione, solvatis : neminem inde onerantes. T. R. apud Staunford', $\mathrm{xxx}$ die Maii.

Per breve de privato sigillo.

\section{CXC.}

11 Edw. III. m. 5.-Pro mercatoribus de societate Bardorum.-Rex, etc. Liberate de thesauro nostro dilectis nobis Dino Forcetti et sociis suis, mercatoribus de societate Bardorum de Florentia, centum libras, quas, pro expeditione quorumdam arduorum negotiorum nostrorum, in partibus transmarinis, de quibus per nos specialiter onerati extiterunt, solverunt: de quibus quidem centum libris ipsos mercatores seu quemcumque alium nolumus onerari. T. R. apud Westm. xxx die Augusti.

Per ipsum Regem.

\section{CXCI.}

11 Edw. III. m.5.-Pro mercatoribus de societate Peruch'-_Rex, etc. Cum teneamur dilectis mercatoribus nostris Johanni Barounshel, Johanni Stephani et Thomæ de Peruch', et sociis suis, mercatoribus de societate Peruch', in centum libris, quas de eisdem mercatoribus, per manus dilecti nostri Willielmi de Kildesby, super quibusdam expensis, circa apparatus et alia, naves pro obsequio nostro arestatas contingentia, faciendis, mutuo recepimus; prout, per litteras nostras obligatorias eisdem mercatoribus inde confectas, poterit plenius apparere; Nos, volentes eisdem mercatoribus de summa prædicta satisfieri, prout decet, vobis mandamus quod eisdem mercatoribus dictas centum libras de thesauro nostro solvatis; eo non obstante quod prædicti mercatores litteras ipsius Willielmi, receptionem dictarum centum librarum testificantes, penes se non habent: recipientes a præfatis mercatoribus litteras nostras supradictas. T. R. apud Westm. primo die Septembris.

\section{CXCII.}

11 Edw. 1II. m. 4.-Pro mercatoribus de societate Peruch'--Rex, etc. Liberate de thesauro nostro dilectis mercatoribus nostris Johanni Baronshel et Johanni Junctyn, ac 
sociis suis, mercatoribus de societate Peruch', duo milia librarum, quæ pro nobis in partibus transmarinis solverunt, pro expeditione quorumdam secretorum negotiorum nostrorum, prout plenius nobis constat: de quibus quidem duobus milibus librarum neminem volumus onerari. T. R. apud Westm. xxviij die Septembris.

Per ipsum Regem.

\section{CXCIII.}

11 Edw. III. m. 3.-Pro mercatoribus de societate Peruch'- -Rex, etc. Cum teneamur dilectis mercatoribus nostris Johanni Baronshel, Johanni Stephani et Thomæ de Peruch', ac sociis suis, mercatoribus de societate Peruch', in triginta et quinque milibus librarum, quorum majorem partem nobis solverunt, sicut per diversa memoranda scaccarii et receptæ nostrorum, et alias evidentias quas iidem mercatores penes se habent, poterit plenius apparere, et residuum dictorum triginta et quinque milium librarum certis personis, pro nobis, solvere assumpserunt; prout in litteris nostris obligatoriis, eis inde confectis, plenius continetur ; Nos, volentes præfatis mercatoribus de summa prædicta satisfieri, vos mandamus quod eisdem mercatoribus dicta triginta et quinque milia librarum de thesauro nostro solvi, vel eis inde competentem assignationem, in locis ubi eis inde celeriter satisfieri poterit, habere faciatis : recipientes ab eis litteras nostras obligatorias supradictas. T. R. apud Westm. xv die Octobris.

\section{CXCIV.}

12 Edw. III. m. 9.-Pro mercatoribus de societate Peruch'-Rex, etc. Cum dilecti nobis Johannes Baroncelli et Thomas de Peruch', et socii sui, mercatores de societate Peruch', solverint, de præcepto nostro, quingentas marcas, pro expeditione quorumdam secretorum negotiorum nostrorum, et nos, volentes eisdem mercatoribus de summa illa satisfieri, ut est justum, dictas quingentas marcas præfatis mercatoribus solvere promiserimus, bona fide, nolentes quod aliquis inde oneretur; vobis mandamus quod eisdem mercatoribus prædictas quingentas marcas de thesauro nostro, sine dilatione, solvi, vel eis inde competentem assignationem, ubi sibi inde celeriter satisfieri poterit, habere faciatis : aliquem de eisdem quingentis marcis, ut præmittitur, nullatenus onerantes. Et, facta solutione, etc. T. R. apud Turrim Londoniensem, xviij die Septembris.

\section{CXCV.}

12 Edw. III. m. 9.-Rex, etc. Cum dilecti mercatores nostri Johannes Baroncelli, Johannes Stephani et socii sui, mercatores de societate Peruch', solverint, ad mandatum nostrum, per breve sub privato sigillo nostro, dilecto et fideli nostro Ricardo Talbot, quem nobiscum retinuimus pro guerra nostra Scotiæ, ducentas marcas, de præstito, super vadiis suis, et, per breve sub magno sigillo nostro, dilecto clerico nostro Johanni 
de Watenhull quingentas libras, ad quædam vadia magistris et marinariis navium, quas apud Portesmuth, pro obsequio nostro, congregari mandavimus, inde solvendis, et, de præcepto venerabilis patris Johannis Cantuariensis Archiepiscopi, dilecto et fideli nostro Johanni Luterel viginti et quinque libras, pro expeditione quorumdam secretorum negotiorum nostrorum, ac, per aliud breve nostrum sub magno sigillo nostro, Willielmo Bacon' quinquaginta marcas, super hujusmodi negotiorum expeditione, necnon, per aliud breve sub privato sigillo nostro, dilecto valletto nostro Berengario de Aragonia, custodi leonum et leopardorum in Turri nostra Londoniensi, decem et octo libras, sex solidos et octo denarios, pro vadiis ipsius custodis, et pro sustentatione leonum et leopardorum prædictorum, sicut per litteras acquietantiæ ipsorum Ricardi, Johannis, Johannis, Willielmi et Berengarii, quas iidem mercatores penes se habent, ut asserunt, poterit plenius apparere; Nos, volentes præfatis mercatoribus de summis prædictis satisfieri, vobis mandamus quod, visis brevibus et litteris prædictis, si vobis constare poterit ipsos mercatores dictas pecuniarum summas præfatis Ricardo, Johanni, Johanni, Willielmo et Berengario, in forma prædicta, solvisse, tunc easdem pecuniarum summas præfatis mercatoribus de thesauro nostro, sine dilatione, solvi, vel eis inde competentem assignationem, in locis ubi eis de pecunia prædicta celeriter satisfieri poterit, habere faciatis : recipientes, etc. T. R. apud Eboracum, xxv die Martii.

\section{CXCVI.}

Per ipsum Regem.

12 Edw. 1II. m. 9.-Rex, etc. Supplicarunt nobis dilecti nostri Johannes Baroncelli et Johannes Stephani, ac socii sui, mercatores de societate Peruch', ut, cum teneamur eis in decem et octo libris, quas, per manus Laurentii de Mees et Nicholai Moundelard, nuper collectorum custumarum nostrarum in portu Suthampton', ab eisdem mercatoribus, de decem et octo miliaribus stanni, in navibus per ipsos ibidem carcatis, exinde ad partes exteras ducendis, mutuo recepimus, sicut per litteras nostras patentes sigillo nostro quod dicitur coket signatas, quas iidem mercatores inde penes se habent, ut asserunt, poterit plenius apparere, velimus eis inde solutionem fieri jubere competentem; Nos, volentes præfatis mercatoribus de dictis decem et octo libris satisfieri, ut est justum, vobis mandamus quod, visis dictis litteris nostris de coketto, si vobis constiterit ita esse, tunc præfatis mercatoribus dictas decem et octo libras de thesauro nostro solvi, vel eis inde, etc. ut supra: recipientes, etc. T. ut supra.

\section{CXCVII.}

12 Edw. III. 9.-Rex, etc. Liberate de thesauro nostro dilectis nobis Johanni de Baronshel, Thomæ de Peruch' et Johanni Junctyn, ac sociis suis, mercatoribus de societate Peruch', trescentas viginti et octo libras, quatuordecim solidos et septem denarios, quos liberarunt dilecto nobis Antonio Bache, mercatori, ulterius per ipsum diversis mer- 
catoribus civitatis nostræ Londoniæ, in remunerationem obsequiorum quæ iidem mercatores de civitate prædicta nobis benevole impenderunt, quasdam magnas pecuniarum summas nobis mutuando, et alia urgentia negotia nostra, prout eis injuncta fuerant, prosequendo, solvendas, de dono nostro; vel eisdem mercatoribus nostris competentem assignationem, ubi ipsis celeriter satisfieri poterit, habere faciatis. T. R. apud Novum Castrum super Tynam, xxviij die Martii.

\section{CXCVIII.}

14 Edw. III. m. 2.-Pro Gerardo Bonenseigne et sociis suis, mercatoribus de societate Bardorum.-Rex, etc. Cum nos, considerantes grata et opportuna subsidia quæ dilectus nobis Gerardus Bonenseigne, mercator de societate Bardorum, pluries et benevole nobis fecit, ac affectionem solitam quam in procurandis nostris honore et commodo semper repperimus in eodem, et, proinde, volentes uxorem ipsius Gerardi regiæ liberalitatis gratia prevenire, concesserimus eidem uxori mille marcas, de dono nostro, quas præfato Gerardo, ad opus uxoris suæ prædictæ, plene et integre solvere promisimus, bona fide ; prout in litteris nostris patentibus inde confectis plenius continetur; vobis mandamus quod eidem Gerardo dictas mille marcas, ad opus uxoris suæ prædictæ, de thesauro nostro, sine dilatione, solvatis, juxta tenorem litterarum nostrarum prædictarum. Et, facta solutione illa, recipiatis ab eodem Gerardo litteras nostras supradictas. T. custode prædicto, [Edwardo duce Cornubiæ et comite Cestriæ, filio Regis,] apud Waltham S.Crucis, secundo die Julii.

\section{Per ipsum Regem.}

Consimilia brevia habent mercatores subscripti, de summis subscriptis : videlicet, Bartholomeus de Barde, ad opus uxoris suæ, de quingentis marcis.

Dynus Forcetti, ad opus uxoris suæ, de trescentis marcis.

T. ut supra.

\section{CXCIX.}

16 Edw. III. m. 9.-Pro Petro Byne, uno mercatorum Bardorum.--Rex, etc. Cum, nuper, considerantes bonum et gratuitum servitium nobis per dilectum nobis Petrum Byne, unum mercatorum de societate Bardorum, nobis multipliciter, a longo tempore, impensum, ac volentes, proinde, ipsum Petrum, qui jam ad partes suas proprias, de nostra licentia, est reversurus, prospicere gratiose, concesserimus ei ducentas marcas, pro expensis suis, eundo versus partes supradictas, de dono nostro; prout in litteris nostris patentibus inde confectis plenius continetur; vobis mandamus quod eidem Petro dictas ducentas marcas de thesauro nostro solvatis : recipientes ab eo litteras nostras supradictas. T. R. apud Westm. $\mathbf{x}$ die Aprilis. 


\section{CC.}

18 Edw. III. m. 10.-Pro mercatoribus de societate Bardorum.-Rex, etc. Cum dilecti nobis Dinus Forcetti, Petrus Bini et socii sui, mercatores de societate Bardorum, assumpserint facere nobis chevanciam de duodecim milibus florenorum de scuto, in pretio duorum milium librarum sterlingorum, et eosdem florenos liberare magistro Paulo de Monte Florum, in partibus transmarinis, ad opus nostrum; et nos, volentes securitati eorumdem mercatorum in hac parte providere, eadem duo milia librarum sterlingorum, et, ultra hoc, mille libras sterlingorum, in partem solutionis summarum dictis mercatoribus prius per nos debitarum, eisdem mercatoribus, primo die Decembris, anno regni nostri Angliæ sextodecimo, solvere promiserimus, bona fide; prout in litteris nostris patentibus inde confectis plenius continetur; ac præfati mercatores assignationem de dictis duobus milibus librarum, de dictis tribus milibus librarum, habuerint, et quicquam de residuis mille libris eis nondum assignatum vel solutum existit, sicut dicunt; Nos, volentes eisdem mercatoribus de prædictis mille libris satisfieri, vobis mandamus quod, si vobis constiterit ipsos mercatores dicta duo milia librarum præfato Paulo, ad opus nostrum, solvisse, et eis inde, et non de prædictis mille libris residuis, assignationem seu alias solutionem factam fuisse, tunc eisdem mercatoribus dictas mille libras solvi et habere faciatis, juxta tenorem litterarum nostrarum prædictarum. T. R. apud Westm. xx die Februarii.

\section{CCI.}

20 Edw. III. m. 6.-Pro Johanne Dyny mercatore-—Rex, etc. Liberate de thesauro nostro Johanni Dyny, mercatori, ducentas et quinquaginta libras, pro tot denariis ab eo, ad opus nostrum, mutuatis; et centum et viginti et quinque libras, in partem satisfactionis debitorum in quibus mercatoribus de societate Peruch' tenemur: recipientes, etc. T. R. apud Porcestre, $\mathrm{x}$ die Junii.

\section{CCII.}

20 Edw. III. m. 3.-Rex, etc. Liberate de thesauro nostro Johanni de Stodeye et Danieli Gracerent quatuor milia librarum, pro tot denariis ab eis, ad opus nostrum, mutuatis, et duo milia librarum, in partem satisfactionis debitorum in quibus mercatoribus de societate Peruch' tenemur : recipientes ab eisdem Johanne et Daniele litteras nostras patentes, dictam summam duorum milium librarum continentes. T. ut supra.

\section{CCIII.}

21 Edw. III. m. 4.-Pro mercatoribus de societate Bardorum.-Rex, etc. Liberate de thesauro nostro Dino Forset et sociis suis, mercatoribus de societate Bardorum, duo- 
decim florenos auri de scuto, quos, nuper, in curia Romana, per testimonium dilecti clerici nostri magistri Johannis de Offord, et quorumdam aliorum nunciorum nostrorum, tunc in curia prædicta existentium, cuidam cursori, litteras ipsorum nunciorum nostrorum ab eadem curia usque ad nos in Angliam deferenti, solverunt. T. custode prædicto, [Leonello, flio Regis,] apud Redyng, xxiij die Julii.

\section{CCIV.}

21 Edw. III. m. 2.-Pro mercatoribus de societate Bardorum.-Rex, etc. Mandamus vobis quod dilectis mercatoribus nostris de societate Bardorum centum et quinquaginta libras, in partem solutionis quinquaginta milium quadringentarum quaterviginti et tresdecim librarum, quinque solidorum, duorum denariorum et unius oboli, in quibus eis, per litteras nostras patentes, tenemur, si eisdem mercatoribus tantum de dicta majori. summa adhuc debeatur, de thesauro nostro solvatis. T. R. apud Westm. xvij die Octobris.

\section{CCV.}

26 Edw. III. m. 3.-Pro mercatoribus de Luca.-R. etc. Cum Nicholaus Berthelme et socii sui, mercatores de Luca, quibus in centum et quadraginta milibus parvorum florenorum de Florentia, pretii cujuslibet trium solidorum sterlingorum, et etiam in sexdecim milibus florenorum de scuto, pretii cujuslibet trium solidorum et quatuor denariorum sterlingorum, quæ ad viginti et tria milia sexcentas et sex libras, tresdecim solidos et quatuor denarios, sterlingorum, se extendunt, per quasdam litteras nostras patentes et instrumentum publicum tenebamur, quadraginta milia parvorum florenorum, de dictis centum et quadraginta milibus florenorum de Florentia, nobis remiserint et quietumclamaverint, et, per certificationem vestram et baronum nostrorum de scaccario, in cancellaria nostra factam, est compertum quod novem milia centum quinquaginta et quinque libræ, undecim solidi, novem denarii et unus quadrans, de residuis decem et septem milibus sexcentis sexaginta et sex libris, tresdecim solidis et quatuor denariis, sunt soluti; et nos, consideratione remissionis præedictæ, et pro bono servitio nobis per ipsos, ante hæc tempora, impenso, concesserimus quod quatuor milia trescentæ triginta et tres libræ, sex solidi et octo denarii, qui, tam de octo milibus quingentis et un. decim libris, decem et octo denariis, uno obolo et uno quadrante, quam de dictis decem et septem milibus sexcentis sexaginta et sex libris, tresdecim solidis et quatuor denariis, a retro existunt, præfatis mercatoribus solvantur et assignentur, percipiendi super exitibus custumarum nostrarum; videlicet, duo milia et quingentæ marcæ pro terminis Purificationis beatæ Mariæ et Paschæ proximo præteritis, mille marcæ ad festum Nativitatis $\mathbf{S}$. Johannis Baptistæ proximo futurum, mille libræ ad festum S. Michaelis proximo sequens, et mille libræ ad festa Paschæ et S. Michaelis proximo sequentia, per æquales portiones; et quod litteræ patentes sub magno sigillo nostro fiant de residuis 
quatuor milibus centum sexaginta et sexdecim libris, decem et novem solidis, novem denariis, uno obolo et uno quadrante, prædictis mercatoribus, quam citius commode poterimus, solvendis; et quod dictæ duo primæ litteræ nostræ patentes, quæ, una cum instrumento publico prædicto, in custodia dilectorum et fidelium nostrorum Guidonis de Bryan, Andreæ Aubrey et Johannis Malemayn, civium Londoniensium, usque ad finem terminorum prædictorum, remanere volumus, de summis quas eis ad terminos prædictos solvi contigerit indorsentur; prout in quadam indentura, inde inter nos et dictos mercatores confecta, plenius continetur; Vobis mandamus quod prædicti mercatores prædicta quatuor milia trescentas triginta et tres libras, sex solidos et octo denarios, super custuma prædicta, ad terminos prædictos, assignari et liberari faciatis, in forma prædicta: dictas duas litteras de summis quas eisdem mercatoribus sic assignari et liberari feceritis indorsantes, et easdem litteras, factis plenarie assignatione et solutione dictorum quatuor milium trescentarum triginta et trium librarum, sex solidorum et octo denariorum, ad terminos prædictos, in forma prædicta, ab eisdem mercatoribus recipientes. T. R. apud Westm. primo die Junii.

\section{CCVI.}

26 Edw. III. m. 3.-Pro mercatoribus de Janua.-Rex, etc. Cum teneamur Bartholomeo de Cauvilla, Vincentio de Flisco et Johanni Nouel, mercatoribus de Janua, in duobus milibus et quadringentis marcis, quas, pro quibusdam negotiis nostris inde expeditis, de præcepto nostro solverunt, et nos, volentes dictis mercatoribus de summa prædicta satisfieri, prout decet, decimo die Februarii proximo præterito, concesserimus dictis mercatoribus quod ipsi centum saccos lanæ, in portu Londoniæ seu alibi, prout sibi placuerit, carcare, et lanam illam ad partes Flandriæ, ad stapulam nostram ibidem, absque custuma seu subsidio nobis inde solvendis, traducere valeant, in recompensationem trescentarum et sexaginta et quindecim marcarum de summa antedicta; et residuum summæ illius eisdem mercatoribus vel eorum alicui, videlicet, sexcentas marcas inde in festo Paschæ tunc proximo futuro, et sexcentas marcas in festo S. Michaelis proximo sequente, et quadringentas et viginti et quinque marcas in festo Natalis Domini proximo sequente, et quadringentas marcas in festo $\mathbf{S}$. Michaelis proximo sequente, solvere promiserimus; prout in litteris nostris patentibus inde confectis plenius continetur; Vobis mandamus quod eisdem mercatoribus sexcentas marcas, de termino S. Michaelis proximo præterito, solvatis, juxta tenorem litterarum nostrarum prædictarum. T. R. apud Westm. $\mathrm{xx}$ die Octobris.

\section{CCVIr.}

44 Edw. III. m. 2.-Pro Gerardo Walteri, de denariis solvendis.-Rex, etc. Mandamus vobis quod, receptis penes vos litteris nostris patentibus, per quas tenemur solvere 
Gerardo Walteri de Bardes de Florentia quadringentas et quadraginta et duas libras, octo solidos, duos denarios et unum obolum, et eisdem litteris in recepta scaccarii nostri cancellatis et dampnatis, eidem Gerardo, vel attornatis suis, dictos quadringentas et quadraginta et duas libras, octo solidos, duos denarios et unum obolum, de thesauro nostro solvatis. T. R. apud Westm. xv die Decembris.

\section{cCVIII.}

44 Edw. III. m. 2.-Pro Guio de Gieri, de denariis solvendis.-Rex, etc. Mandamus vobis quod, receptis penes vos litteris nostris patentibus, per quas solvere tenemur Guio de Gieri Makianello trescentas et viginti et octo libras, duos solidos et septem denarios, et eisdem litteris in recepta scaccarii nostri cancellatis et dampnatis, eidem Guio, vel attornatis suis, dictos trescentas et viginti et octo libras, duos solidos et septem denarios, de thesauro nostro solvatis. T. ut supra.

\section{CCIX.}

44 Edw. III. m. 1.-Rex, etc. Mandamus vobis quod, receptis penes vos litteris nostris patentibus, per quas tenemur Alexandro Bartholi de Bardes et Bartholomeo domini Radulphi de Bardes in nongentis viginti et quatuor libris, undecim solidis et decem denariis, nuper, ex mutuo, a præfatis Alexandro et Bartholomeo ad opus Regis receptis, et eisdem litteris in recepta scaccarii nostri, pro exoneratione nostra, cancellatis, præfatis Alexandro et Bartholomeo, vel attornatis suis, dictos nongentas viginti et quatuor libras, undecim solidos et decem denarios, de thesauro nostro solvatis, juxta tenorem litterarum nostrarum prædictarum. T. R. apud Westm. xx die Augusti.

\section{CCX.}

44 Edw. III. m. 1.-Rex, etc. Mandamus vobis quod, receptis penes vos litteris nostris patentibus, per quas tenemur Ascelino Simonetti, mercatori de Luka, in ducentis marcis, nuper, ex mutuo, a præfato Ascelino ad opus Regis receptis, et eisdem litteris in recepta scaccarii nostri, pro exoneratione nostra, cancellatis, præfato Ascelino, vel attornatis suis, dictas ducentas marcas de thesauro nostro solvatis. T. ut supra.

\section{CCXI.}

44 Edw. III. m. 1.-Rex, etc. Mandamus vobis quod, receptis penes ros litteris nostris patentibus, per quas tenemur Jacobo Busdrag' et sociis suis, mercatoribus de Luka, in mille ducentis et sexdecim libris, ex mutuo, a præfatis Jacobo et sociis ad opus Regis receptis, et eisdem litteris in recepta scaccarii nostri, pro exoneratione nostra, cancellatis, præfatis Jacobo et sociis suis, vel attornatis suis, dictas mille ducentas et sexdecim libras de thesauro nostro solvatis, juxta tenorem litterarum nostrarum prædictarum. T. ut supra. 